\title{
Potential for Energy Conservation in the Glass Industry
}

B. A. Garrett-Price

A. G. Fassbender

G. A. Bruno

June 1986

Prepared for the U.S. Department of Energy under Contract DE-AC06-76RLO 1830

Pacific Northwest Laboratory Operated for the U.S. Department of Energy by Battelle Memorial Institute 


\title{
DISCLAIMER
}

This report was prepared as an account of work sponsored by an agency of the United States Government. Neither the United States Government nor any agency thereof, nor any of their employees, makes any warranty, express or implied, or assumes any legal liability or responsibility for the accuracy, completeness, or usefulness of any information, apparatus, product, or process disclosed, or represents that its use would not infringe privately owned rights. Reference herein to any specific commercial product, process, or service by trade name, trademark, manufacturer, or otherwise, does not necessarily constitute or imply its endorsement, recommendation, or favoring by the United States Government or any agency thereof. The views and opinions of authors expressed herein do not necessarily state or reflect those of the United States Government or any agency thereof.

\author{
PACIFIC NORTHWEST LABORATORY \\ operated by \\ BATTELLE \\ for the \\ UNITED STATES DEPARTMENT OF ENERGY \\ under Contract DE-AC06-76RLO 1830
}

\begin{tabular}{|c|c|}
\hline \multirow{3}{*}{\multicolumn{2}{|c|}{$\begin{array}{l}\text { Printed in the United States of America } \\
\text { Available from } \\
\text { National Technical Information Service }\end{array}$}} \\
\hline & \\
\hline & \\
\hline \multicolumn{2}{|c|}{ United States Department of Commerce } \\
\hline & \\
\hline \multicolumn{2}{|c|}{ Springfield, Virginia 22161} \\
\hline \multirow{2}{*}{\multicolumn{2}{|c|}{$\begin{array}{l}\text { NTIS Price Codes } \\
\text { Microfiche } A 01\end{array}$}} \\
\hline & \\
\hline \multicolumn{2}{|c|}{ Printed Copy } \\
\hline & Price \\
\hline Pages & Codes \\
\hline 001-025 & $\wedge 02$ \\
\hline 026-050 & A03 \\
\hline $051-075$ & A04 \\
\hline $076-100$ & A05 \\
\hline $101-125$ & $A 06$ \\
\hline $126-150$ & $\mathrm{~A} 07$ \\
\hline 151.175 & $A 08$ \\
\hline $176-200$ & $\wedge 09$ \\
\hline $201-225$ & $A 010$ \\
\hline $226-250$ & A011 \\
\hline 251.275 & A012 \\
\hline $276-300$ & $A 013$ \\
\hline
\end{tabular}


POTENTIAL FOR ENERGY CONSERVATION

IN THE GLASS INDUSTRY

B. A. Garrett-Price

A. G. Fassbender

G. A. Bruno

June 1986

Prepared for the U.S. Department of Energy

under Contract DE-AC06-76RLO 1830

Pacific Northwest Laboratory

Richland, Washington 99352 


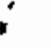

. 
SUMMARY

While the glass industry (flat glass, container glass, pressed and blown glass, and insulation fiber glass) has reduced its specific energy use (Btu/ ton) by almost 30\% since 1972, significant potential for further reduction still remains. State-of-the-art technologies are available which could lead to incremental improvements in glass industry energy productivity; however, these technologies must compete for capital with projects undertaken for other reasons (e.g., capacity expansion, equipment rebuild, labor cost reduction, product quality improvement, or compliance with environmental, health or safety regulations). Narrowing profit margins in the large tonnage segments of the glass industry in recent years and the fact that energy costs represent less than $25 \%$ of the value added in glass manufacture have combined to impede the widespread adoption of many state-of-the-art conservation technologies. Savings in energy costs alone have not provided the incentive to justify the capital expenditures required to realize the energy savings.

Beyond implementation of state-of-the-art technologies, significant potential energy savings could accrue from advanced technologies which represent a radical departure from current glass making technology. Long-term research and development (R\&D) programs, which address the technical and economic barriers associated with advanced, energy-conserving technologies, offer the opportunity to realize this energy-saving potential.

The following summarizes the trends in energy use of the glass industry, the estimated energy-savings potential of current and advanced technologies, and the R\&D opportunities for achieving significant energy savings.

\section{ENERGY USE TRENDS}

The glass industry consumes almost 0.3 quad of energy annually. This represents about $1.0 \%$ of the total energy use of the industrial manufacturing sector. The energy mix in the glass industry consists of about $87 \%$ fossil fuels versus $13 \%$ electricity with natural gas accounting for over $90 \%$ of the fossil fuel use. 
Like other industries, rising fossil fuel prices and short supplies prompted the glass industry to decrease consumption since the early seventies. Energy consumption per ton of product decreased an average of about $27 \%$ between 1972 and 1981. Table S.1 shows the improvement in energy productivity (decrease in specific energy use) over this ten year period for each glass industry segment. Although energy use data for the glass industry are

TABLE 5.1. Glass Industry Energy Productivity Improvement

Container Flat $\underline{\begin{array}{c}\text { Pressed } \\ \text { and Blown }\end{array}} \begin{gathered}\text { Insulation } \\ \text { Fiber }\end{gathered}$ Total

1972:(a)

$\begin{array}{lccccc}\text { Energy Use }\left[10^{12} \text { Btu }\right] & 150.9 & 70.2 & 79.0 & 51.33 & 351.4 \\ \text { Production }\left[10^{6} \text { tons }\right] & 11.9 & 2.71 & 2.04 & 1.64 & 18.29 \\ \begin{array}{l}\text { Energy Productivity } \\ {\left[10^{6} \text { Btu/ton }\right]}\end{array} & 12.7 & 25.9 & 38.7 & 31.2 & 19.21\end{array}$

$1981:(b)$

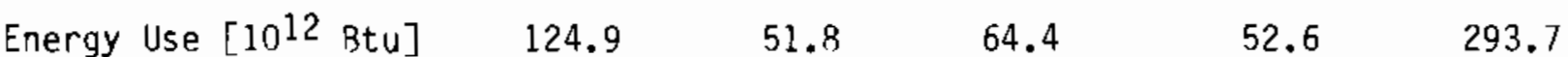

$\begin{array}{llllll}\text { Production }\left[10^{6} \text { tons }\right] & 13.5 & 3.1 & 2.2 & 2.0 & 20.8\end{array}$

Energy Productivity

$\begin{array}{llllll}{\left[10^{6} \mathrm{Btu} / \text { ton }\right]} & 9.3 & 16.7 & 29.3 & 26.3 & 14.1\end{array}$

$\begin{array}{lllllll}\text { Improvement } & 1972-1981 & 21.3 \% & 35.5 \% & 7.5 \% & 15.7 \% & 26.5 \%\end{array}$

$1985:(c)$

Energy Productivity

$\begin{array}{llllll}{\left[10^{6} \text { Btu/ton }\right]} & 9.2 & 14.0 & 20-25 & 18-24 & 12.5\end{array}$

$\begin{array}{llllll}\text { Improvement } 1981-1985 & 1.1 \% & 16.2 \% & 23 \% & 20 \% & 8.7 \%\end{array}$
(a) Schorr 1977.
(b) Calculated from Census of Manufactures 1982 and 1985.
(c) Estimated. 
not available after 1981, estimates of energy productivity for 1985 have been made. These estimates are based primarily on changes in production and assumptions of improvements due to increased capacity utilization. The estimates assume that about a $9 \%$ improvement in average energy efficiency has been experienced by the glass industry in the 1981-1985 period. Low capacity utilization rates in 1981 and 1982 were offset by increased utilization from 1983 through 1985. Closure of older facilities followed by increased capacity utilization in the most efficient facilities are thought to be the dominant factors behind the improvement in energy productivity.

The flat glass and container glass segments have experienced the largest improvements in energy productivity. In flat glass, the improvement is largely a result of abandonment of the energy-intensive plate and sheet processes in favor of the float process. The increased energy productivity of the container glass segment occurred partly through the retirement of older, inefficient facilities. Technologies such as electric boosting, efficient annealing lehrs, improved refractories and insulation, and direct digital process control have all contributed to improved energy efficiency.

Fuel Use

Table S.2 shows the fossil fuel mix in 1972 and in 1981 for each segment of the glass industry. Again, estimates are provided for 1985 based on general industry trends. The glass industry had vertually eliminated its use of fuel oil except as a standby fuel. (Recent decreases in fuel oil prices will most likely reverse this trend.) Due to product quality considerations, the industry remains heavily dependent on natural gas. This is in sharp contrast to other industries in the Stone, Clay and Glass category (cement, lime) that have switched from gas to coal.

Electricity Use

While the overall energy use of the glass industry was decreasing, the ratio of electricity use to total energy use increased from a mean of $8 \%$ to $13 \%$ in the 1972-1981 period. It is estimated that the ratio of electricity use to total energy use in 1985 was about $14 \%$. The industry's greater reiliance on electricity is due to its increased use of electric boosting and all-electric 
TABLE S.2. Fossil Fuel Mix

(Percent)

Flat Glass

Container

Pressed and

Blown

Natural Gas

$\frac{1972}{93} \frac{1981}{95} \frac{1985^{(a)}}{96}$

$\frac{\text { Fuel 0i1 }}{1972 \text { 1981 } 1985^{(a)}}$

$\frac{\text { Other }}{\frac{1972}{6} \frac{1981}{5} \frac{1985^{(a)}}{4}}$

$92 \quad 95 \quad 96$

96

71

$<1$

$<1$

14

4

$\begin{array}{cccc}\text { Blown } & 90 & 93 & 95 \\ \text { Insulation Fiber } & 77 & 88 & 90\end{array}$

95

$\begin{array}{ll}3 & 2 \\ 5 & 1\end{array}$

1

$<1$

$\begin{array}{rrr}7 & 5 & 4 \\ 18 & 11 & 10\end{array}$

\section{(a) Estimated.}

Source: Schorr 1977.

Census of Manufactures 1982.

melting, the use of more automated equipment (substitution of electricity for labor), and increased pollution control equipment.

Electric boosting has become commonplace in the container industry as a means of increasing production rate, but it also saves direct process energy by: 1) introducing energy directly to the melt rather than across the surface of the melted batch, and 2) by eliminating the combustion gases which are a large source of waste heat. All-electric furnaces have been adopted largely by the fiberglass segment due to their reduced emissions, ease of control, and improved product quality. These furnaces are $65 \%$ to $80 \%$ efficient whereas fossil-fired melters are $30 \%$ to $55 \%$ efficient. Although the use of electric melting reduces the direct energy use of the glass industry, the ultimate impact at the utility is an increase in fossil fuel use. When the losses associated with generating and transmitting electricity are taken into account, the efficiency of an electric melter would be on the order of $20 \%$ to $25 \%$.

Although electricity accounts for less than $15 \%$ of the direct energy use in glass-making operations, the cost of electricity accounts for almost onethird of the industry's annual energy bill. Therefore, although most of the industry's conservation efforts to date have focused on fuel use, the greater escalation of electricity costs relative to fuel costs in the near term can be 
expected to lead to a greater emphasis on increasing the productivity of electricity and on the management of plant electricity loads. ENERGY-SAVING POTENTIAL

The most significant opportunities for saving energy are related to melting and fining operations. The amount of energy used in other operations such as batch preparation and handling, forming and post-forming, and product handling is generally very small with respect to the melting step. While a modification to one of these operations may not significantiy change the energy use of that process step, it could have significant impact on the energy used in the melting operation.

The melting/fining step uses $58 \%$ to $85 \%$ of total direct process energy in the flat glass, container glass, and pressed and blown glass segments and $43 \%$ to $51 \%$ in textile and insulation fiber glass processes. Despite the reduction in energy use, the industry still uses an average of almost 4 times the fuel theoretically required (a) to melt a ton of glass. The difference between the theoretical requirement and the fuel actualiy used in 1981 , is estimated to amount to about 120 trillion Btu or about $40 \%$ of the industry's annual energy use. Even the best available technology uses almost 1.5 times the theoretical energy required for melting. Table 5.3 summarizes estimates of the specific energy used in melting for a typical plant, a plant using the best-available technology, and a plant using advanced technology in the near term (by the year 2000) and in the long term (beyond 2000).

TABLE S.3. Comparison of Specific Energy Requirements for Melting (million Btu/ton)

\begin{tabular}{|c|c|c|c|}
\hline & Flat & Container & Insulation \\
\hline Typical: & 7.0 & 6.0 & 6.0 \\
\hline Best Technology: & 5.0 & 4.0 & 5.0 \\
\hline \multicolumn{4}{|c|}{ Advanced Technology: } \\
\hline Near term & 4.5 & 3.5 & 4.0 \\
\hline Long term & 4.0 & 3.0 & 3.0 \\
\hline
\end{tabular}

(a) Theoretical requirement is approximately 2.1 million Btu/ton. 
The adoption of state-of-the-art energy savings technologies is paced by the availability of capital and by the physical limitation of generally having to wait for a furnace rebuild to effect a furnace modification. The fact that the glass industry is not represented by a single trade association or research association, combined with the highly competitive nature of the industry, tends to limit the transfer of technical information on plant experience with specific energy-saving technologies. In addition, furnace designers indicate that in some cases even they have had trouble finding out how well a particular design is operating after installation because many companies regard this as proprietary information.

Table S.4 summarizes the estimated energy-savings potential of current and advanced technologies applicable to the manufacture of glass. Estimates are provided for generic technologies for the near term (the year 2000) and the Tong tem (after 2000). The near-tem potential represents incremental improvements to existing technologies whereas the long-term potential is intended to represent revolutionary breakthroughs in glass making technologies. Realizing the near-term potential may require further development of many of the technologies to reduce costs. Realization of the long-term potential will require undertaking or continuing long-term, high-risk research and development programs.

\section{RESEARCH AND DEVELOPMENT NEEDS}

During the 1970 s and early 1980s, uncertain energy supplies and escalating energy prices provided the glass industry with the incentive to study energy conservation technologies. In recent years, energy prices have stabilized and the long-term outlook for supplies has improved. With the immediate incentives for energy conservation R\&D removed, the glass industry, and in particular the container segment, has reduced it R\&D efforts in this area. (a) Given the current business climate and the high-risk nature of energy conservation R\&D, individual companies are unilkely to support long-range technical efforts in basic technology development which would lead to reductions in energy use

(a) Personal communication with Associated Technical Consultants, Toledo, Ohio. 
TABLE S.4. Estimated Energy-Savings Potential of Incremental and Revolutionary Technologies

\begin{tabular}{|c|c|c|}
\hline Technology & $\begin{array}{l}\text { Industry Savings } \\
\left(10^{12} \mathrm{Btu} / \mathrm{yr}\right)^{(a)}\end{array}$ & $\begin{array}{l}\text { Percent Improvement } \\
\text { (Relative to 1985)(b) }\end{array}$ \\
\hline \multicolumn{3}{|l|}{ Incremental: } \\
\hline Oxygen Enrichment & $20-30$ & $5-8$ \\
\hline Batch Preheating & $20-30$ & $5-8$ \\
\hline Process Control & $6-14$ & $1.5-4$ \\
\hline Improved Refractories & $5-10$ & $1-2.5$ \\
\hline Improved Regenerators & $5-10$ & $1-2.5$ \\
\hline Advanced Burners & $5-10$ & $1-2.5$ \\
\hline \multicolumn{3}{|l|}{ Revolutionary: } \\
\hline Advanced Furnace Concepts & $50-75$ & $13-19$ \\
\hline Advanced Recuperators & $30-70$ & $8-18$ \\
\hline Chemical processing & $20-30$ & $5-8$ \\
\hline Cogeneration & $13-18$ & $3-5$ \\
\hline Lightweighting & $9-18$ & $2.5-4.5$ \\
\hline Advanced Sensors & $10-20$ & $2.5-5$ \\
\hline Advanced Refractories & $10-20$ & $2.5-5$ \\
\hline Advanced Refining Concepts & $5-10$ & $1-2.5$ \\
\hline
\end{tabular}

(a) Based on 1985 estimated production levels. Technologies which reduce power consumption were calculated in terms of primary fuel savings at the utility (i.e., l $\mathrm{kWh}=11,500)$.

(b) Based on 1985 estimated total energy use of 397 trillion Btu, which accounts for electrical conversion and transmission losses.

alone. Private-sector research in the near-term will most likely focus on product development and product quality, and on labor and material saving technologies.

The large tonnage segments of the glass industry (containers and flat glass) have been operating in flat or declining markets. Therefore, it appears unlikely that new glass melting facilities will be built for these segments (with the exception of "mini-float" flat glass facilities). Thus, retrofit 
technologies will likely produce the greatest near-term conservation benefits. Technologies that could only be implemented through construction of new production facilities are not likely to have a significant impact in the near term; however, their gradual implementation over the long term could result in significant aggregate energy savings.

Energy-conservation technologies may be categorized as either evolutionary or revolutionary. Evolutionary technologies represent incremental improvements to existing technologies. Revolutionary technologies represent radical departures from existing technology. R\&D opportunities are discussed below for each of these categories.

Evolutionary Technologies

Incremental technologies which appear to have the greatest near-term potential include oxygen enrichment, glass batch preheating, improved refractories, and computerized control systems. For the most part, the technical feasibility of these technologies has been demonstrated in commercial applications. However, the major barrier to the widespread application of these technologies is their cost. Realization of the energy-savings potential of these technologies may require further $R \& D$ to reduce the costs to a level that will accelerate implementation.

Revolutionary Technologies

Technologies which represent a radical departure from current glass production technology could have a greater impact on the industry's energy productivity than the evolutionary technologies. These technologies are typically in the conceptual or early development stages. Realizing the long-term conservation potential associated with revolutionary technologies will require R\&D programs which address both technical and economic barriers.

Revolutionary technologies which are identified as having significant potential include successful development of an advanced concept glass furnace design, a chemical approach to glass making, a thermochemical recuperator, and product lightweighting technology. An R\&D program aimed at radically changing traditional furnace configurations would represent a long-term, high-risk effort. Although this type of technology would likely have a difficult time 
penetrating the high-tonnage segments of the glass industry in the near term, the long-term benefits could be substantial. Developing a chemical processing method which is technically feasible for large-volume glass production would be another high-risk venture and would require a sustained development effort. Research in chemical processing technology is currently targeted toward production of specialty glass, such as optical glass and noncrystalline solids.

In addition, several technologies (which are considered state-of-the-art technologies in other industries) share a common barrier to adoption by the glass industry: the high temperature, high corrosivity and high fouling potential of the glass furnace exhausts. A basic and applied basic materials research effort aimed at characterizing fouling and corrosion mechanisms and at developing economical materials which can withstand the glass furnace environment would provide the enabling technology for developing thermal recuperators, cogeneration, and advanced sensors.

All of the energy-conserving technologies interact directly or indirectly with the melting process. Their adoption may change the time, temperature, or shear history of the melt. While it is recognized that certain process variables (e.g., combustion temperature, natural convection currents in the glass, and batch blanket coverage) have significant effect on glass quality and process energy use, they are only understood in a qualitative sense. To support technology development, basic research is needed to develop mathematical models of the melt space and the combustion space and the complex interactions between the two. In the near-term, modeling of the combustion space and of energy recovery technologies could be combined to predict system behavior and to optimize technology combinations. In the long term, melt space modeling could provide a predictive tool for analyzing the impact of technology change on glass quality.

Industry cooperation will be essential to the success of any R\&D program. Reliable in-plant measurements will be needed to verify models developed and experienced industry personnel will be needed to bring the perspectives of commercial operations to the interpretation of the model results. 


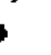

. 
CONTENTS

SUMMARY

iii

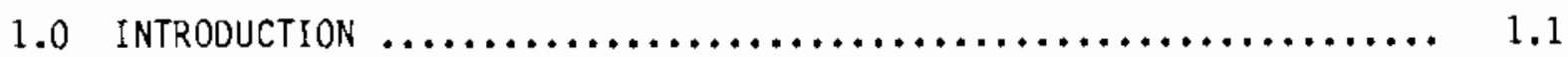

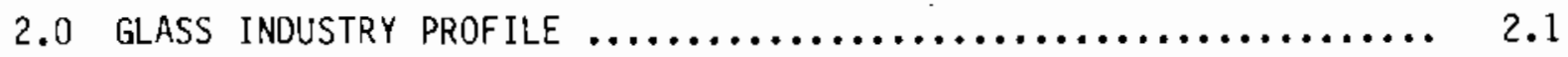

2.1 CONTAINER GLASS $\ldots \ldots \ldots \ldots \ldots \ldots \ldots \ldots \ldots \ldots \ldots \ldots \ldots \ldots, 2.4$

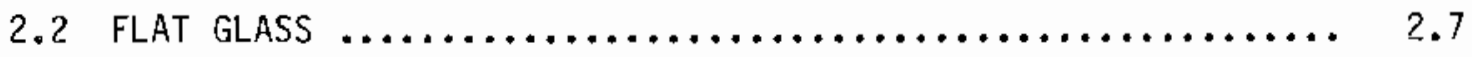

2.3 PRESSED AND BLOWN GLASS $\ldots \ldots \ldots \ldots \ldots \ldots \ldots \ldots \ldots \ldots \ldots, 2.10$

2.4 FIBER GLASS INSULATION $\ldots \ldots \ldots \ldots \ldots \ldots \ldots \ldots \ldots \ldots \ldots \ldots, 2.11$

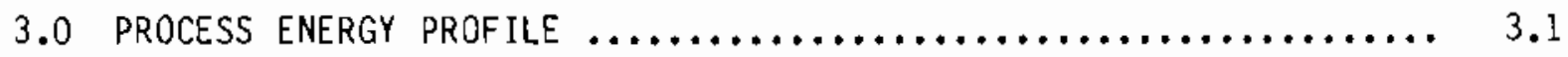

3.1 BATCH PREPARATION AND CHARging $\ldots \ldots \ldots \ldots \ldots \ldots \ldots \ldots \ldots \ldots \ldots \ldots \ldots .4$

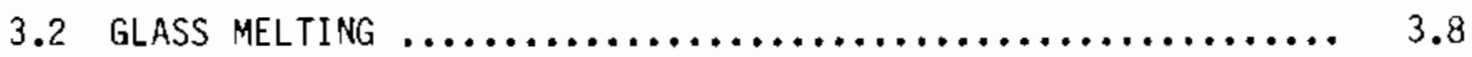

3.2.1 Regenerative Furnaces $\ldots \ldots \ldots \ldots \ldots \ldots \ldots \ldots \ldots \ldots, \quad 3.10$

3.2.2 Unit Melters $\ldots \ldots \ldots \ldots \ldots \ldots \ldots \ldots \ldots \ldots \ldots \ldots, \quad 3.13$

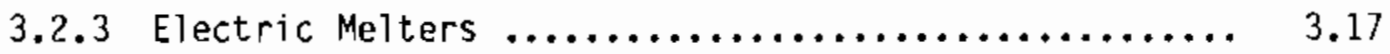

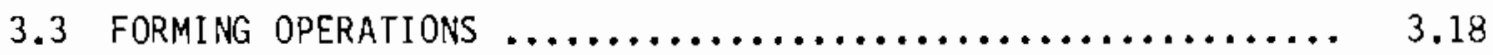

3.3.1 Container Forming $\ldots \ldots \ldots \ldots \ldots \ldots \ldots \ldots \ldots \ldots \ldots, \quad 3.18$

3.3 .2 Flat Glass $\ldots \ldots \ldots \ldots \ldots \ldots \ldots \ldots \ldots \ldots \ldots \ldots \ldots, \quad 3.22$

3.3 .3 Fiberglass $\ldots \ldots \ldots \ldots \ldots \ldots \ldots \ldots \ldots \ldots \ldots \ldots \ldots . ., 3.24$

3.3.4 Other Pressed and Blown Glassware $\ldots \ldots \ldots \ldots \ldots \ldots ., 3.26$

3.4 POST-FORMING OPERATIONS $\ldots \ldots \ldots \ldots \ldots \ldots \ldots \ldots \ldots \ldots \ldots \ldots \ldots \ldots \ldots \ldots \ldots \ldots, 3.28$

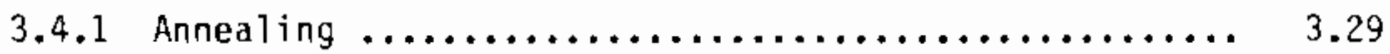

3.4.2 Fiber Drying and Curing $\ldots \ldots \ldots \ldots \ldots \ldots \ldots \ldots \ldots, 3.32$

3.4.3 Tempering and Bending/Tempering $\ldots \ldots \ldots \ldots \ldots \ldots \ldots . . .32$

3.4 .4 Laminating $\ldots \ldots \ldots \ldots \ldots \ldots \ldots \ldots \ldots \ldots \ldots \ldots \ldots \ldots \ldots \ldots \ldots \ldots, 3.35$ 


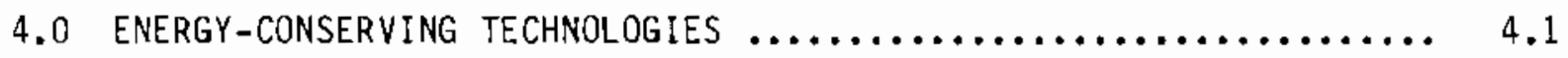

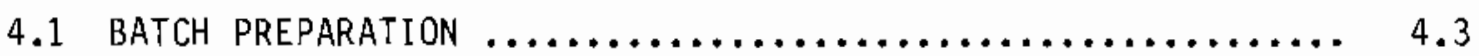

4.2 MeLting $\ldots \ldots \ldots \ldots \ldots \ldots \ldots \ldots \ldots \ldots \ldots \ldots \ldots \ldots \ldots \ldots \ldots, 4.3$

4.2.1 Advanced Melting Concepts $\ldots \ldots \ldots \ldots \ldots \ldots \ldots \ldots, 4.4$

4.2.2 Chemical Boosting $\ldots \ldots \ldots \ldots \ldots \ldots \ldots \ldots \ldots \ldots \ldots, 4.6$

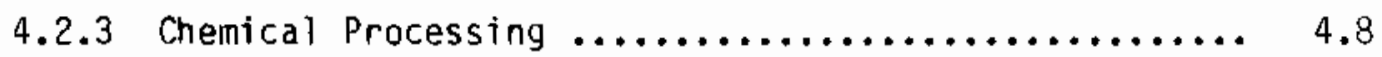

4.2.4 Raw Material Purification ...................... 4.10

4.2 .5 Burner Systems $\ldots \ldots \ldots \ldots \ldots \ldots \ldots \ldots \ldots \ldots \ldots, 4.11$

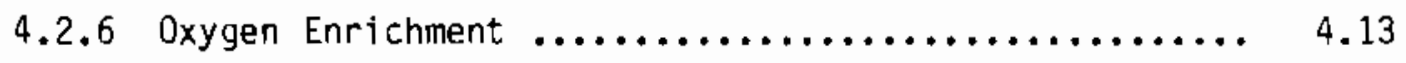

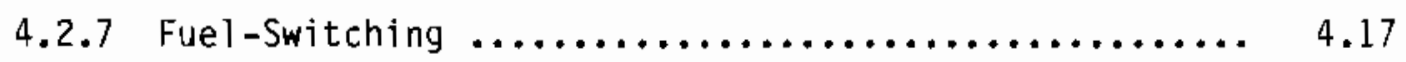

4.2.8 Electric Melting $\ldots \ldots \ldots \ldots \ldots \ldots \ldots \ldots \ldots \ldots \ldots \ldots \ldots \ldots \ldots \ldots, 4.17$

4.2.9 Dual-Depth Melter Design .................... 4.21

4.2.10 Improved Refractories $\ldots \ldots \ldots \ldots \ldots \ldots \ldots \ldots \ldots \ldots, 4.23$

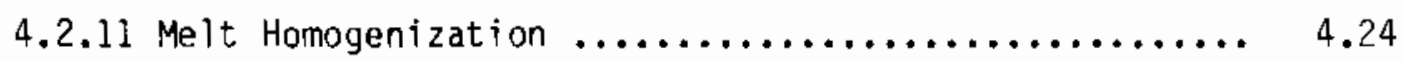

4.3 WASTE-HEAT RECOVERY $\ldots \ldots \ldots \ldots \ldots \ldots \ldots \ldots \ldots \ldots \ldots \ldots \ldots \ldots \ldots \ldots \ldots \ldots \ldots, 4.25$

4.3.1 Glass Batch Preheater ....................... 4.26

4.3.2 Excess Heat Extraction from Regenerators .......... 4.28

4.3.3 Reduction of Regenerator Air Leakage ............ 4.29

4.3.4 Chimney Block Regenerator Refractories ........... 4.31

4.3 .5 Recuperators $\ldots \ldots \ldots \ldots \ldots \ldots \ldots \ldots \ldots \ldots \ldots \ldots \ldots, 4.32$

4.3.6 Thermochemical Recuperator $\ldots \ldots \ldots \ldots \ldots \ldots \ldots \ldots . .6 .35$

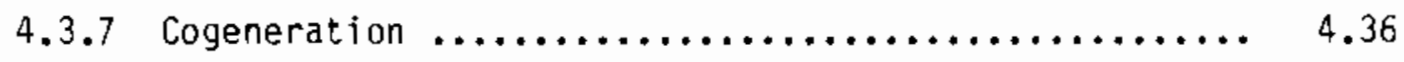

4.4 FORMING AND POST-FORMING $\ldots \ldots \ldots \ldots \ldots \ldots \ldots \ldots \ldots \ldots \ldots \ldots \ldots \ldots \ldots \ldots, 4.40$

4.4 .1 Lightweighting $\ldots \ldots \ldots \ldots \ldots \ldots \ldots \ldots \ldots \ldots \ldots \ldots, 4.41$ 
4.5 PROCESS CONTROL $\ldots \ldots \ldots \ldots \ldots \ldots \ldots \ldots \ldots \ldots \ldots \ldots \ldots \ldots \ldots, 4.44$

4.5.1 Direct Digital Control ....................... 4.44

4.5 .2 0xygen Monitoring $\ldots \ldots \ldots \ldots \ldots \ldots \ldots \ldots \ldots \ldots \ldots, 4.45$

4.5.3 The Superflue Regenerator Flow Controller ......... 4.45

5.0 RESEARCH AND DEVELOPMENT OPPORTUNITIES $\ldots \ldots \ldots \ldots \ldots \ldots \ldots \ldots . . \ldots .1$

5.1 PRIVATE SECTOR RESEARCH $\ldots \ldots \ldots \ldots \ldots \ldots \ldots \ldots \ldots \ldots \ldots \ldots \ldots \ldots \ldots \ldots . \ldots \ldots$

5.2 RESEARCh AND DEVELOPMENT OPPORTUNITIES $\ldots \ldots \ldots \ldots \ldots \ldots \ldots, 5.2$

5.2 .1 Incremental 0pportunities $\ldots \ldots \ldots \ldots \ldots \ldots \ldots \ldots \ldots \ldots, 5.2$

5.2.2 Revolutionary Opportunities .................... 5.3

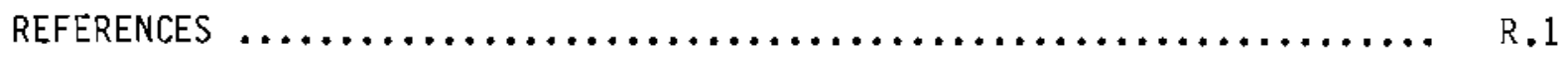

APPENDIX A--ASSUMPTIONS FOR ENERGY-SAVINGS CALCULATIONS $\ldots \ldots \ldots \ldots \ldots$ A.I 


\section{FIGURES}

2.1 Glass Industry Energy Productivity Improvement $\ldots \ldots \ldots \ldots \ldots \ldots .2 .3$

2.2 Direct Energy Cost as a Percent of Direct Production

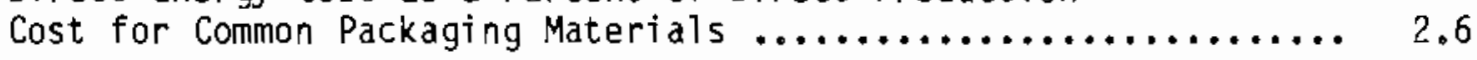

3.1 Flat Glass Production $\ldots \ldots \ldots \ldots \ldots \ldots \ldots \ldots \ldots \ldots \ldots \ldots \ldots \ldots, 3.1$

3.2 Container Glass Production $\ldots \ldots \ldots \ldots \ldots \ldots \ldots \ldots \ldots \ldots \ldots, 3.2$

3.3 Pressed and 81 own Glass Production $\ldots \ldots \ldots \ldots \ldots \ldots \ldots \ldots . . . \ldots \ldots \ldots$

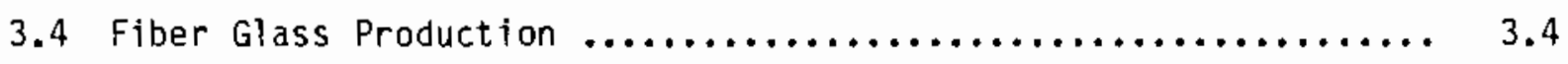

3.5 Side-Port Regenerative Furnace $\ldots \ldots \ldots \ldots \ldots \ldots \ldots \ldots \ldots \ldots \ldots, 3.11$

3.6 End-Port Regenerative Furnace $\ldots \ldots \ldots \ldots \ldots \ldots \ldots \ldots \ldots \ldots \ldots, 3.12$

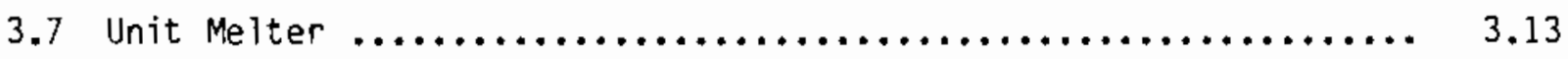

3.8 Double-Shell Metallic Recuperator $\ldots \ldots \ldots \ldots \ldots \ldots \ldots \ldots \ldots \ldots . .15$

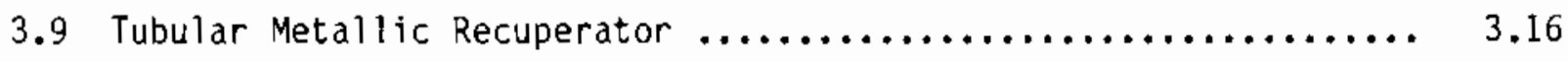

3.10 Energy Use as a Function of Container Weight at Various Production

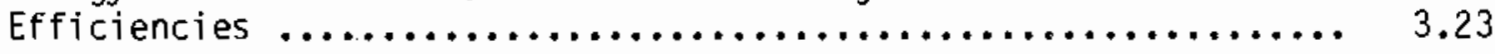

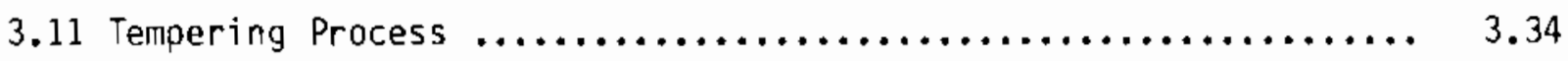

4.1 Sol-Gel Process $\ldots \ldots \ldots \ldots \ldots \ldots \ldots \ldots \ldots \ldots \ldots \ldots \ldots \ldots \ldots \ldots, 4.8$

4.2 Hollow Fiber Oxygen Enrichment System $\ldots \ldots \ldots \ldots \ldots \ldots \ldots \ldots \ldots . .14$

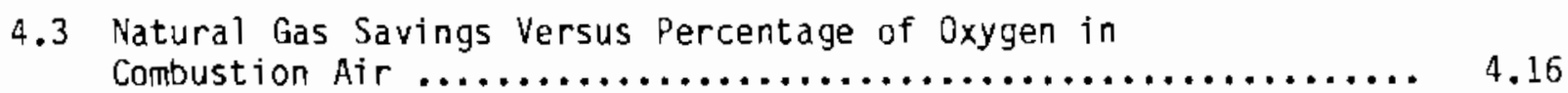

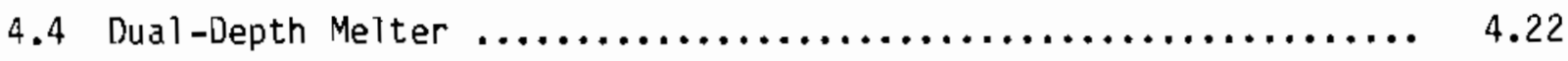

4.5 Fluidized-Bed G1ass Batch Preheater Concept $\ldots \ldots \ldots \ldots \ldots \ldots \ldots . \ldots .27$

4.6 Effect of Air Leakage on Regenerator Performance ............. 4.31

4.7 Fuel Savings Potential of Recuperators $\ldots \ldots \ldots \ldots \ldots \ldots \ldots \ldots .4 .34$

4.8 Heye Glass Melter $\ldots \ldots \ldots \ldots \ldots \ldots \ldots \ldots \ldots \ldots \ldots \ldots \ldots \ldots \ldots ., 4.37$

4.9 Flow Pattern in a Conventional Regenerator $\ldots \ldots \ldots \ldots \ldots \ldots \ldots .4 .46$

4.10 Superflue System $\ldots \ldots \ldots \ldots \ldots \ldots \ldots \ldots \ldots \ldots \ldots \ldots \ldots \ldots \ldots, 4.47$ 


\section{TABLES}

S.1 Glass Industry Energy Productivity Improvement ............. iv

S.2 Fossil Fuel Mix $\ldots \ldots \ldots \ldots \ldots \ldots \ldots \ldots \ldots \ldots \ldots \ldots \ldots \ldots \ldots \ldots$ iv

S.3 Comparison of Specific Energy Requirements for Melting ......... vi

S.4 Energy-Savings Potential of R\&D Opportunities $\ldots \ldots \ldots \ldots \ldots \ldots$...... vii

2.1 Glass Industry Statistics $-1981 \ldots \ldots \ldots \ldots \ldots \ldots \ldots \ldots \ldots \ldots \ldots \ldots \ldots \ldots$

2.2 Glass Industry Purchased Energy $-1981 \ldots \ldots \ldots \ldots \ldots \ldots \ldots \ldots \ldots \ldots$

2.3 Glass Containers: Industry Trends $\ldots \ldots \ldots \ldots \ldots \ldots \ldots \ldots \ldots \ldots$

2.4 1981 Purchased Fuels and Electricity--Container Glass ......... 2.6

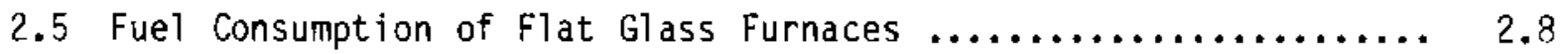

2.6 1981 Purchased Fuels and Electricity--Flat Glass ............ 2.9

2.7 Flat Glass SIC 3211: Historical Shipments and Employment ...... 2.9

2.8 Pressed and Blown Glass--Value of Shipments $1982 \ldots \ldots \ldots \ldots \ldots \ldots$.......

2.91981 Purchased Fuels and Electricity--Pressed and Blown Glass ... 2.11

2.101981 Purchased Fuels and Electricity--Fiberglass Insulation .... 2.12

3.1 Percent of Total Process Energy Consumption by Industry Segment and Process Step ............................ 3.5

3.2 Compositions of Commercial Glass Products $\ldots \ldots \ldots \ldots \ldots \ldots \ldots \ldots$

3.3 Typical Furnace Types and Capacities $\ldots \ldots \ldots \ldots \ldots \ldots \ldots \ldots \ldots . . \ldots$

3.4 Energy Requirements for a Sample of Glass Containers ......... 3.22

3.5 Advantages and Disadvantages of Gas and Electric Lehrs ........ 3.31

4.1 Estimated Energy-Savings Potential of Current and Advanced Technologies ............................... 4.2

4.2 Energy-Conservation Technologies Applicable to Melting ....... 4.4

4.3 Comparison of PSA, Cryogenics and Hol low Fiber Oxygen

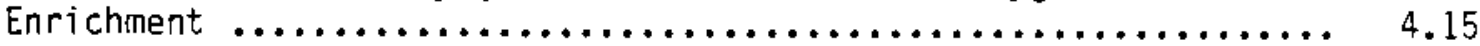


4.4 Melting Experience with the Molybdenum-Lined Melter .......... 4.20

4.5 Typical Air Leakage in Regenerators .................... 4..... 30 


\subsection{INTRODUCTION}

The Office of Industrial Programs (IP) within the U.S. Department of Energy (DOE) contracted Pacific Northwest Laboratory (PNL) to assess the energy conservation potential in six industries. Those six industries are as follows:
- Al uminum
- Pulp and Paper
- Cement
- Steel
- Glass
- Textiles

The information presented in these reports is intended to enable IP to evaluate R\&D opportunities that reflect the current energy and economic environments in which these industries operate.

This report assesses the potential for energy conservation in the glass industry. First, an energy-use profile of the major product sectors of the industry (flat glass, container glass, pressed and blown glass, and insulation fiber) is presented in Chapter 2.0. The energy-use profile is based on 1981 industry production and energy consumption data. This is the last year for which energy data was collected by the Bureau of Census. Projecting use to 1984, based on production, indicates little change in the aggregate energy use of the glass industry. This is followed by a discussion of unit operations and their energy use in Chapter 3.0. This discussion focuses on generic operations found in each industry segment. That is: batch preparation, melting and fining, forming, and post-forming operations. Significant differences in operations and energy use between the processes are identified in each of these four areas. A survey of currently-avajlable and developing energy-conserving technologies is presented in Chapter 4.0. This chapter describes each technology, its energy-savings potential, and possible barriers to its adoption. Finally, Chapter 5.0 provides a discussion of research and development (R\&D) opportunities related to saving energy in glass-making operations. 


\subsection{GLASS INDUSTRY PROFILE}

The glass industry is segmented into four parts: Container Glass, flat Glass, Pressed and Blown Glass, and Glass Fiber Insulation. Table 2.1 provides statistics on employment, value of shipments, and energy purchases for each segment in 1981. Projections of purchased energy to 1984 indicate that while changes have likely occurred in the energy use of individual segments, the net energy use of the glass industry is expected to be very close to its 1981 level.

In terms of total employment, value of shipments, and energy purchases, the container segment of the industry is the largest. This segment accounts for about $42.5 \%$ of the glass industry's energy purchases. The Pressed and Blown Glass segment accounts for about $22 \%$ of overall energy purchases and the Flat Glass and Glass Fiber Insulation segments each account for about $18 \%$ of total purchases.

The glass industry purchased a total of 293.7 trillion Btu of energy in 1981, the last year for which data was collected by the Census of Manufactures.

TABLE 2.1. Glass Industry Statistics -1981 (Census of Manufactures 1982, 1985)

\begin{tabular}{|c|c|c|c|c|}
\hline Segment & $\begin{array}{c}\text { Empl oyment } \\
(1000 \text { workers }) \\
\end{array}$ & $\begin{array}{l}\text { Value of } \\
\text { Shipments } \\
\text { (million \$) } \\
\end{array}$ & $\begin{array}{c}\text { Purchased } \\
\text { Energy } \\
\text { (trillion Btu) }\end{array}$ & $\begin{array}{l}\text { Production } \\
\text { million (tons) }\end{array}$ \\
\hline Flat Glass & 17.3 & $1,656.7$ & 51.8 & 3.1 \\
\hline Glass Containers & 61.0 & $4,926.1$ & 124.9 & 13.5 \\
\hline $\begin{array}{l}\text { Pressed and Blown } \\
\quad \text { Glass }\end{array}$ & 46.4 & $2,765.6$ & 64.4 & $2.2^{(\mathrm{a})}$ \\
\hline $\begin{array}{l}\text { Glass Fiber } \\
\text { Insulation }\end{array}$ & 21.8 & $2,338.6$ & 52.6 & $2.0^{(\mathrm{a})}$ \\
\hline $\begin{array}{l}\text { GLASS INDUSTRY } \\
\text { TOTAL }\end{array}$ & 146.5 & $11,687.0$ & 293.7 & 20.8 \\
\hline
\end{tabular}

(a) Estimated. 
This represents about $1.0 \%$ of the total energy used by the industrial manufacturing sector. Table 2.2 shows the types, quantities, and costs of energy purchased by the glass industry in 1981. Eighty-seven percent of total energy purchases was fossil fuel. Natural gas is the fuel of choice for Anerican glass makers although most have oil-firing capability and occasionally burn oil when the price differential between $0 i 1$ and gas is significant. Natural gas accounts for over $90 \%$ of the fossil fuel used by the glass industry. The remaining fuels, distillate and residual fuel oil and LPG, are primarily used as standby fuels.

The glass industry improved its energy productivity (energy use per unit of production) in the period from 1972 to 1981 as shown in Figure 2.1. The average improvement for all sectors of the glass industry for 1972-1981 was $27 \%$ compared to $20.5 \%$ (Office of Industrial Programs 1983) for all. stone, clay and glass industries during the same period. The improvements have resulted from process changes (e.g., conversion from the plate to the float glass

TABLE 2.2. Glass Industry Purchased Energy--1981

(Census of Manufactures 1982)

\begin{tabular}{|c|c|c|}
\hline Type & $\begin{array}{l}\text { Quantity } \\
\text { (trillion Btu) }\end{array}$ & $\begin{array}{c}\text { Cost } \\
\text { (million }\end{array}$ \\
\hline \multicolumn{3}{|l|}{ Fuel oil } \\
\hline - Distillate & 2.35 & 15.1 \\
\hline - Residual & 0.33 & 1.5 \\
\hline Natural Gas & 239.40 & 842.3 \\
\hline LPG & 0.46 & 2.7 \\
\hline Unspecified & 13.56 & 56.6 \\
\hline Total Purchased Fuels & 256.10 & 918.2 \\
\hline Electricity & $37.64\langle a\rangle$ & 429.4 \\
\hline TOTAL PURCHASED ENERGY & 293.74 & $1,347.6$ \\
\hline
\end{tabular}

(a) Utility losses are not accounted for in this figure (i.e., $3413 \mathrm{Btu} / \mathrm{kWh}$ was used to convert from $\mathrm{kWh}$ to Btu). 


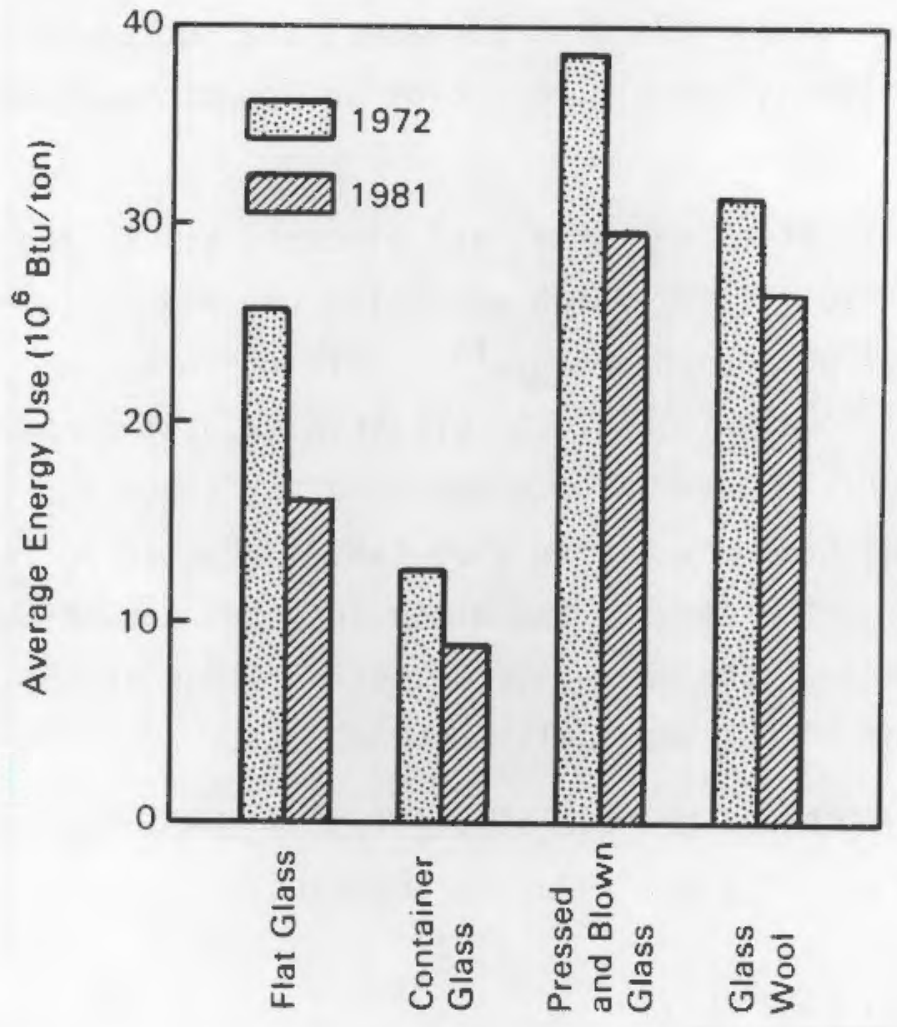

FIGURE 2.1. Glass Industry Energy Productivity Improvement

process), incremental process improvements (e.g., adoption of electric boosting, improved refractories) and plant modernization (retirement of older, lessefficient facilities).

In 1981, electricity accounted for $13 \%$ of the industry's total energy use. All segments of the glass industry have shown gradual increases in the use of electricity relative to fossil fuel. This trend has been most evident in the container glass industry, in which the percentage of total energy use accounted for by electricity has increased from about 9\% in 1972 to almost 13\% in 1981 (derived from Oak Ridge Associated Universities 1980 and Census of Manufactures 1982). The Clean Air Act imposed strict ambient air standards on emissions of suspended particulates, $\mathrm{SO}_{x}$ and $\mathrm{NO}_{x}$ which result from conventional, fossilfired glass melting. This has led to a slight increase in the use of electric melters by the glass industry with the exception of the flat glass sector. 
Besides the adoption of all-electric furnaces, the increasing use of electric boosting, electric lehrs, and air pollution equipment has contributed to this trend.

The average cost of energy (fuel and electricity) to the glass industry was $\$ 4.59 /$ million Btu in 1981 which was below the industrial sector average of $\$ 4.78 /$ million Btu of purchased energy. (a) This reflects the lower portion of the overall energy use attributable to electricity, $13 \%$ compared to $20 \%$ for the manufacturing sector. However, the glass industry's average cost of fossil fuel (\$3.59/ million Btu) was higher than the manufacturing industry average of $\$ 3.20 /$ million Btu. This reflects the glass industry's continued dependence on natural gas when many of the energy-intensive portions of the manufacturing sector have switched to cheaper fuels such as coal.

The following sections provide statistics on the annual production and energy use of each of the glass industry segments.

\subsection{CONTAINER GLASS (SIC 3221)}

This classification includes the production of all types of glass containers used for food and beverages, medicinals, chemicals, and cosmetics.

Due to the high ratio of weight to value added, container glass plants are generally located in proximity to their markets. In general, shipments are restricted to domestic markets. Exports account for less than $1 \%$ of total U.S. production and imports account for less than $2 \%$ of total consumption. The U.S. container industry is composed of approximately 30 firms operating 126 plants in 29 states (Lofquist 1984).

Glass container production in the U.S., the value of shipments in real and nominal terms, and the number of production workers since 1972 are shown in Table 2.3 along with the compound annual growth rate of each of these statistics. The declining value of the industry's shipments (in real terms) and excess industry capacity have combined to force plant closures, layoffs,

(a) Figures calculated from Census of Manufactures 1982. 
TABLE 2.3. Gl ass Containers: Industry Trends (Bureau of Industrial Economics 1984)

$\begin{array}{ccccccc} & 1972 & 1977 & 1981 & 1983 & & \begin{array}{c}\text { Compound } \\ \text { Annual Rate } \\ \text { of Growth } \\ 1972-1983\end{array} \\ \begin{array}{c}\text { Value of Shipments } \\ \text { (million \$) }\end{array} & 2,126.5 & 3,664.2 & 4,926.1 & 5,535.0 & 9.1 \\ \begin{array}{c}\text { Value of Shipments } \\ (1972 \text { million } \$)\end{array} & 2,126.5 & 2,311.8 & 2,024.7 & 1,896.0 & -1.0 \\ \begin{array}{c}\text { Quantity Shipped } \\ \text { (million gross) }\end{array} & 268.0 & 307.0 & 321.0 & 299.0 & 1.0 \\ \begin{array}{c}\text { Production Workers } \\ \text { (000) }\end{array} & 64.5 & 62.5 & 53.4 & 49.4 & -3.2\end{array}$

company mergers and acquisitions, and attempts to maintain market shares through price cutting. These trends are likely to continue in the near term.

Glass containers face competition from other packaging alternatives, such as plastics, paperboard and metal cans. In recent years, the relatively high percentage of the value added in manufacture accounted for by fuel costs has placed the glass industry at a disadvantage with respect to plastic and paperboard containers. Of the common packaging materials, the glass container industry ranks second only to aluminum in direct energy cost as a percent of direct production cost (value added) as shown in Figure 2.2.

The container segment accounts for $42.5 \%$ of the total fuels and electricity purchased by the glass industry. Table 2.4 shows the fossil fuel and electricity purchases for the container glass industry. Fuels account for $87 \%$ of the total energy use, of the container glass segment and electricity accounts for the remaining $13 \%$. Natural gas is by far the dominant fuel, accounting for $95 \%$ of the total fuel purchased by the container glass segment.

The container glass segment experienced a $25 \%$ improvement in energy productivity from 1972 to 1981. This was due in part to the retirement of older, less efficient facilities. In addition, technological changes have included 


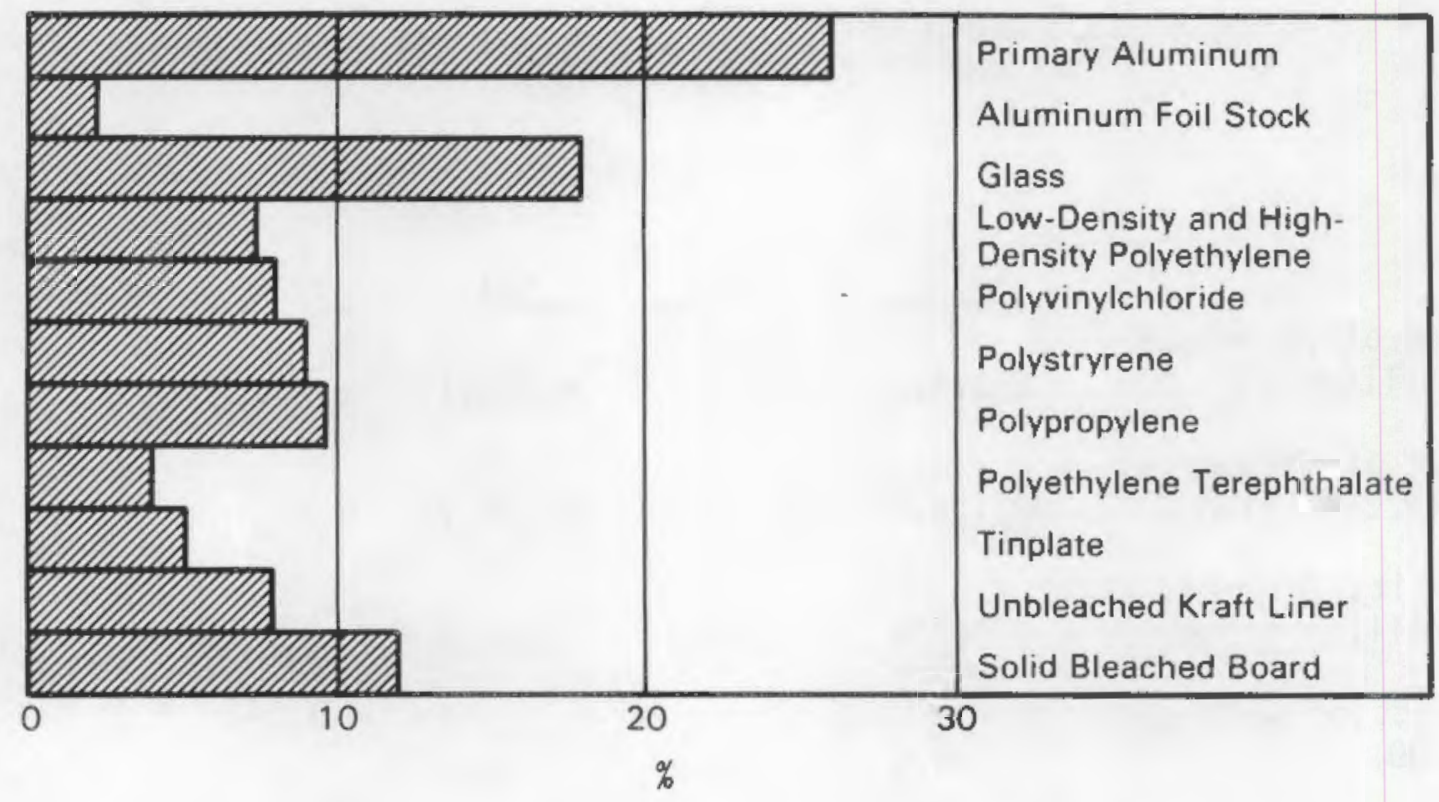

FIGURE 2.2. Direct Energy Cost as a Percent of Direct Production Cost for Common Packaging Materials (Edgington 1984)

TABLE 2.4. 1981 Purchased Fuels and Electricity--Container Glass (Census of Manufactures 1982)

\begin{tabular}{|c|c|c|}
\hline TYPE & $\begin{array}{c}\text { Quantity } \\
\text { (trillion Btu) } \\
\end{array}$ & $\begin{array}{c}\text { Cost } \\
\text { (million \$) } \\
\end{array}$ \\
\hline Distillate Fuel 0il & 1.3 & 8.0 \\
\hline Natural Gas & 103.8 & 373.9 \\
\hline Unspecified & 3.7 & 16.9 \\
\hline Total Purchased Fuels & 108.8 & 398.8 \\
\hline Electricity & $16.1^{(a)}$ & 190.0 \\
\hline TOTAL PURCHASED ENERGY & 124.9 & 588.8 \\
\hline
\end{tabular}

(a) Utility losses are not accounted for in this figure (i.e., $3413 \mathrm{Btu} / \mathrm{kWh}$ was used to convert from $\mathrm{kWh}$ to Btu). 
new glass-forming processes that improve productivity, improved combustion systems, better furnace design, and the use of microcomputers in many phases of the production process.

\subsection{FLAT GLASS (SIC 3211)}

This classification includes the manufacture of flat glass and the fabrication of flat glass into tempered or laminated glass. Products of flat glass include window glass, plate glass, tempered glass, laminated glass, rolled glass and wire glass.

In 1982, 45 companies operated 69 plants that produced flat glass or laminated and tempered glass (Census of Manufactures 1984). Plants include both integrated manufacturers as well as facilities which temper or laminate only. Integrated plants perform the melting and production of flat glass as well as the fabrication of glass products. Nonintegrated companies purchase flat glass from a manufacturer to fabricate glass products.

Integrated flat. glass manufacturers in the U.S. operate 32 flat glass melters. Als but one of these use the float process (Perry 1984). This manufacturer uses the sheet glass process.(a) Currently there are no plate glass producers in the United States. The plate glass process was abandoned because it was both energy - and labor-intensive and because the disposal of the large quantities of slurry produced in the finishing process created an environmental concern. The float glass process uses 60 to $70 \%$ less energy than the plate glass process and 20 to $30 \%$ less energy than the sheet process (Perry 1984). The energy efficiency of the float process can be attributed to its use of larger, more efficient furnaces (see Table 2.5), and to the fact that the glass produced in this process does not require surface finishing which consumes as much as $1000 \mathrm{Btu} / \mathrm{square}$ foot or about $1 \times 10^{6} \mathrm{Btu} / \mathrm{ton}$ (Schorr et al. 1975).

Conversion to the float glass process occurred rather rapidly after its introduction to the U.S. in 1963. At that time, about $51 \%$ of industry capacity produced sheet glass and $49 \%$ produced plate glass. By 1973, the float process dominated with $59 \%$ of the production. Sheet glass accounted for $32 \%$ and plate

(a) Flat Glass Marketing Association, Topeka, Kansas. 
TABLE 2.5. Fuel Consumption of Flat Glass Furnaces

\begin{tabular}{|c|c|c|}
\hline Glass Type & $\begin{array}{c}\text { Furnace Capacity } \\
\text { (tons/day) } \\
\end{array}$ & $\begin{array}{l}\text { Fuel Consumption } \\
\text { (million Btu/ton) }\end{array}$ \\
\hline Sheet & $100-250$ & $12-20(a)$ \\
\hline Plate & $100-300$ & $10-20^{(a)}$ \\
\hline Float & $300-1000$ & $5-11^{(b)}$ \\
\hline
\end{tabular}

(a) Maines 1977 .

(b) Personal communication with Al Garrone, Henry $F$. Teichmann, Inc., Pittsburgh, Pennsylvania, 1985.

glass production had diminished to 9\% (Perry 1984). As mentioned previously, currently only one plant in the U.S. still uses the sheet process, while all others use the float process.

In 1981, the Flat Glass segment purchased 51.8 trillion Btu of fossil fuel and electricity. Energy costs represent $24 \%$ of the value added in this segment. Table 2.6 shows energy purchases by type. Fossil fuel accounts for $92 \%$ of energy purchases and electricity accounts for $8 \%$. Ninety-five percent of the fossil fuel was natural gas. The energy productivity of the flat glass segment improved about 32\% between 1972 and 1981, primarily as a result of conversion to the float process.

The major consumers of flat glass products are the construction and automotive industries. Thus, the health of the flat glass industry is tied closely to these two cyclical markets. Currently, about $72 \%$ of the flat glass produced is used as architectural glass and the remaining $28 \%$ is used in the manufacture of transportation equipment.(a) Table 2.7 provides historical statistics on the industry's shipments and employment. Exports account for about 12 to $15 \%$ of manufacturer's shipments and imports range from about 5 to $7 \%$ of apparent consumption (8ureau of Census 1984).

The industry has been operating with about $20 \%$ excess capacity on a worldwide basis (White 1984). U.S. capacity utilization is expected to renain below

(a) Flat Glass Marketing Association, Topeka, Kansas. 
TABLE 2.6. 1981 Purchased Fuels and Electricity--Flat Glass (Census of Manufactures 1982)

\begin{tabular}{|c|c|c|}
\hline Type & $\begin{array}{l}\text { Quantity } \\
\text { (trillion Btu) }\end{array}$ & $\begin{array}{c}\text { Cost } \\
\text { (million \$) }\end{array}$ \\
\hline Natural Gas & 45.30 & 161.1 \\
\hline LPG & 0.01 & 0.1 \\
\hline Unspecified & 2.24 & 9.1 \\
\hline Total Purchased Fuels & 47.55 & 170.3 \\
\hline Electricity & $4.25^{(a)}$ & 49.2 \\
\hline TOTAL PURCHASED ENERGY & 51.80 & 219.5 \\
\hline
\end{tabular}

(a) Utility losses are not accounted for in this figure (i.e., $3413 \mathrm{Btu} / \mathrm{kWh}$ was used to convert from $\mathrm{kWh}$ to Btu).

TA8LE 2.7. Flat Glass SIC 3211: Historical Shipments and Employment (Census of Manufactures 1985)

\begin{tabular}{|c|c|c|c|c|}
\hline & 1972 & 1977 & 1981 & 1982 \\
\hline $\begin{array}{l}\text { Value of shipments } \\
\text { (million \$) }\end{array}$ & 937.1 & $1,576.6$ & $1,656.7$ & $1,665.5$ \\
\hline $\begin{array}{l}\text { Production Workers } \\
(000)\end{array}$ & 17.0 & 18.5 & 13.8 & 12.0 \\
\hline
\end{tabular}

$80 \%$ through 1985 . The insulating glass, mirror glass and laminated safety glass sectors of the industry are expected to experience moderate growth in the near-term, with architectural, automotive and tempered glass markets experiencing declines or no growth (Glass Industry January 1985). While the overall demand for flat glass products is expected to decline in 1985, several highvalue added products, such as triple glazing and high-transmission and lowemissivity glasses, are expected to experience growth (Glass Reflections March 1985). (a)

(a) Flat Glass Marketing Association, Topeka, Kansas. 


\subsection{PRESSED AND BLOWN GLASS (SIC 3229)}

The pressed and blown glass industry includes facilities primarily engaged in the manufacture of table, kitchen, art, and novelty glassware; lighting and electronic glassware; and textile-type glass fibers. Table 2.8 shows the value of shipments of each of the major products in this classification.

In 1982, the Census of Manufactures reported 331 plants in this classification, operated by 276 companies. These plants range in size and complexity from specialty, hand-blown glass plants with fewer than 20 employees to the large, automated producers of light bulbs and fluorescent tubes.

In 1981, the Pressed and Blown Glass segment used 64.4 trillion Btu of energy as shown in Table 2.9. Fossil fuels represented $87 \%$ of total energy use and electricity represented $13 \%$. Natural gas accounted for over $93 \%$ of the fossil fuel used by this segment.

of all of the glass industry segments, the cost of energy as a percentage of the value added was lowest for this segment at $13.4 \%$. Many of the final products in this industry contain high value materials which would tend to lower this ratio relative to the other sectors.

TABLE 2.8. Pressed and Blown Glass--Value of Shipments 1982

\begin{tabular}{|c|c|c|}
\hline Product & $\begin{array}{c}\text { Value of Shipments (a) } \\
\text { (million \$) }\end{array}$ & $\begin{array}{l}\text { Shipment Weight }(b) \\
\text { (million tons) }\end{array}$ \\
\hline Table, Kitchen, Art & 814.5 & 1.16 \\
\hline \multicolumn{3}{|l|}{ Lighting and Electronic } \\
\hline Glassware & 772.3 & 0.39 \\
\hline Scientific and Industrial & 369.6 & 0.09 \\
\hline Glass Fiber, Textile Type & 809.2 & 0.56 \\
\hline TOTAL & 2765.6 & 2.20 \\
\hline
\end{tabular}

(a) Bureau of the Census 1982 and 1983.

(b) Shipnent weights for the first three were estimated on the basis of shipment values of $\$ 700, \$ 2000$ and $\$ 4000$ per ton, respectively. These values were escalated to 1982 dollars from 1973 values using GNP implicit price deflators from the Department of Commerce presented by Schorr et al 1975. 
TABLE 2.9. 1981 Purchased Fuels and Electricity--Pressed and Blown Glass (Census of Manufactures 1982)

\begin{tabular}{|c|c|c|}
\hline Type & $\begin{array}{c}\text { Quantity } \\
\text { (trillion Btu) }\end{array}$ & $\begin{array}{c}\text { Cost } \\
\text { (million \$) } \\
\end{array}$ \\
\hline Distillate Fuel 0i1 & 0.86 & 5.9 \\
\hline Natural Gas & 51.90 & 176.1 \\
\hline Unspecified & 3.04 & 11.9 \\
\hline Total Purchased Fuels & 55.80 & 193.9 \\
\hline Electricity & $8.60^{(a)}$ & 90.7 \\
\hline TOTAL PURCHASED ENERGY & 64.40 & 284.6 \\
\hline
\end{tabular}
(a) Utility losses are not accounted for in this figure (i.e., $3413 \mathrm{Btu} / \mathrm{kWh}$ was used to convert from $\mathrm{kWh}$ to Btu).

Both technical and economic factors have resulted in an $8 \%$ improvement in energy productivity in the pressed and blown glass segment between 1972 and 1981. This improvement may be partially attributable to the conversion by some manufacturers of borosilicate ovenware to tempered soda lime. While tempering requires additional energy beyond that required for annealed ware, the reduction in melting energy is significant. Other technology improvements which have contributed to improved energy productivity have included the increased use of electric boosting and electric melters; higher cullet ratios; more efficient lehrs; improved refractories and insulation; and higher production efficiencies in forming operations. While many older facilities have shut down, the impact of these closures on energy productivity has been moderate relative to the container segment because the plants tend to be small and because the number of plants in this segment is so large relative to the other segments. While there is competition from substitute materials with some of the products, it doesn't have the industry-wide impact as in the container glass segment.

\subsection{FIBER GLASS INSULATION (SIC 3296)}

Facilities classified in this segment manufacture glass fiber insulation for architectural, industrial, equipment and appliance end uses. 
There are 35 glass fiber insulation plants in the United States (1985 Glass Industry Directory). Plant production capacities vary from 10,000 tons per year to 220,000 tons per year. The major manufacturers of insulation and textile glass fibers are Owens-Corning Fiberglass, Inc.; Manville Service Corporation; Certain-Teed and PPG, Inc.

In 1981, the industry purchased 52.6 trillion Btu of energy. Eighty-three percent was fossil fuel and $17 \%$ was electricity. Table 2.10 1ists the quantity and cost of energy for 1981 by type. The cost of energy represents about $21 \%$ of the value added in manufacture.

Contacts in the industry indicate that the $16 \%$ energy productivity improvement in the insulation glass segment is largely a result of technology improvement and increased production. These improvements have included electric boosting, improved refractories and insulation, and the use of recuperators.

TABLE 2.10. 1981 Purchased Fuels and Electricity--Fiberglass Insulation (Census of Manufactures 1982)

\begin{tabular}{|c|c|c|}
\hline Type & $\begin{array}{c}\text { Quantity } \\
\text { (trillion Btu) } \\
\end{array}$ & $\begin{array}{c}\text { Cost } \\
\text { (million } \\
\end{array}$ \\
\hline \multicolumn{3}{|l|}{ Fuel 0il } \\
\hline - Distillate & 0.19 & 1.2 \\
\hline - Residual & 0.33 & 1.5 \\
\hline Natural Gas & 38.40 & 131.2 \\
\hline LPG & 0.45 & 2.6 \\
\hline Unspecified & 4.53 & 18.7 \\
\hline Total Purchased Fuels & 43.90 & 155.2 \\
\hline Electricity & $\mathrm{B}_{\mathrm{B}} 70^{(\mathrm{a})}$ & 99.5 \\
\hline TOTAL PURCHASED ENERGY & 52.60 & 254.7 \\
\hline
\end{tabular}

(a) Utility losses are not accounted for in this figure (i.e., $3413 \mathrm{Btu} / \mathrm{kWh}$ was used to convert from $\mathrm{kWh}$ to 8 tu). 


\subsection{PROCESS ENERGY PROFILE}

This chapter discusses the major operations in the various glass-making processes and the energy use associated with each operation.

The manufacturing processes for container glass, flat glass, glass fibers and pressed and blown glass are shown in Figures 3.1 through 3.4. Basically, all glass manufacturing processes involve four generic steps: 1) batch preparation, 2) melting and fining, 3) forming, and 4) post forming.

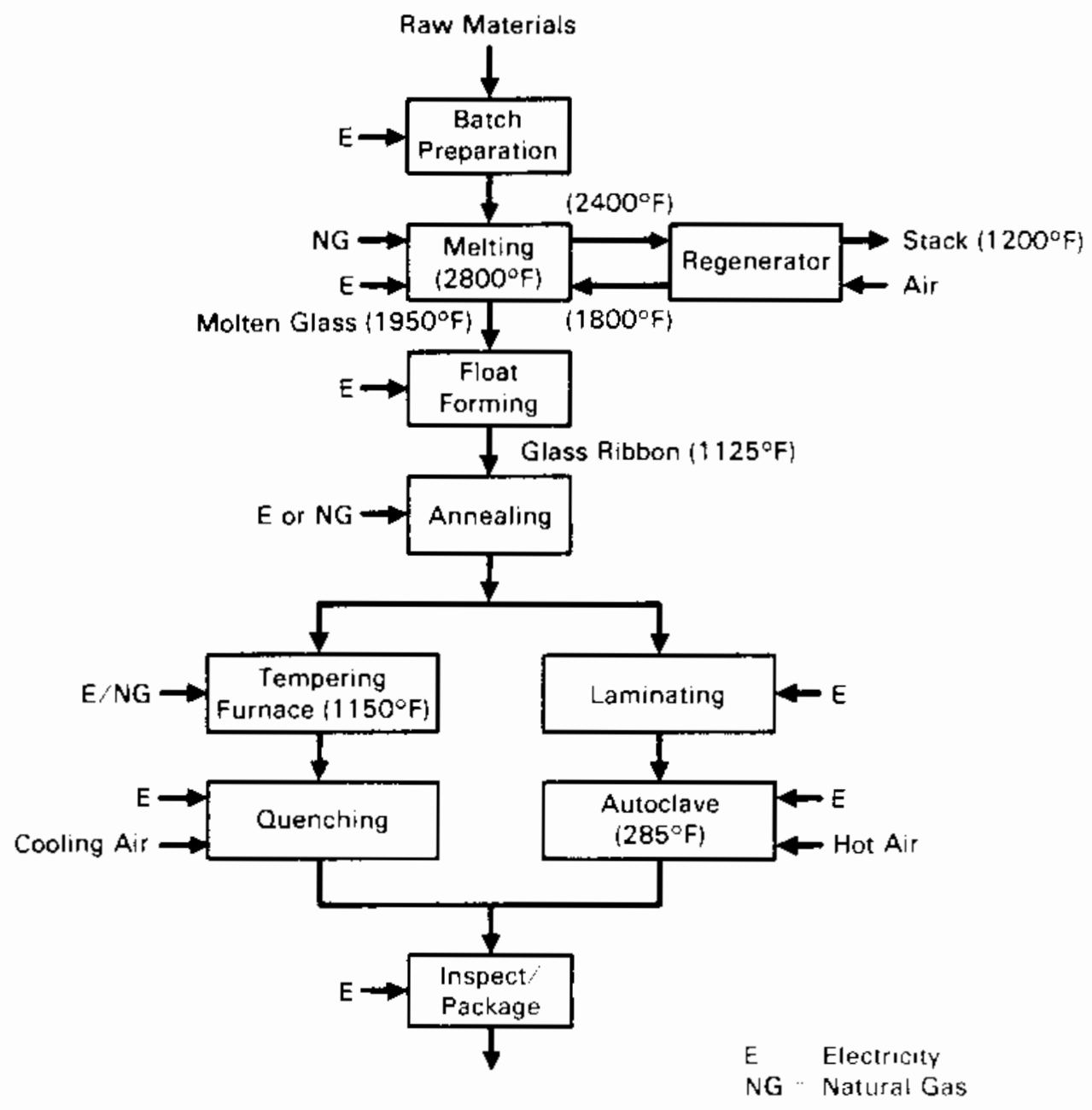

FIGURE 3.1. Flat Glass Production 


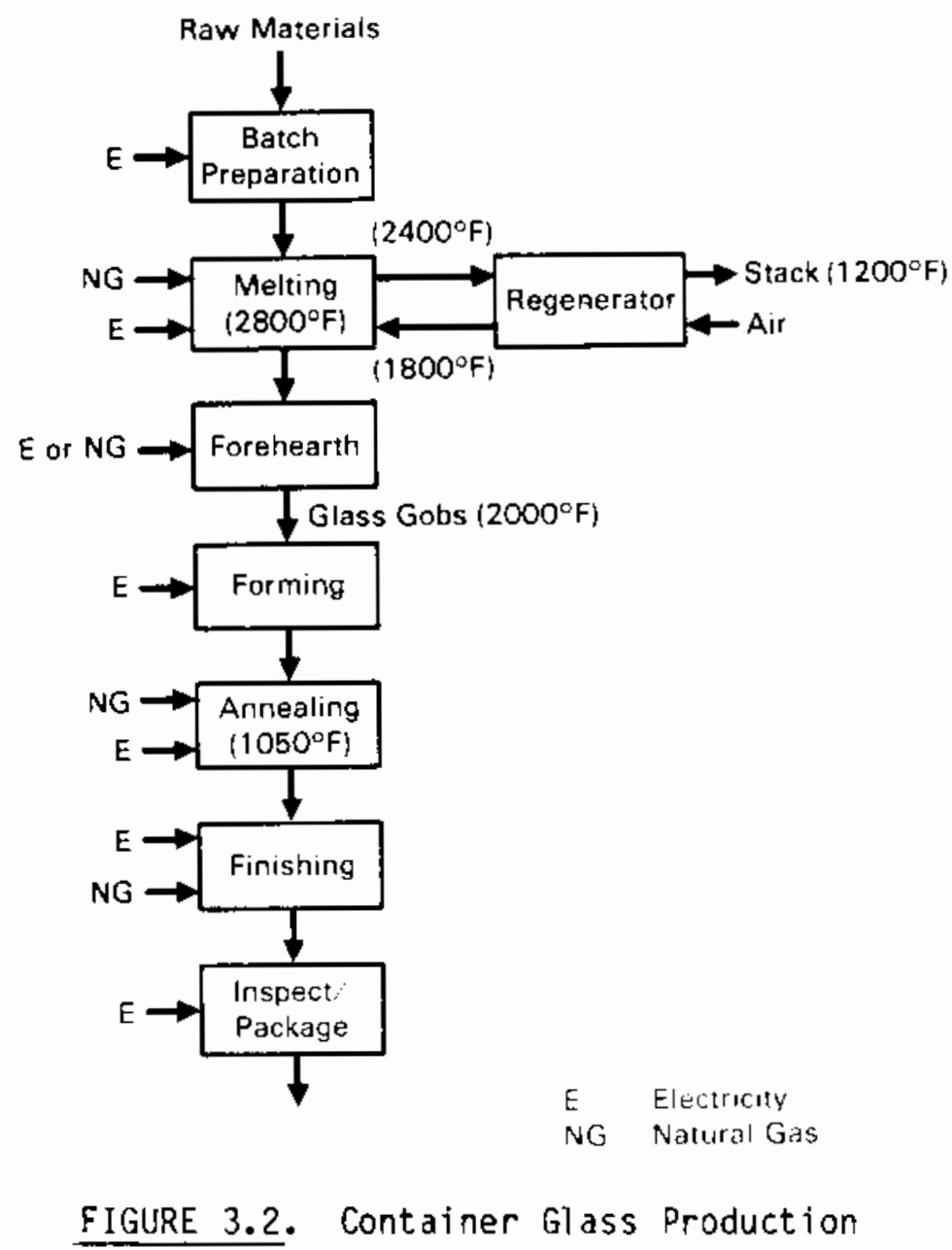

In general, batch preparation involves cullet crushing, mixing and charging the raw materials to the melting furnace. In the furnace, the batch is heated to $2800^{\circ} \mathrm{F}$ to $2900^{\circ} \mathrm{F}$. After melting, gas evolution (fining) occurs near the bridgewall. The glass then flows through the throat to the refiner, or working end, of the furnace. Temperatures are reduced in the refiner to allow reabsorption of any gases not liberated in the melter and to allow thermal and physical homogenization of the glass before it flows through the forehearth to the forming equipment.

Forming and post-forming operations vary widely among the industry segments. However, all glass products, with the exception of glass fibers, are annealed after forming. Following annealing, some flat glass is tempered or laminated. In the container and pressed and blown glass industries, a number 


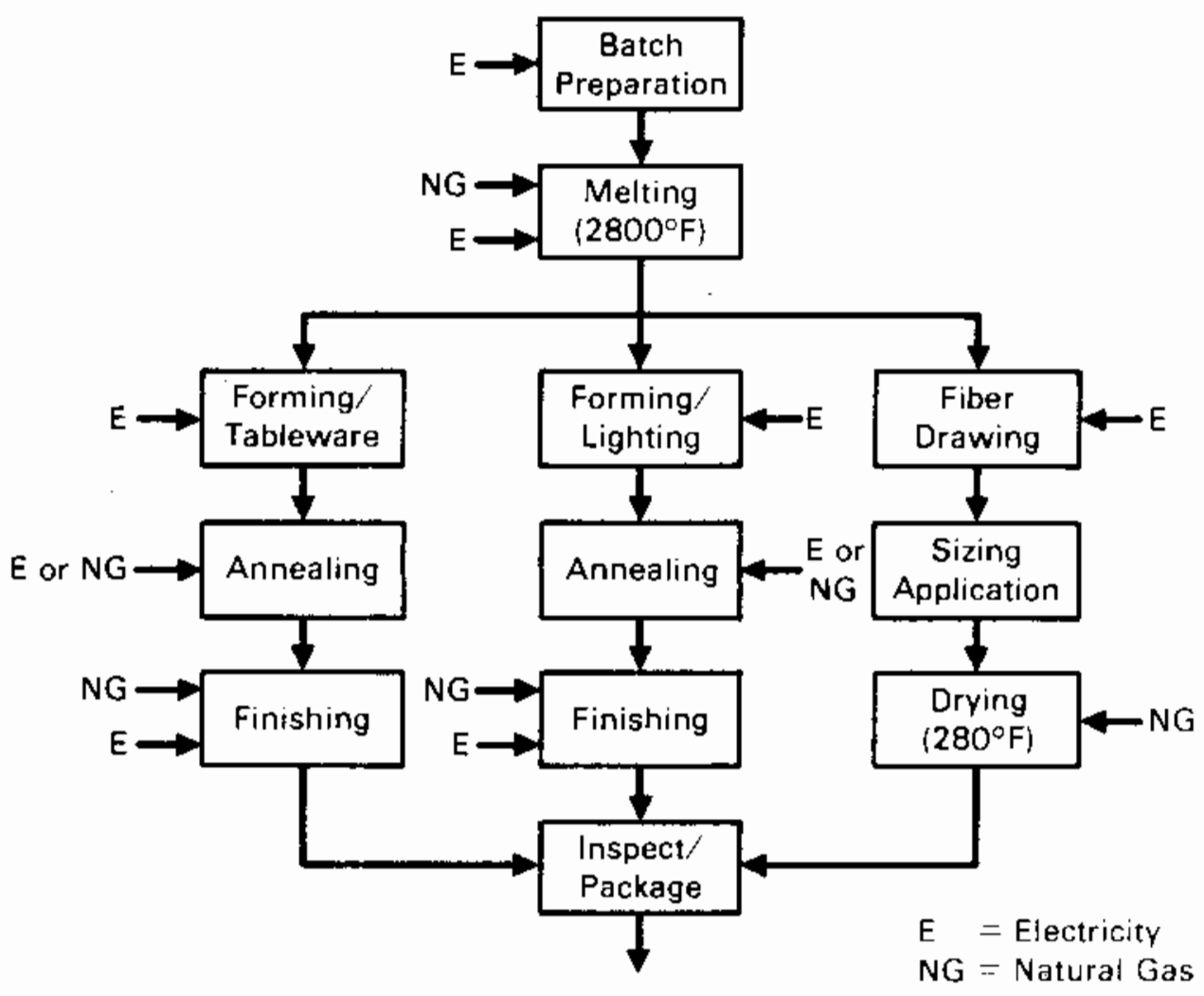

FIgURE 3.3. Pressed and Blown Glass Production

of surface treatments (e.g., decorating, etching, polishing, or coating) may be applied to the annealed ware. Glass fibers are formed, collected, coated with a binder (insulation fibers) or a sizing chemical (textile fibers), and cured or dried in an oven.

Melting is by far the greatest energy consuming operation, accounting for 43 to $85 \%$ of the total process energy use. Table 3.1 shows the percentage of total process energy used by each of the four basic operations plus product handling for each of the industry segments.

The following sections discuss the four generic glass-making operations and their energy use. Significant differences in operations and energy use between the various glass industry segments are discussed in each section. 


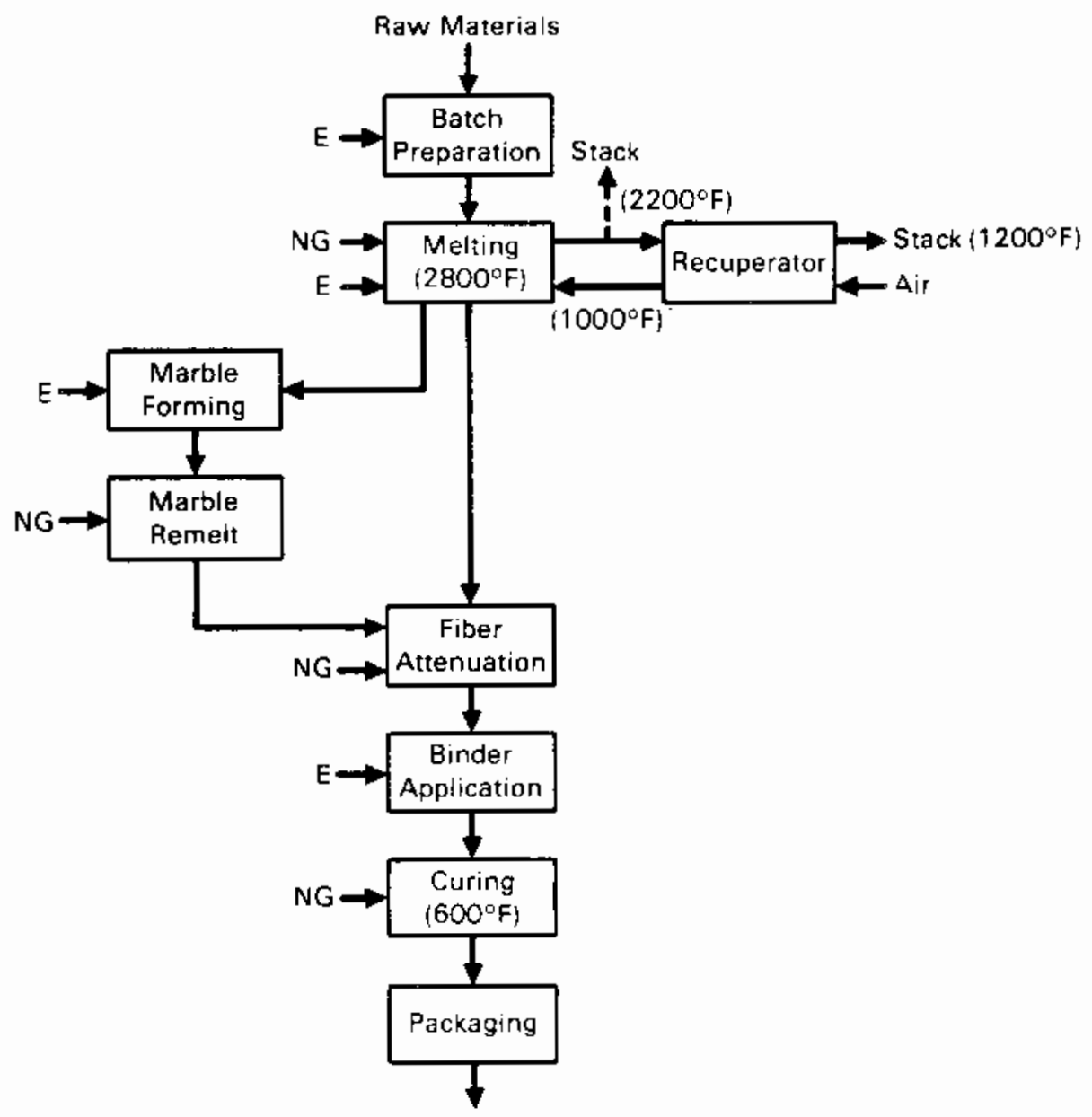

E Electricity
NG Natural Gas

FIGURE 3.4. Fiber Glass Production

\subsection{BATCH PREPARATION AND CHARGING}

The main raw materials used to make glass are silica sand, soda ash, limestone and cullet. Table 3.2 shows the typical chemical composition of the major commercial glasses. Over $80 \%$ of the glass tonnage produced in the United States is some form of soda-lime glass. This includes containers, float glass, light bulbs, and fluorescent tubing. The other main glass composition is borosjlicate glass, which includes any glass containing at least 5 wt $\%$ boron oxide 
TABLE 3.1. Percent of Total Process Energy Consumption by Industry Segment and Process Step $(a)$

\begin{tabular}{|c|c|c|c|c|c|}
\hline Segment & $\begin{array}{l}\text { Batch } \\
\text { Handling }\end{array}$ & $\begin{array}{l}\text { Melting and } \\
\text { Fining }\end{array}$ & Forming & $\begin{array}{l}\text { Post } \\
\text { Forming }\end{array}$ & $\begin{array}{l}\text { Product } \\
\text { Handl ing }\end{array}$ \\
\hline Flat Glass & 1.0 & 85.0 & 5.0 & 8.0 & 1.0 \\
\hline Containers & 2.0 & 73.5 & 12.0 & 10.0 & 2.5 \\
\hline \multicolumn{6}{|c|}{ Pressed and Blown } \\
\hline Hand Ware & 0.5 & 77.0 & 11.0 & 10.5 & 1.0 \\
\hline Machine Ware & 2.0 & 58.0 & 16.5 & 21.5 & 2.0 \\
\hline $\begin{array}{l}\text { Lighting/ } \\
\text { Electronic }\end{array}$ & 1.0 & 67.0 & 14.5 & 15.5 & 2.0 \\
\hline \multicolumn{6}{|l|}{ Glass Fibers } \\
\hline Textile & 2.2 & 51.0 & 32.0 & 11.5 & 3.3 \\
\hline Wool & 2.0 & 43.0 & 40.0 & 13.0 & 2.0 \\
\hline
\end{tabular}

(a) Values presented by Miller 1982 were modified with information received from industry contacts and with assumptions on energy-use trends in each industry segment. Energy requirements for space heating have been excluded, and the energy requirements of the remaining five process steps have been normalized to $100 \%$.

(McLellan 1984). Borosilicate glass products include insulation wool, textile and reinforcing fibers, and low-expansion ovenware such as Pyrex. (a)

Batch preparation and charging involve receiving and storing raw materials, weighing, mixing and conveying operations. Combined, these operations typically account for less than $3 \%$ of total plant energy use. The batch mixer or blender is the single largest energy user in batch operations at a glass plant. Glass plants use various devices such as bucket elevators, screw conveyors, conveyor, conveyer belts and pneumatic conveyers to handie glass batch raw materials.

Cullet is crushed to a general size range before being mixed with the batch. The sieving, and size reduction if necessary, of the other batch components is usually done by the supplier at the point of raw material production.

(a) Pyrex is a trademark of the Corning Glass Company. 
TA8LE 3.2. Compositions of Commercial Glass Products (weight \%) (Pollock 1984)

\begin{tabular}{|c|c|c|c|c|c|c|c|c|c|}
\hline \multirow[b]{2}{*}{ Constituents } & \multirow[b]{2}{*}{ Clear Float } & \multirow[b]{2}{*}{ Container } & \multirow{2}{*}{\multicolumn{2}{|c|}{ Fiber }} & \multicolumn{2}{|c|}{ Glass-Ceramic } & \multirow{2}{*}{$\begin{array}{l}\text { Boro- } \\
\text { Silicate } \\
\text { Labware } \\
\end{array}$} & \multirow[b]{2}{*}{$\begin{array}{c}\begin{array}{c}\text { Ion- } \\
\text { Exchange }\end{array} \\
\end{array}$} & \multirow[b]{2}{*}{$\begin{array}{l}\text { Sodium- } \\
\text { Silicate }\end{array}$} \\
\hline & & & & & $\begin{array}{c}\text { Cooking- } \\
\text { Ware }\end{array}$ & $\begin{array}{l}\text { Cook- } \\
\text { Top }\end{array}$ & & & \\
\hline $\mathrm{SiO}_{2}$ & $72.5-73.4$ & $71.5-73.5$ & 54.0 & 59.0 & 70.0 & 72.0 & 81.0 & 62.2 & 76.0 \\
\hline $\mathrm{B}_{2} \mathrm{O}_{3}$ & & & 10.0 & 3.5 & & & 13.0 & & \\
\hline $\mathrm{Al}_{2} \mathrm{O}_{3}$ & $0.1-1.4$ & $1.3-2.3$ & 14.0 & 4.5 & 18.0 & 19.0 & 2.0 & 17.6 & \\
\hline $\mathrm{Na}_{2} \mathrm{O}$ & $12.7-14.0$ & $12.4-15.6$ & 0.5 & 11.0 & & & 4.0 & 13.1 & 24.0 \\
\hline $\mathrm{k}_{2} \mathrm{O}$ & $0-0.6$ & $0-2.9$ & 0.5 & 0.5 & & & & 3.3 & \\
\hline $\mathrm{MgO}$ & $3.3-4.9$ & $0-1.0$ & 4.5 & 5.5 & 3.0 & 2.0 & 3.2 & & \\
\hline $\mathrm{Fe}_{2} \mathrm{O}_{3}$ & $0.06-0.16$ & & & & & & & & \\
\hline $\operatorname{ZnO}$ & & & & & 1.0 & 1.0 & & & \\
\hline $\mathrm{SO}_{3}$ & $0.17-0.38$ & $0.08-0.22$ & & & & & & & \\
\hline
\end{tabular}


The size distribution of these other raw materials is important to the glass melting process but the actual separation of the raw materials is not part of the glass manufacturing process.

Glass companies take great care in the formulation and mixing of their glass batch. There are differing opinions among furnace operators regarding the benefits of using fine batch materials. The fine batches, 200 to 300 mesh, are more susceptible to entrainment in the flue gas and subsequent carry over into the regenerators. In time, this leads to greater wear of the regenerators, reduced furnace 1 ife and reduced furnace performance. In general, most glasses are made from the lowest cost materials available. Slags from copper and steel production are commonly used in many types of container glass and in some glass wools.

Most furnace operators consider a well-blended batch to be critical to glass melting and subsequent forming processes. If there are inhomogeneities in the batch, melting times may be increased and product quality problems may arise. Chemical inhomogeneities will cause viscosity differences in the glass. The forming operations, whether bottle, flat or fiber, are not designed to compensate for nonuniformities in the glass. For example, if a gob of molten glass has a lower viscosity on one side, the glass will not flow evenly when the bottle is blown. The result will be a thin side of the bottle and an unacceptable product.

Water is usually added to the batch in the blending process. This binds the mass together thereby reducing dusting in the furnaces and helps to prevent segregation of mixed batch. Another benefit of charging wetted batch is the creation of batch logs by the mechanical action of the batch charger (Davis 1985). The wetted batch tends to stick together and form uniform batch logs that float out onto the surface of the melt. Sometimes water is added to the batch for additional dusting and carry over control. The amount of water added is usually around $4 \mathrm{wt} \%$. This water must be evaporated in the furnace. In a 200-ton-per-day furnace, this amounts to eight tons of water being evaporated at an energy penalty of at least $0.09 \mathrm{million}$ Btu/ton glass. If the furnace were feeding $100 \%$ batch (no cullet), the energy penalty could be as high as 0.15 milition Btu/ton. 
Glass batch is delivered to the surface of the melt. Batch is charged on the end of side-port furnaces and on the side of end-port furnaces. The distribution of the batch on the surface is an important factor affecting the heat transfer to the melt. The goals in batch charging are to distribute the batch uniformly across the melt and to avoid allowing partially melted material to flow into the refining zone.

The specific effects of different formulations on the properties of the glass is a subject that has received great study. The use of cullet results in energy savings due to its lower melting point and there is no sensible heat loss due to $\mathrm{CO}_{2}$ evolution. The theoretical melting energy of cullet is about $30 \%$ less than batch, or about 1.5 million Btu/ton. The use of cullet as a percentage of the furnace feed has been increasing in recent years. While cullet loads as high as $80 \%$ of total furnace feed have been demonstrated, cullet usage in the 20 to $30 \%$ range is more common.

Another useful glass ingredient is blast furnace slag. This material is made up of the oxides of silicon, aluminum and calcium. It is used to improve the melting characteristics of the glass, for glass redox control and to replace some or all of the feldspar. The use of blast furnace slag is limited by its sulfur and iron content and the product glass specifications (Ahmed 1985). The use of blast furnace slag is well known to U.S. industry.

\subsection{GLASS MELTING}

Melting and fining occurs in refractory-lined furnaces at temperatures up to about $2800^{\circ} \mathrm{F}$. The temperature of the batch is raised as quickly as possible to the melting temperature where various dissolution, volatilization and redox reactions occur. Soda-lime glass must be raised to nearly $2730^{\circ} \mathrm{F}$ to eliminate entrained air (seeds) (Berg 1982). At this temperature, the gaseous seeds resulting from the melting process $\left(\mathrm{SO}_{X}, \mathrm{NO}_{X}\right.$, fluorine, etc.) rise through the not glass.

The majority of glass is melted in natural-gas-fired regenerative furnaces or recuperative unit melters. Electric melters are used in some segments of the glass industry. Table 3.3 lists the types of furnaces commonly used by each segment of the industry, the capacity range and the typical capacity. 
TABLE 3.3. Typical Furnace Types and Capacities

\begin{tabular}{|c|c|c|c|}
\hline Segment & $\begin{array}{c}\text { Range } \\
\text { (tons/day) } \\
\end{array}$ & $\begin{array}{r}\text { Typical } \\
\text { (tons/day) } \\
\end{array}$ & Type \\
\hline $\mathrm{Flat}$ Glass & $300-1000$ & 500 & Side-port regenerative \\
\hline Container & $50-480$ & 180 & $\begin{array}{l}\text { Side-port regenerative } \\
\text { End-port regenerative } \\
\text { Electric }\end{array}$ \\
\hline Insulating Fibers & $50-150$ & 100 & $\begin{array}{l}\text { Recuperative unit meiters } \\
\text { Electric }\end{array}$ \\
\hline Textile Fibers & $20-100$ & 60 & $\begin{array}{l}\text { Recuperative Unit melters } \\
\text { Electric }\end{array}$ \\
\hline Pressed/Blown & $1-300$ & NA & $\begin{array}{l}\text { Side-port regenerative } \\
\text { End-port regenerative } \\
\text { Recuperative unit melters } \\
\text { Day tanks } \\
\text { Pot furnaces } \\
\text { Electric }\end{array}$ \\
\hline
\end{tabular}

Personal Communications: Henry F. Teichmann, Inc., Pittsburgh, Pennsylvania; Glass Incorporated International, Covina, California; Toledo Engineering Company, Inc., Toledo, Ohio. Literature: Berg 1982; Schorr 1975.

Regenerative furnaces are used in the flat glass and container glass industries because they provide higher capacities and produce high-quality glass. Insulating wool fibers are produced from unit melters and electric melters. In general, specialty glasses, such as vitreous silica, leaded glass, opal glass, electronic glass, sealing glass and glass for optical fibers are produced in a wide variety of day tanks and pot furnaces in relatively small quantities.

The major factor that determines the type of glass furnace and the design is economics within the constraints of glass chemistry, end product specifications, rated throughput, local regulations, and fuel availability.

The glass chemistry (see Table 3.2) dictates how corrosive the glass will be and the temperature to which it must be heated. In general, the low-alkali borosilicate glasses (i.e., those containing small quantities of sodium oxide) require higher temperatures to meit than soda-lime glasses. The melting 
temperatures required for high-alkali borosilicate glasses (e.g., insulations) are generally lower than those required for soda-lime glasses.

The product specifications weigh heavily on the the overall design of the melting and forming process as well as on the scale of operation. For example, in the flat glass industry, the quality of the glass is extremely critical to customer acceptance. Thus, much more residence time in the furnace is allowed for refining and conditioning the glass prior to drawing relative to other glass products. The seed content of float glass is far less than that of tableware although more energy is used in melting the tableware. This is due partly to the scale of the operations. The large float glass tank lends itself to better glass quality and higher energy efficiency than the small tank used for tableware.

Due to the generally small scale of operation, there is little opportunity for significant industry-wide energy conservation resulting from research on specialty glasses. Therefore, only the design, operation and energy use of regenerative furnaces, unit melters, and electric melters are addressed in this section.

\subsubsection{Regenerative Furnaces}

Regenerative furnaces are of two basic types: side-port and end-port furnaces which are distinguished by their firing and exhaust gas flow patterns.

In side-port furnaces (Figure 3.5), the exhaust ports and burners are located along opposing sides of the furnace. Firing and exhausting alternate between opposing sides at 20- to 30-minute intervals. End-port furnaces aiternately fire and exhaust from two ports located on the back wall of the furnace (Figure 3.6). In general, an end-port furnace is more fuel-efficient than an equally sized side-port furnace at the beginning of a campaign. However, the end-port firing pattern leads to higher rates of wear on furnace refractories relative to the side-port, such that fuel use near the end of a campaign may be equivalent or higher.

In general, end-port furnaces are smaller than side-port furnaces. Although some end-port designs are now operating at capacities as high as 350 to 400 tons/day (Tooley 1984). These higher capacities are achieved with the 


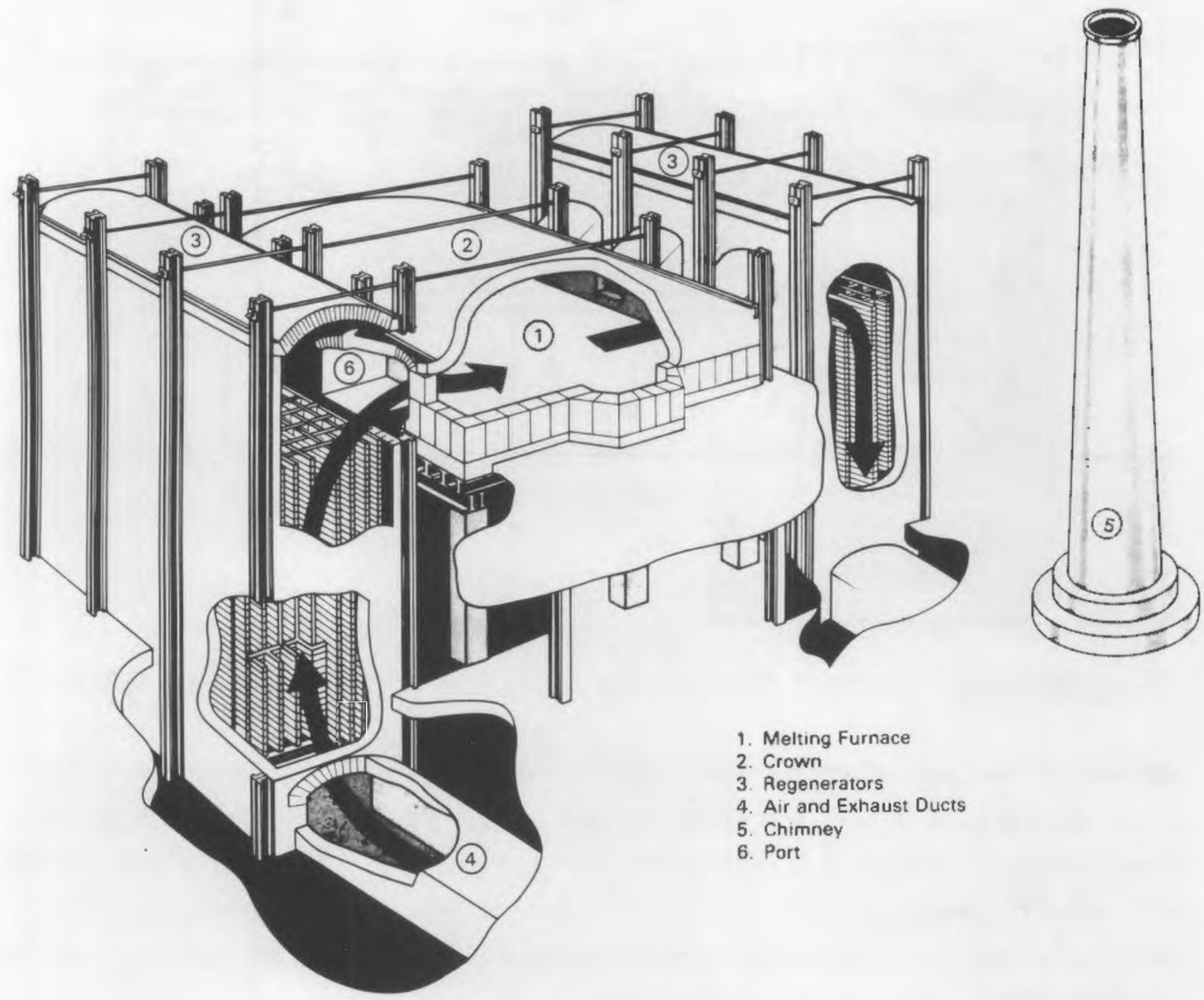

FIGURE 3.5. Side-Port Regenerative Furnace

use of electric boosting. Relative to end-port furnaces, side-port furnaces have the advantages of: 1) longer campaign life, and 2) the ability to produce high quality glass over a wide range of operating practices. Product quality and capacity considerations have generally limited the float glass process to side-port furnaces, whereas the container glass industry uses both end-port and side-port furnaces.

The specific energy consumption of a typical float glass furnace is on the order of 5.5 to 7.5 million Btu per ton melted. The specific energy consumption of a typical container furnace is about 5.0 to 6.0 million Btu per ton. 


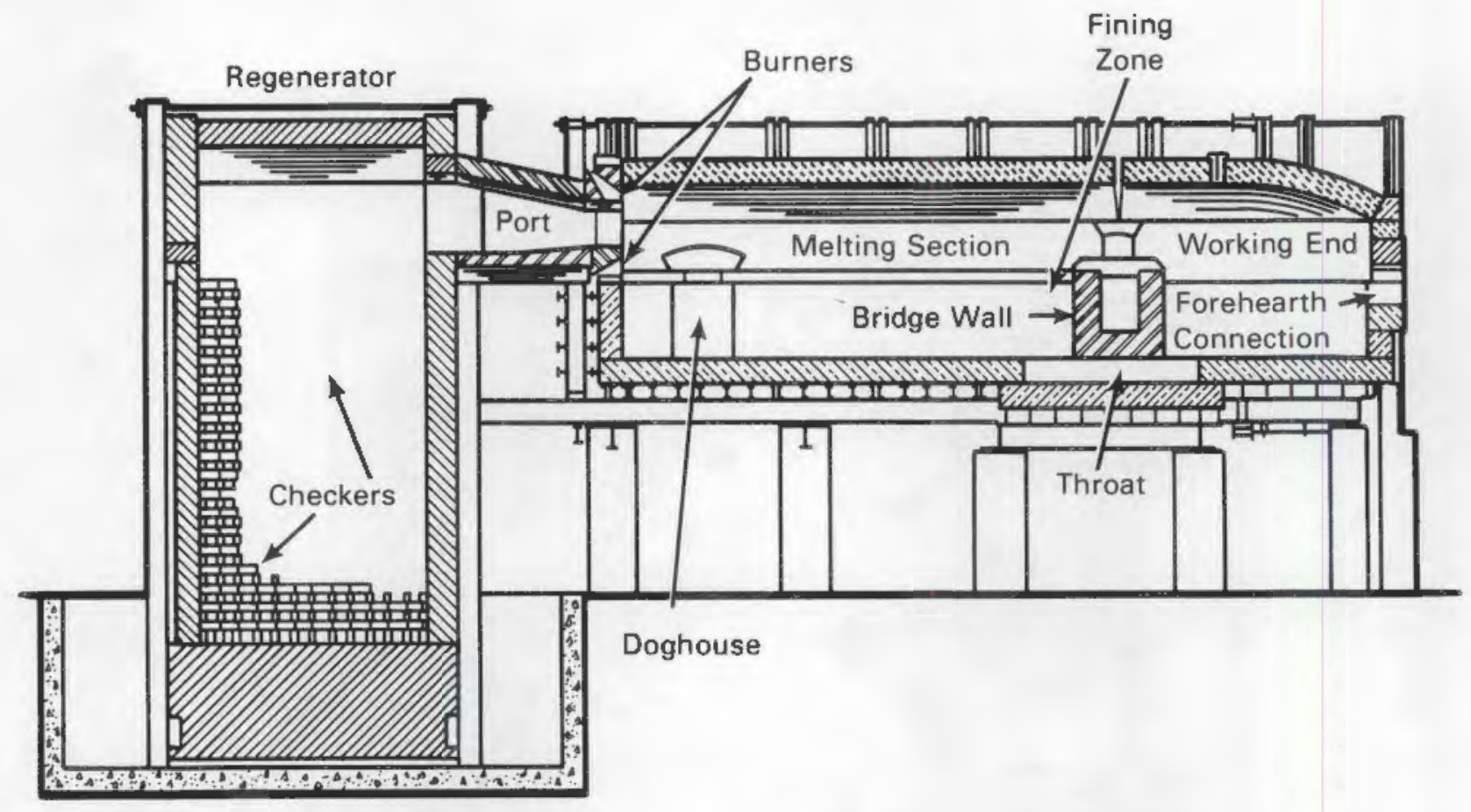

FIGURE 3.6. End-Port Regenerative Furnace (Adapted from Tooley 1984)

Well-built and well-operated container furnaces have specific energy consumptions as low as 4.0 to 4.5 million Btu per ton. The best efficiency that has been quoted to date is 3.2 million Btu per ton for a fossil-fired glass furnace with electric boost in South Africa.(a) Typical soda-lime compositions have been calculated to theoretically require about 2.0 to $2.2 \times 10^{6} \mathrm{Btu} / \mathrm{ton}$ (Utsler and Ross 1980).

The choice of refractories in regenerative glass melters plays an important role in furnace life and glass quality. The refractories in contact with the glass and those on top courses of the regenerators are the first to wear out. A typical soda-lime container or float glass furnace has a life of 6 to 8 years. During this time the furnace is kept at temperature and is full of molten glass. As the furnace ages its energy use increases. Over the campaign life of a typical regenerative furnace, the specific fuel use may increase as

(a) Personal communication with Al Garrone, Henry F. Teichmann, Inc., Pittsburgh, Pennsylvania. 
much as 15\%. This is due to a number of factors such as erosion and corrosion of sidewalls, air infiltration, and regenerator wear.

Most furnaces today are reasonably well insulated. However, glass furnace insulation is not a simple matter. If too much insulation is put on high-wear areas such as the sidewalls, the refractory will get too hot and wear will rapidly increase. This not only reduces furnace 1 ife, it introduces stones and seeds in the product. The resulting poor-quality product must then be discarded or recycled as cullet. In any case, the energy spent on the discarded product is wasted. In this situation the energy efficiency of the process actually decreases by adding insulation to the furnace. Anticipated refractory life and high-temperature performance with a particular glass composition are key factors influencing the degree of furnace insulation.

\subsubsection{Unit Melters}

Unit melters are unregenerated glass melting furnaces that do not reverse direction of firing (see Figure 3.7 ). These melters range in size from about

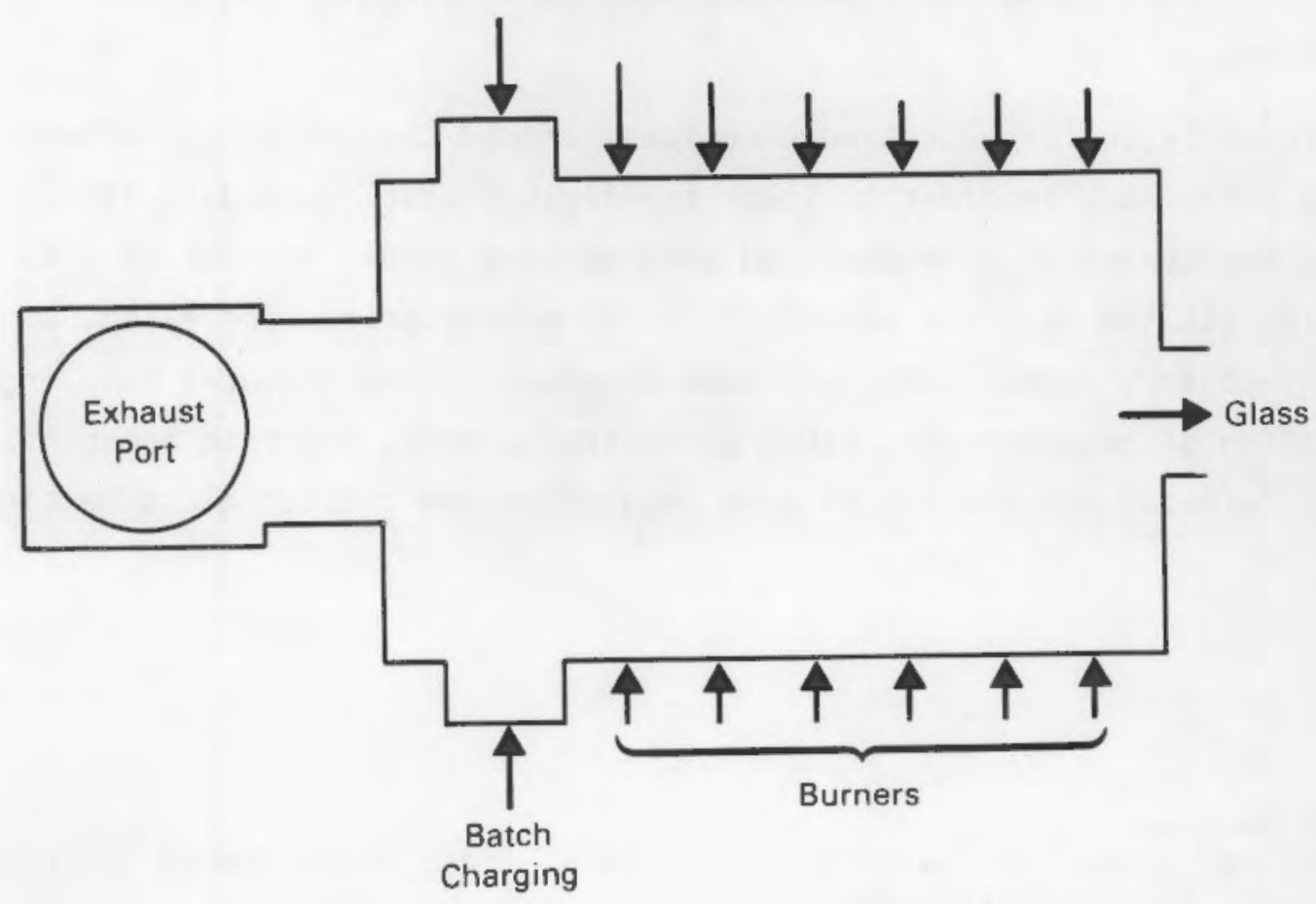

FIGURE 3.7. Unit Melter 
50 to 150 tons/day. (a) In these furnaces, fuel (usually natural gas) is combusted in two banks of opposed burners located along the sides of the furnace. The burners fire continuously, unlike those in regenerative furnaces, providing more stable temperature conditions. Burners are divided into zones, with the zones controlled to maintain a longitudinal temperature gradient along the melter to enhance convective mixing in the melt. In general, for fiberglass the temperature is around $2498^{\circ} \mathrm{F}$ in the melting zone, $2768^{\circ} \mathrm{F}$ in the fining zone, $2228^{\circ} \mathrm{F}$ in the doghouse entrance, and $2147^{\circ} \mathrm{F}$ in the stack (Arrandale 1984). The hot combustion gases are drawn over the batch surface and exit out a port located at the charging end of the furnace. The exhausts may be vented to the atmosphere through pollution control equipment, or they may be routed through a metallic recuperator to preheat combustion air.

Unit melters are usually chosen over regenerative furnaces when initial capital is a problem and/or steady temperature conditions are required and/or the daily tonnage is too small to make practical or economic use of regenerators. In addition, the corrosive constituents in borosilicate glasses make it difficult to maintain checkers because of plugging and brick degradation.

Originally, unit melters were designed around the philosophy of sacrificing fuel efficiency in order to lower the capital cost (Arrandale 1984). The specific energy use of unrecuperated unit melters ranges from about 8 to 18 million Btu/ton of glass melted. $(b, c)$ As energy prices increased, a number of energy-conserving measures have been adopted. These measures have included installation of recuperators, batch agitating systems, electric boosting, all electric furnaces and the use of more insulation and greater glass melting depths.

(a) Personal communication with Albert Lewis, Glass Incorporated International, Covina, California.

(b) Personal communication with Thomas Stark, Manville Service Corporation, Denver, Colorado.

(c) Personal communication Associated Technical Consultants, Toledo, Ohio. 
Metallic recuperators have been retrofitted to unit melters to recover the heat from the melter exhaust to preheat combustion air. Reductions of 25 to $30 \%$ in the specific energy use of unit melters producing insulation fiberglass have been reported (Stark 1985).

There are currently two basic types of metallic recuperators available to the glass industry: a double-shell and a tubular design. The double-shell recuperator (Figure 3.8) consists of two concentric cylinders. The combustion exhaust gases are drawn through the inner cylinder and the combustion air passes through the annulus. The tubular design (Figure 3.9 ) consists of a group

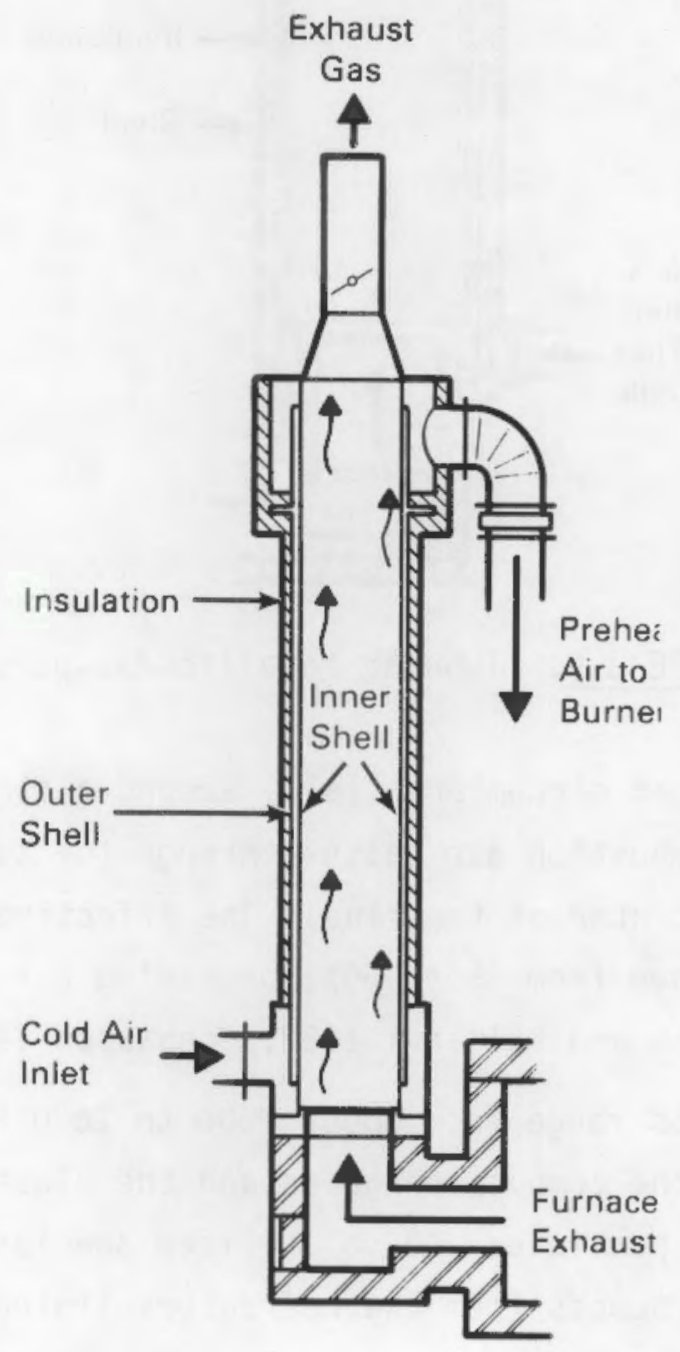

FIGURE 3.8. Double-Shell Metallic Recuperator 


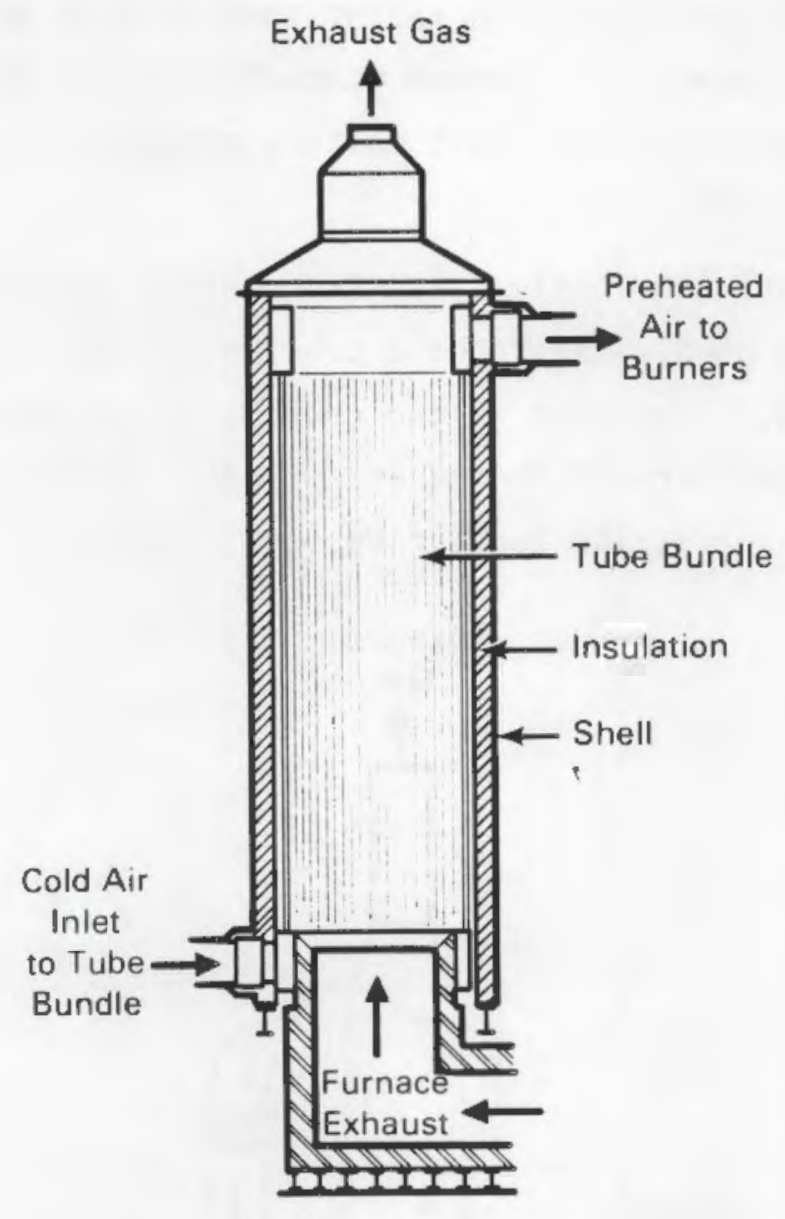

FIGURE 3.9. Tubular Metallic Recuperator

of circular tubes arranged circumferentially around a flue, parallel to the waste gas flow. The combustion air passes through the tubes and the exhaust gases pass through the center of the flue. The effectiveness of these recuperators is reported to range from 35 to $50 \%$, providing air preheat temperatures from 1000 to $1500^{\circ} \mathrm{F}$ (Webb and Kulkarni 1982, Seehausen 1984).

Unit melter exhausts range from about 2000 to $2600^{\circ} \mathrm{F}$. Because of the direct contact between the combustion gases and the glass batch, the furnace exhausts are laden with particles and volatilized species from the batch. In addition, degradation products from the refractory lining may also be carried over in the exhausts. The particles consist primarily of $\mathrm{Na}_{2} \mathrm{SO}_{4}, \mathrm{Na}_{2} \mathrm{O}, \mathrm{SiO}_{2}$, and $\mathrm{CaO}$. The gas-phase constituents include $\mathrm{NO}_{x}$ and $\mathrm{SO}_{x}$. The use of expensive 
alloys, such as stainless steels or Inconel, is required to withstand this high-temperature, corrosive environment.

\subsubsection{Electric Melters}

Molten glass is a relatively good conductor of electricity. The electric melting of glass is based on Joule's Principle where the molten glass is used as the resistive element of the electrical circuit. Electric melters appear simple but in fact require significant engineering expertise. The placenent and composition of the electrodes and the voltage and current characteristics of the power supply transformers require an understanding of the electrical properties of the molten glass as a function of temperature. These data are usually not readily available, so the design of an electric melter is based on empirical formulas developed on similar glasses (Steitz and Hibscher 1980).

The development and use of the electric melter have expanded slowly since its inception. Electric melters are upwards of $65 \%$ thermally efficient. Al1electric melters reportedly use 2.9 to 3.1 million Btu per ton of glass. (a)

One of the key advantages of an electric melter is that the batch is added to the top of the melter and melted at the bottom. The top of the batch is cool and forms an insulating cold cap over the molten glass. This characteristically nearly eliminates energy loss from the surface of the melt. There are no combustion gases and batch carry-over and the subsequent air pollution are reduced. Electric melters are reported to cost anywhere from about a third more to $50-75 \%$ less than comparable gas melters. Although they last only 2 to 3 years, the brick work is less, reducing the cost of rebuilds. (b) Even though the cost of electricity ranges between three to six times that of gas on an equivalent thermal basis, the high efficiency and nonpolluting aspects of the electric furnace make it attractive for insulation fiber glass and high-temperature borosilicate glass production (Hibscher 1982). In addition, electric melting is the best method for melting glasses containing highly volatile constituents (fluoride, phosphate, borosilicate,

\footnotetext{
(a) Personal communications with Albert Lewis, Glass Incorporated . International, Covina, California and Al Garrone, Henry F. Teichmann, Inc., Pittsburgh, Pennsylvania.

(b) Personal communication, Associated Technical Consultants, Toledo, Ohio.
} 
lead, and similar glasses) (Penberthy 1984). Glasses with high resistivities require more closely spaced electrodes and are difficult to melt electrically.

\subsection{FORMING OPERATIONS}

Prior to forming, the glass must be transferred from the furnace to the forming equipment, typically through a forehearth. Energy is consumed in the forehearth for selective cooling and/or heating to achieve thermal uniformity. Refiners and forehearths typically use between 0.1 and $0.2 \mathrm{milli}$ ion Btu/ton with the least efficient equipment using as much as 0.5 million Btu/ton(a). Forming operations vary widely depending on the product and consequently the energy consumption of these operations varies over a wide range. The float forming process consumes about 5\% of total plant energy (Miller 1982) at the low end of the range, while a high of $50 \%$ (b) of total plant energy is used in some fiberforming processes. These percentages include the energy used to condition the glass in the forehearth as well as the forming energy.

This section describes the forming processes presently used in each glass industry segment and their corresponding energy use.

\subsubsection{Container Forming}

To form a container, molten glass must first be transferred from the furnace to the forming machine. There are two methods used to transfer molten glass to the forming equipment. Glass can be sucked up into a forming mold brought in contact with the glass surface or molten glass can be forced through openings in the forehearth. The latter operation (gob feeding) is predominant in the glass container industry today. In gob feeding, a revolving tube and reciprocating plunger control the weight and shape of molten glass gobs flowing through an orifice and mechanical shears cut the glass to form the gobs. The temperature of the gobs can range from $1800^{\circ} \mathrm{F}$ to $2250^{\circ} \mathrm{F}$ (Tooley 1984).

Temperature control is critical to the transfer operation. If the glass cools too much, it could become too viscous to transfer or form properly. Additional heat (gas or electric) may be added in the forehearth to control the

(a) Personal communication, Associated Technical Consultants, Toledo, Ohio. (b) Personal communication, Manville Service Corporation, Cleborne, Texas. 
rate of cooling of the glass and to compensate for heat losses at the outer edges of the flow channels. It is estimated that the conduction and radiation losses through the forehearth superstructure are on the order of 0.1 to 0.2 million Btu/hr per foot of forehearth (Clark-Monks and Reynolds 1980). The use of cooling air in conjunction with heating provides the ability to achieve temperature uniformity at increased pull rates. However, since in the traditional forehearth, the cooling and heating operations are both directed at the glass surface from a common plenum above the glass, the cooling air has the opportunity to mix with the combustion gases thus diluting the effect of either operation. Additional heat must be input to maintain the temperature of the glass along the channel walls. While some forehearths operate without forced cooling, this practice generally requires longer forehearths and thus more energy to mitigate the sidewall losses.

Improvements in forehearth design have been made primarily with the aims of reducing undesirable temperature gradients in the glass and of improving temperature control. These developments have included radiant electric heating, immersed electrode boosting, all-electric heating ( $\mathrm{Clark}$, Monks and Reynolds 1980), and a new gas-fired design which divides the plenum into three sectors such that the combustion gases are routed along the side walls where most of the heating is needed. The cooling air is routed through passages above the plenum roof and below the channel floor which keep it completely separate from the combustion gases. Independent control of gas firing on each side and of the top and bottom cooling passages provides for greater temperature uniformity and control (Ceramic Industry February 1985).

The molds require a constant temperature to ensure consistent ware quality and optimum production levels. The mold temperature is controlled within a narrow range. Special cooling systems are used to control the rate at which the mold heat dissipates. Cooling systems are controlled to compensate for changes in ambient air temperatures, feed rate and temperature variations of the glass gobs.

The major container forming processes include the suction and blow, blow and blow, and press and blow methods. The first two methods are used to make 
narrow neck containers while the press and blow is best suited for wider mouth containers. The basic steps in each process are:

- Suction and blow: The bottom of a blank mold is dipped into the molten glass reservoir while suction is applied to draw up the glass. The intermediate glass shape (parison) formed in the first blank mold is transferred to a second blow mold for final blowing and shaping.

- Blow and blow: First, the gob is transferred to a blank mold and is settled with compressed air (settle blow). Then, it is preformed with compressed air (counter blow). The parison is then inverted and transferred into a second blow mold where it is blown into its final shape with compressed air (final blow).

- Press and blow: This method differs from blow and blow by using a plunger to form the initial parison in a blank mold. The parison is then inverted and transferred to a blow mold for final shaping by blowing.

The individual section (IS) machine is the most widely used forming machine and is considered the standard of the industry today. IS machines are capable of handling a variety of different types and sizes of molds. The IS machine can be used to form glass by both the blow/blow and press/blow techniques and can be easily converted from one forming method to the other. The IS machine differs from the other types of forming machines in its forming cycle, which leads to its greater flexibility and productivity. Differences between the IS and other types are as follows:

1. Each "individual section" of the machine contains its own set of blank and blow molds, being independent of the other sections

2. The IS molds do not rotate but rather the formation of the parison and final product are each done at one location

3. The IS gob is delivered to the mold instead of visa versa as in the other methods (Haines 1977).

The IS machine is capable of working in single, double, triple and recently quad gob applications, depending on the size/shape of the ware being formed. 
The trend has been toward larger capacity machines over the last decade with the triple gob growing to represent $16 \%$ and double gob $79 \%$ of total IS machine population in 1981, while the single gob has fallen to a low of $5 \%$. Most recently (1982/83) the quad gob IS machine has been introduced by manufacturers such as Owens-Illinois and Maul Technology, USA (Glass Industry, February, Apri1, 1984; May, 1985). The double, triple and quad gobbing machines have greatly increased the speeds of bottle making. Double gobbing operations are generally used for containers weighing up to about 20 ounces. Output can be increased up to $75 \%$ for small bottles and up to $60 \%$ for larger ware over the single gobbing techniques. Triple gobbing can be used for bottle weights of up to 10 ounces with output increasing 125 to $250 \%$ over single gobbing methods. (Tooley 1984). The average production speed per forming machine today is 120 bottles/minute (Edgington 1984).

The forming operations in the glass container industry use electrical energy almost exclusively. Electricity is used primarily to generate compressed air for glass blowing. Overall, the forming operations may account for about half of the total plant electricity load. As a percentage of total plant energy, the container forming processes in an average plant utilize about $12 \%$ of total plant energy.

The energy consumed by the forming equipment itself is not the most important consideration from a conservation standpoint. Instead, there are two important forming parameters which have a direct bearing on the energy productivity of a container plant. These are: 1) the weight of the container, and 2) the efficiency at which it is produced (Osborne 1982).

In general, the lighter the container, the less energy required to produce that unit. Table 3.4 provides a sample of bottle types, their weights, and the energy used to produce them. Although the specific energy use is around $3.3 \times 10^{3} \mathrm{Btu} / 1 \mathrm{~b}$ for each of the containers listed, the energy use per container varies by a factor of three. 
TABLE 3.4 Energy Requirements for a Sample of Glass Containers (Adapted from Osborne 1982)

\begin{tabular}{|c|c|c|}
\hline Bottle Type & Weight (1b) & Production energy $(B t u)(a)$ \\
\hline $1-1$ iter mineral & 1.20 & 4000 \\
\hline 0.75-1iter liquor & 1.14 & 3795 \\
\hline $0.7-1$ iter wine & 1.09 & 3615 \\
\hline 10-0z wide mouth beer & 0.41 & 1360 \\
\hline 1-1b jam & 0.38 & 1245 \\
\hline
\end{tabular}

(a) Based on an $85 \%$ production efficiency.

The higher the production efficiency, (a) the lower the energy consumed to produce a unit of good product. Glass which ends up as cullet represents an energy loss. Figure 3.10 shows the effect of production efficiency on specific energy use as a function of container weight. The range of containers produced in the U.S. weigh from about 0.13 to $2.21 \mathrm{~b}$ (McLellan and Shand 1984). Although Edgington (1984) reports that state-of-the-art IS forming equipment has an average production efficiency of about $86 \%$, industry sources indicate that many container plants achieve efficiencies of greater than $90 \%$ (b)

\subsubsection{Flat Glass}

The molten $\mathrm{glass}$ flows onto a molten tin bath at about $1950^{\circ} \mathrm{F}$. The bath is approximately 160 feet long and 12 feet wide (Yunker 1984). On this bath, the glass smooths out to the perfect flatness of the tin surface, developing a uniform glass thickness and a high quality glass surface. The float chamber has several different temperature zones, all with nitrogen atmospheres to prevent tin oxidation. The temperature zones provide for heating, fire-polishing, and cooling of the glass ribbon. The glass emerges from the float chamber at about $1125^{\circ} \mathrm{F}$ and it enters a lehr for final annealing and cooling.

(a) The ratio of net good product to gross production volume, commonly called pack-to-melt ratio.

(b) Personal communications with Mr. Robert Cunningham and with Associated Technical Consultants. 


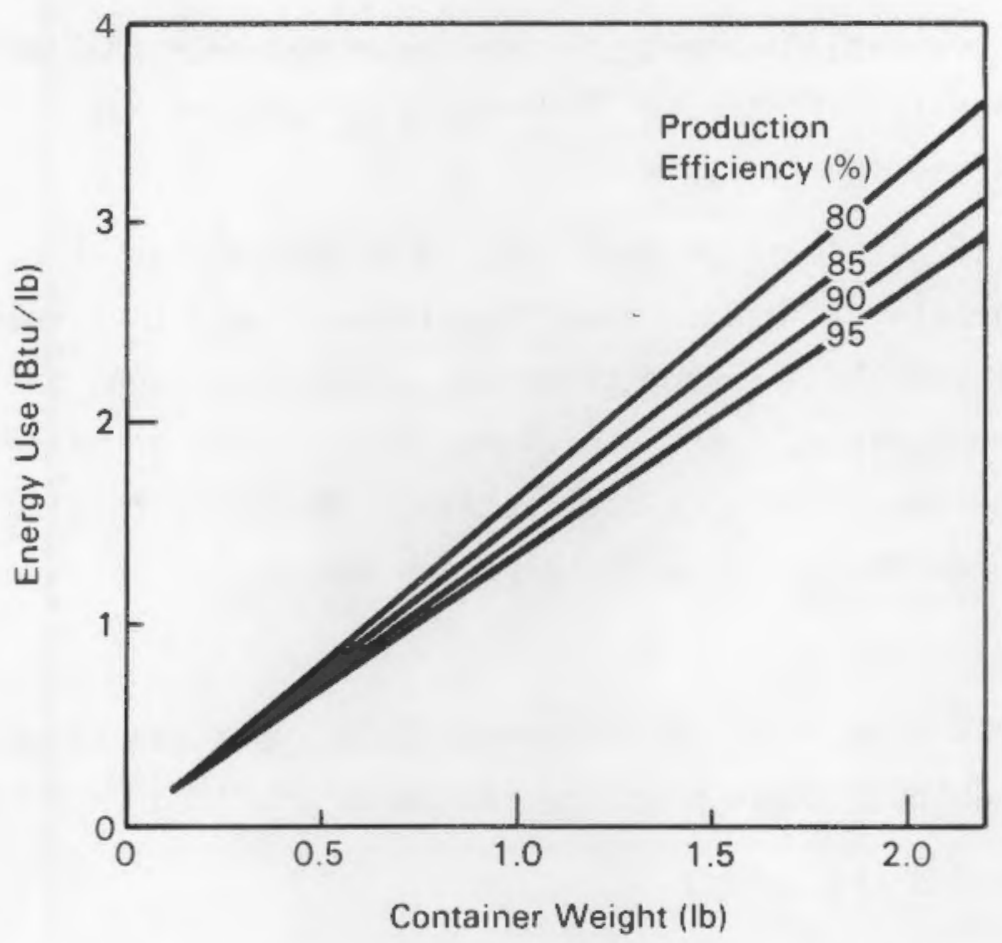

FIGURE 3.10. Energy Use as a Function of Container Weight at Various Production Efficiencies

(Modified from Osborne 1982)

Float glass technology was first introduced by Pilkington Brothers in the 1950s. In 1974, another float-forming process was developed by PPG, Incorporated. The two processes differ primarily in their molten glass delivery systems. In the Pilkington process, the glass flows from the furnace, under a tweel, over a spout and onto the tin bath. The PPG delivery system allows the glass to flow directly onto the bath over a wide threshold and through a set of refractory guides (Edge 1984).

In both processes, temperature gradients develop in the glass at the point of delivery to the tin bath due to heat losses through the sides and bottom of the delivery canal. The delivery system used in the PPG process minimizes these losses thus reducing the bath area required for homogenization of the glass ribbon (Perry 1984). The PPG process reportedly uses less energy than 
the PB process, however, (a) energy figures have not been made available by the industry. PPG and its affiliated, licensed subsidiaries are using the PPG system. All others use the PB system.

Since the tin bath must be kept under a nitrogen blanket to prevent oxidation, electric heating is used. Power requirements are inversely related to the thickness of the glass ribbon produced. Overall though, the float process consumes only about one half the energy required in the grinding and polishing operations of the now outdated plate process. The float forming process for flat glass consumes about $5.0 \%$ of total plant energy.

\subsubsection{Fiberglass}

Fiberglass is made from six different glass types and is manufactured into a variety of products. These products can be categorized into four groups:

1 wools, unbonded and bonded

2. mats, staple fiber, and cut strands

3. textile strands and sliver

4. molded products, pipe insulation, ceiling tile and other specialties (McLellan and Shand 1984).

Fibers may be formed directly from the melting furnace or an indirect process can be used in which glass marbles are formed as an intermediate product and remelted prior to fiber forming. Another indirect approach (for superfine wool) involves using small rods versus marbles for later remelting and fiber forming. The indirect methods, offer operation flexibility and the intermediate form is more economical to ship than the final product.

The forming of fiberglass is currently done by four basic processes: 1) rotary fiberizing, 2) steam or air blowing, 3) mechanical traction or drawing, and 4) flame blowing. The four basic operations are summarized as follows (Tooley 1984, McLe1lan and Shand 1984, Schorr et a1. 1975):

(a) Personal communication with Kears Pollack, PPG Industries, Inc., Pittsburgh, Pennsylvania. 
1. Rotary Fiberization

A stream of molten glass is poured into a high-temperature alloy spinner rotating at 2000 to $3000 \mathrm{rpm}$. Glass fibers are thrown from a band of holes around the periphery of the spinner. The fibers, 3 to 6 microns in diameter, are attenuated by a downward blast of hot air or gas.

2. Steam or Air Blowing

Streams of molten glass flow from the forehearth or from a marble remelt pot through platinum alloy bushings. Tractive forces from jets of steam or air attenuate the glass into fibers. Either long uniform fibers or shorter, finer fibers together with particles can be produced by regulating the jet pressure or glass temperature.

3. Mechanical Drawing of Continuous Fibers Continuous filaments (textile fibers) are formed by direct or marble remelt operations where molten glass (E glass) flows through a multitude of small orifices in a platinum alloy bushing.

4. Flame Blowing

Primary filaments are first formed through multiholed platinum bushings in a forehearth or a marble remelt pot. The primary filaments are then fed before a high-velocity gas burner where they are remelted and attenuated into very fine discontinuous filaments.

The fiberglass industry is divided into two groups: textile and wool. Due to the diversity of fiber forming processes coupled with the direct or marble/ rod remeit options, the energy used in forming operations as a percentage of total plant use can be expected to vary widely. The indirect methods use more energy than direct fiber forming, since remelting is required. of the fiber forming processes, flame blowing uses the most energy and mechanical drawing uses the least. The variance in energy consumption for forming operations ranges from 19 to $50 \%$. The high end of the range is represented by a remelt operation using flame blowing. The low end would be represented by continuous textile fibers drawn directly from the melter. 


\subsubsection{Other Pressed and Blown Glassware}

This segment of the glass industry is highly diverse. Products include hand-made and machine-made table, kitchen, art and novelty ware; lighting and electronic glassware; and scientific and industrial ware.

The highest value and greatest weight of shipments (shown earlier in Table 2.8) are in the table, kitchen and artware subdivision of this industry segment. Within this subdivision, the majority of ware (> 85\%) is machinemade. The forming techniques of pressing, press and blow, and blow and blow are used. The individual section (IS) forming machine is used for the press and blow and blow and blow processing in making certain types of table and kitchenware. The IS machine and its operation are described in the previous section on container manufacture.

Simply-designed glassware (such as bowls, lids, and plates) is generally made using a mold, a plunger and a ring which forms the finish area. Pressed ware molds are generally made of cast iron, although in special cases various types of staintess steel or even more exotic materials are used. Machine pressing of glassware is usually done on a round, single-table machine in a onestage process in which one plunger is used on several molds.

Tables may be either air or motor driven. Pressing mechanisms may operate via simple air cylinders or massive mechanical toggle arrangements. Generally, the greater the weight of the article being produced, the greater the mechanical complexity.

Production speeds for pressed ware can range from 10 to 60 pieces per minute (Tooley 1984). This speed is generally a function of the time required for the glass to cool and set up in the press. Once formed, pressed articles are removed from the mold by air jets or vacuum lift, by automatic tongs synchronized with the pressing machine, by turning the mold over or at an angle, or by hand.

The press-forming process using hot iron molds requires carefully controlled mold temperatures. Molds are usually cooled by fans and/or compressed air while plungers are cooled by internally circulated water. The mold temperature 
is critical to prevent overheating and potential sticking of the ware to the mold. The mold can be sprayed with water or lubricants and dopes to prevent sticking (Tooley 1984).

Paste molds are commonly used for medium- and high-grade tumbler production. The parison is formed by a plunger in a cast iron mold. Then as this mold drops away, a two-section paste mold swings around the parison. This water-cooled mold is rotated during blowing to provide a smooth, high-luster finish.

Since this segment is so diverse in its product mix, a wide range in energy requirements for the forming processes can be expected. Hand-made ware forming processes consume an average of $11 \%$ of total plant energy. Machinemade ware forming processes consume an average of $16.5 \%$ of total plant energy (Schorr et a1. 1975; Miller 1982).

The lighting and electronic ware subdivision (lamp envelopes, television tubes and tubing) uses blowing, pressing, press and blow, casting and drawing techniques.

The incandescent lamp glass envelope is formed on a ribbon machine. The machine is supplied by a continuous stream of molten glass from the forehearth. The glass stream passes between two water cooled rollers which flatten the stream into a ribbon which has heavier sections at intervals. The notched ribbon is transported on a moving chain of steel plates, with each plate having an orifice to match one of the heavier ribbon areas. As the glass ribbon sags through these orifices to form small bubbles, a second chain carrying blowing tips puffs air into and expands the bubbles. The expanded bubbles are then enclosed in a mold where final blowing occurs. The molds are opened, the blown lamp envelopes are cracked away from the ribbon and conveyed to the annealing process (Mclellan and Shand 1984; Tooley 1984; Schorr et al 1975).

Television tubes are formed in two parts. The buik (or funnel) is formed by the casting process. In this process, molten glass is cut into gobs and dropped into molds. The mold is spun rapidly to spread the glass by centrifugal force uniformly over the inside surface of the mold. The face plate is pressed. 
There are many other more specialized glasses and components for use in the electronics industry. Glass components for electronic applications are manufactured in pressed, blown and drawn shapes. Examples of these electronic components include: Enclosure assemblies, resistors, capacitors.

Glass tubing, such as that used in fluorescent lamps, is formed by one of three drawing processes, the Danner, Vello or Updraw methods. In the Danner process, a regulated amount of glass falls onto the surface of a rotating, horizontal mandrel. The glass is pulled over and away from the mandrel as air is blown continuously through its center. Tubing dimensions are controlled by the drawing speed and quantity of air blown through the mandrel center.

In the Vello process, molten glass passes downward through the annular space between a vertical mandrel and a refractory ring set in the bottom of a special forehearth section of the melting tank. The drawing and cutting from the Vello machine is similar to the Danner process.

Large-diameter tubing and glass pipe are made using the Updraw process. Air is blown up through a cone to control dimensions and cooling. In addition to tubing, rod can be drawn from any of the three tube-drawing processes described. Air pressure is reduced or turned off, allowing the glass to collapse and form rod instead of tubing (McLellan and Shand 1984; Haines 1977).

The forming operations used to manufacture lighting and electronic ware typically consume about a $14.5 \%$ of total plant energy. Most of this is electricity for compressed air production and machine drive.

\subsection{POST-FORMING OPERATIONS}

After forming, a variety of strengthening and surface finishing processes may be used.

The percentage of process energy use attributable to post-forming operations varies over a wide range ( 8 to $20 \%$ ). Post-forming operations in flat glass are at the low end of this range while post-forming machine ware in the pressed and blown segment is at the high end (Schorr et al. 1975; Miller 1982). 
Energy used for process heat in post-forming operations varies from negligible to about $4 \%$ of the total fossil energy used by the glass industry (about 1013 Btu in 1981). Operations using significant amounts of process heat include:

1. ware annealing and tempering (container and other pressed and blown glass)

2. drying/curing/fume incinerating (fiber glass)

3. tempering and bending/tempering (flat glass)

4. laminating (flat glass).

\subsubsection{Annealing}

Annealing reduces stresses created during the forming process such that subsequent cooling or product handling will not cause article breakage. Annealing is accomplished by first raising (or maintaining) the formed glass to its annealing temperature, maintaining this temperature in order to relieve stress and to stabilize the glass, then cooling the glass to an equilibrium temperature at a rate such that stresses do not reoccur (Mclellan and Shand 1984). Annealing is performed in all glass processes with the exception of the direct fiber processes.

The basic elements of the annealing process, are (Fuller 1975):

1. The glass article is uniformly heated to a temperature just above its annealing point (1000 to $1050^{\circ} \mathrm{F}$ for 1 ime-soda glass).

2. The glass article passes through the annealing zone at a rate which allows the article to cool slowly from the annealing point to the strain point. This slow cooling prevents new temperature gradients from developing between inside and outside surfaces of the thickest glass sections of the ware.

3. Temperature uniformity is maintained across the width of the lehr to ensure consistent annealing of all ware. 
4. The temperature at the end of the annealing zone is closely maintained at less than the strain point (about $900^{\circ} \mathrm{F}$ for soda-lime glass).

Two broad types of annealing lehrs include:

1. Annealing lehrs for glass coming directly from a forming machine. This applies to ware of the container, pressed and blown and flat glass industries.

2. Decorating lehrs for containers and various pressed and blown ware that have been decorated after forming. These lehrs reheat the ware from ambient temperatures to required decoration firing temperatures and then subsequently reanneal the ware.

Lehr design has evolved through time in response to the demand for higher production speeds and energy conservation. Early lehrs were manually-operated, single-zone tunnel structures, fired with a single burner. More automated lehr designs which were longer and wider developed over time but these consumed increasingly more energy. State-of-the-art lehr designs have achieved energy savings with the following design features (Ulmer 1984):

1. modular or zonal design

2. strategically placed heat sources

3. efficient, balanced hot air recirculation with each individual zone

4. internal belt return

5. lightweight lehr belts

6. Low resistance drive components

7. ceramic fiber insulation

8. exhaust heat recuperation

9. variable speed fan and drive motors

10. spark-ignited, pilotless on/off firing.

The choice between a gas-fired or an electric lehr is one of preference and of economics. The advantages and disadvantages of each type are listed in Table 3.5. Currently, about $90 \%$ of all lehrs are gas fired and $10 \%$ are electric. 
TABLE 3.5. Advantages and Disadvantages of Gas and Electric Lehrs (a)

\begin{tabular}{|c|c|c|}
\hline & Advantages & Disadvantages \\
\hline GAS & $\begin{array}{l}\text { 1. Traditional use } \\
\text { More exact firing; } \\
\text { quicker temperature } \\
\text { response }\end{array}$ & $\begin{array}{l}\text { 1. 0ld equipment needs } \\
\text { flame protection system } \\
\text { to meet safety standards } \\
\text { 2. Higher initial capital cost } \\
\text { 3. Electric motors still required }\end{array}$ \\
\hline ELECTRIC & $\begin{array}{l}\text { 1. Cleaner } \\
\text { 2. Lower initial cost } \\
\text { by } 4 \text { to } 10 \% \\
\text { 3. No special safety } \\
\text { or training required }\end{array}$ & $\begin{array}{l}\text { 1. Penalty for peak power demand } \\
\text { 2. Requires large power } \\
\text { source and auxiliaries }\end{array}$ \\
\hline
\end{tabular}

(a) Personal communication with Melvin Roberts, E. W. Bowman, Inc., Uniontown, Pennsylvania.

Modern annealing lehrs reportedly have achieved a fuel cost savings of 85 to $95 \%$ over early designs (Ulmer 1984). In some cases, the new lehrs operate without the need for energy because the temperature of the ware entering the lehr is higher than the required annealing temperature. In this case, glass heat is dissipated under controlled conditions. With uninterrupted production, energy consumption for proper heat treatment approaches zero (van der Sijs 1973, E. W. Bowman Inc. 1985).

The percentages of total plant energy expended for post-forming operations (including annealing) varies widely between glass industry segments. Typical values for the container, pressed and blown and flat glass segments range from $8.0 \%$ to $22 \%$ as shown in Table 3.1. On a Btu basis, annealing consumes 500 to $1000 \mathrm{Btu} / \mathrm{ft}^{2}$ of flat glass (Haines 1977).

The following energy usages per ton of annealed product are reported for a cross section of Bowman lehrs operating throughout the world producing various types of ware (E. W. Bownan):

Natural gas lehrs: 44 to 188 cubic feet/ton of ware

Electric lehrs: 7.9 to $11.8 \mathrm{kWh} /$ ton ware 
Two state-of-the-art lehrs, one gas (at Incon Packaging) and one electric (at Ball Corporation), are shown to use only 8.14 cubic feet gas/ton and 2.04 to $2.33 \mathrm{kWh} /$ ton, respectively (E. W. Bowman). These figures represent a compilation of data from the glass manufacturers currently using Bowman lehrs. (a)

\subsubsection{Fiber Drying and curing}

Some glass fibers are spray treated with aqueous phenolic binders which must be subsequently baked or cured. Curing temperatures for wool insulation range from 350 to $900^{\circ} \mathrm{F}$ depending on batt thickness. An average range would be 550 to $650^{\circ} \mathrm{F},(b, c)$ The curing produces phenolic fumes which must be incinerated. Textile fibers that are not sprayed with phenolic binders are dried in ovens at about $280^{\circ} \mathrm{F}$ for 9 to 24 hours (BCL 1977). These ovens are typically gas-fired with automatic control.

Fiberglass post-forming operations include the drying and curing processes, which are the most significant energy users in this category of operation. Typical values are $10 \%$ of total energy used for textile fibers and $12 \%$ for wool fibers (Milier 1982). Fiberglass wool curing consumes 470 to $588 \mathrm{Btu} / 1 \mathrm{~b}$ and phenolic incineration $588 \mathrm{Btu} / \mathrm{lb}$. (BCL 1977).

\subsubsection{Tempering and Bending/Tempering}

Tempering is used to strengthen glass sheets used primarily in the architectural and automotive industries and to strengthen soda lime oven ware. Annealed precut and shaped glass sheets, ranging from 2.8 to $19.0 \mathrm{~mm}$ in thickness, are the raw material for the tempering process. Tempering is accomplished by first heating glass in a furnace to about $620^{\circ} \mathrm{C}\left(1148^{\circ} \mathrm{F}\right)$ after which it is rapidly quenched by forced air at ambient temperatures. Quenching causes the glass surfaces to shrink relative to the internal glass regions which are still hot enough to flow and remain stress free. Continued cooling, establishes a uniform temperature throughout the piece. Stresses are distributed such that the surfaces are in compression and the interior regions are in

(a) Personal communication with Melvin Roberts, E. W. Bowman, Inc., Uniontown, Pennsylvania.

(b) Manville Service Corporation, Denver, Colorado.

(c) Glass Incorporated International, Covina, California. 
tension. Tempered flat glass is about five times stronger than untempered or annealed glass. Tempered soda lime oven ware is about three times stronger than the annealed borosilicate ware that it replaces.

There are several types of in-line tempering systems based on both product and mode of operation. An in-line arrangement refers to an all-in-one system of loading, heating/bending, quenching, cooling, and unloading sections. Product-type systems include those from flat glass (mainly architectural products) and from bent glass (automotive products). Operating modes include continuous, batch or a batch-loaded continuous systems for flat glass products and a batch system for bent glass.

Several modes of heat transfer act upon the glass as it passes through the furnace section of the system. Ranked in order of decreasing importance, they are:

1. radiation heat transfer between the glass and the hot surroundings such as the heating elements, rollers, walls, floors, etc.

2. conduction between the glass and conveyance mechanism (rollers, tongs etc.)

3. natural convection to the glass from the furnace atmosphere

4. radiation heat transfer from within the glass itself.

Glass heating for bending and tempering automotive products and for tempering architectural products requires precise temperature control. There is a narrow range of temperatures which will yield an acceptable tempered product. This range is referred to as the temperature window as shown in Figure 3.11 . Controlling variables are heat input and conveyance speed. Although optimum tempering operations require that glass products be heated to uniform temperatures and then quenched uniformly, in practice temperature nonuniformities and glass deformities occur as a result of features associated with the differing conveyance, heating and quenching mechanisms.

Conveyance mechanisms can be one of three basic types: tong-held, roller hearth, or gas or air float. These conveyance mechanisms adversely interfere with the radiation to the glass. The tongs of tong-held operations tend to 


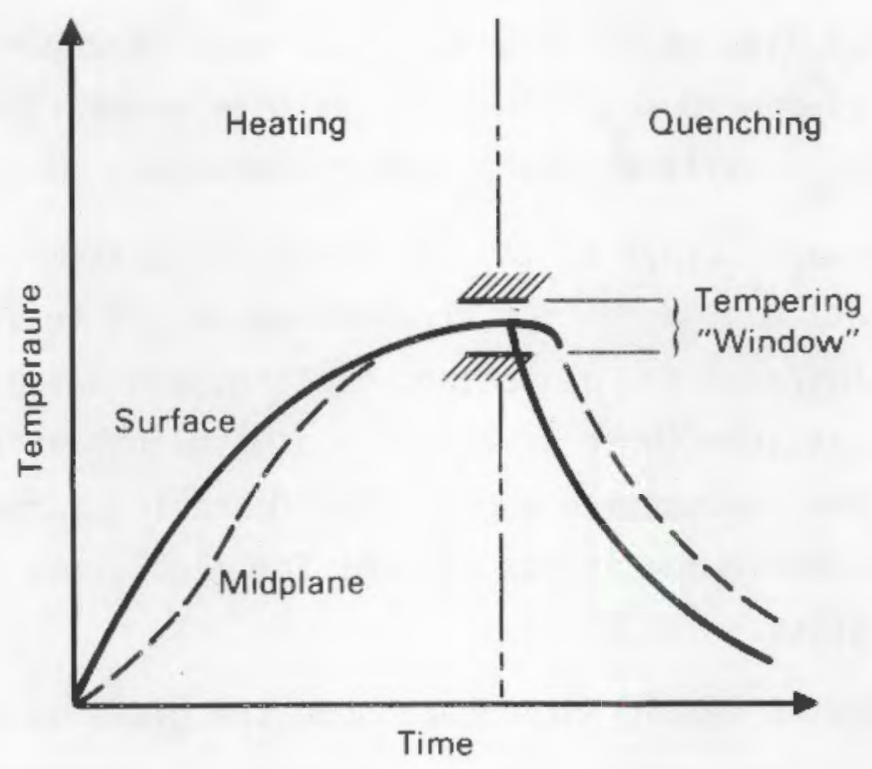

Source: McMaster, 1985

\section{FIGURE 3.11. Tempering Process}

shield glass edges as well as require their own heating energy. Rollers of the roller hearth type also tend to shield the glass bottom surfaces and cause contact heat transfer. Air/gas float schemes cause forced convection heat transfer to the bottom glass surfaces (McMaster 1984).

Radiant heating by electric resistance elements or gas burner systems ideally is supposed to heat the glass uniformly. However, even if the nonuniform heating effects of the conveyance mechanisms are eliminated, nonuniformities would still occur because of the "hot edge" effect. As radiant energy impinges on these areas, the temperature at the edge is elevated above that away from the edge (McMaster 1984).

Finally quenching deformities can be caused by nonuniform distribution of quenching-air over the glass surfaces. This problem increases as longer and wider glass pieces, such as architectural sheets, are conveyed through the quench system. 
A gas-fired, tong-held furnace uses $2.56 \times 10^{6} \mathrm{Btu} /$ ton, a gas-fired, gas hearth furnace uses $5.72 \times 10^{6} \mathrm{Btu} / \mathrm{ton}$, and an electric roller hearth uses $0.60 \times 10^{6} \mathrm{Btu} / \mathrm{ton}$ (McMaster 1985). Most bending/tempering furnaces have al ready been converted to electric heating. Only a few of the old technology, gas-hearth designs are still in use.(a)

The air quenching system uses electricity to power air blowers. Power requirements can vary depending on air pressure required for various pieces and glass thickness and can range from about $125 \mathrm{kWh}$ to about $625 \mathrm{kWh}$ for a vanecontrolled blower set up (Cuffle and Hammond 1985).

Overall, post-forming processes in the flat glass (float) industry consume an average of $7.0 \%$ of total plant energy with a range of 3.2 to $10.0 \%$ (Schorr et al. 1975; Miller 1982). These figures include bending, and tempering as well as annealing, laminating and washing/rinsing for this industry segment.

\subsubsection{Laminating}

Laminated glass is a made of a.plastic interlayer adhered between two or more layers of glass. Laminated glass finds its main use in the automotive industry as front windshields where impact strength is important. There are also architectural laminates.

The process for making laminated glass begins with raw, annealed glass sheets, cut to size and washed. Two glass pieces are required for manufacturing auto windshields. These glass sheets are usually bent in a bending furnace, but are not tempered.

The two pieces of bent glass are sandwiched with a plasticized polyvinyl butyral resin (PVB). This sandwiching process usually entraps air which is subsequently removed as the glass passes through rollers. Once deaired, the glass laminate is autoclaved to complete the bonding process. This is usually done in an autoclave at $150 \mathrm{psi}$. After autoclaving, the glass laminate is ready for any final finishing such as edge grinding or cleaning.

(a) Personal communication with Jim Blumer, Glasstech, Inc. Perrysburg, Ohio. 
Autoclaves for laminating used to use oil. State-of-the-art systems are electrical, forced-air systems which operate at about $400^{\circ} \mathrm{F}$. (a) The industry is phasing out the oil systems because of environmental considerations related to their use.

On a Btu basis, the autoclaving process used in laminating consumes about 0.31 to 0.4 million Btu/ton of product. The laminating process is one part of the post-forming operations associated primarily with the flat glass industry. Energy consumed for all post-forming operations in the flat glass (float) industry as a percentage of all energy consumed is about $7 \%$ (Miller 1982). This percentage includes laminating as well as annealing, tempering, bending and washing/rinsing.

(a) Personal communication with Tom Marquart, United McGill Corporation, Columbus, Ohio. 


\subsection{ENERGY-CONSERVING TECHNOLOGIES}

This chapter discusses energy saving technologies that can be applied to various steps in the glass-making processes. The discussion includes state-ofthe-art technologies which have not yet realized their full market potential, as well as technologies which are in the developmental or conceptual stage. Technologies may be categorized as evolutionary or revolutionary. Evolutionary technologies are developments which represent incremental improvements to existing technologies. A revolutionary technology represents a radical departure from existing technology.

Table 4.1 summarizes the estimated energy $\rightarrow$ savings potential of the technologies which appear to have the greatest conservation potential. The following methodology was used to estimate the energy-savings potential of each of the technologies:

1. determine percent savings of technology relative to current practice

2. identify technical market for technology

3. estimate annual savings as a percentage of technical market energy use.

Annual savings estimates are based on 1985 estimated energy-use and production data. The percent savings of the technologies reiative to current practice were obtained from the literature or were estimated based on its operating characteristics. For technologies which decrease or increase plant electrical use, utility transmission and conversion losses were taken into account. The assumptions made to define the technical markets are listed in Appendix $A$.

The most significant opportunities for application of energy conservation technologies are related to melting. In particular, oxygen enrichment, glass batch preheating, improved refractories, and computerized control systems have the greatest potential for incremental energy savings in the near term. In the long term, revolutionary technologies such as advanced furnace designs, a chemical approach to glass making, a thermo-chemical recuperator, and product lightweighting technology may yield significant energy savings. In addition, development of advanced materials capable of surviving in the glass furnace environment will provide the enabling technology for implementation of advanced thermal recuperators, cogeneration systems, and advanced sensors. 
TABLE 4.1. Estimated Energy-Savings Potential of Current and Advanced Technologies

Technology _ $\quad \begin{aligned} & \text { Industry Savings } \\ & \left(10^{12} \mathrm{Btu} / \mathrm{yr}\right)\end{aligned} \quad \begin{gathered}\text { Percent Improvement } \\ \text { (Relative to 1985) }\end{gathered}$

Incrementa l:

Oxygen Enrichment

$20-30$

$5-8$

Batch Preheating

20-30

$5-8$

Process Control

6-14

$1.5-4$

Improved Refractories

$5-10$

$1-2.5$

Improved Regenerators

$5-10$

$1-2.5$

Revolutionary:

Advanced Furnace Concepts

$50-75$

$13-19$

Advanced Recuperators

$30-70$

$8-18$

Chemical Processing

20-30

$5-8$

Cogeneration

13-18

3-5

Lightweighting

$9-18$

$2.5-4.5$

Advanced Sensors

$10-20$

2.5-5

Advanced Refractories

$10-20$

$2.5-5$

Advanced Refining Concepts

5-10

$1-2.5$

(a) Based on 1985 estimated production levels. Technologies which reduce power consumption were calculated in terms of primary fuel savings at the utility (i.e., $1 \mathrm{kWh}=11,500$ ).

(b) Based on 1985 estimated total energy use of 397 trillion Btu, which accounts for electrical conversion and transmission losses.

There are no significant opportunities beyond implementing state $\rightarrow$ f -theart technologies for saving the energy used directly in batch handling(a), forming, and post-forming operations. There are, however, opportunities for indirect energy savings through process changes in these operations. These changes impact energy used per unit of output through increased productivity and reduced product weight.

(a) There is a trend developing to handle batch ingredients pneumatically which will increase the electricity use per ton. 


\subsection{BATCH PREPARATION}

The glass industry has tried a wide variety of batch charging mechanisms and has developed the expertise to achieve proper batch charging. Although batch preparation and charging practices can have a major influence on melting energy use and product quality, the energy used in batch preparation is very small relative to overall plant energy use. Batch-preparation practices that result in reductions in melting energy use are discussed in the next section.

There are no opportunities to achieve large energy savings by improving the physical batch handling and conventional batch-charging practice. Standard housekeeping, load analysis, and motor matching could achieve small energy savings in pneumatic conveying. In some cases, particularly on older batch plants, the pneumatic batch-handling systems may be oversized. However, the glass industry tends to size all equipment for the worst case duty (Hartman 1985). For instance, a given machine may have a one-horsepower load when new but a two-horsepower load when old and worn. The general practice is to use a two-horsepower motor or larger on the machine. The reason for this is that there is usually no backup for the machine and it must operate continually for the entire campaign of the furnace. This is often as long as seven to eight years.

Oversizing results in a loss in installed efficiency because frictional losses are proportional to equipment size. If the load is small, then the losses represent a greater percentage of the useful output.

\subsection{MELTING}

Energy-conservation technologies that can be applied to melting include: process improvements, combustion efficiency improvements, and heat-transfer enhancements. Process improvements involve changes that reduce the theoretical amount of heat needed to melt the glass batch. Combustion efficiency and heattransfer enhancement technologies reduce the amount of heat that is wasted.

Table 4.2 lists the technologies that are discussed in this section. The list contains technologies that are becoming commonplace in some segments of the glass industry, foreign technologies which have not yet found wide 
TABLE 4.2. Energy-Conservation Technologies

Applicable to Melting

- Advanced Melting Concepts

- Chemical Boosting

- Sol-Gel Process

- Rhone-Poulenc Process

- Burner Design

- Oxygen Enrichment

- Electric Boosting and Melting

- Dual-Depth Melting

- Improved Refractories

- Batch Agitation

acceptance in the domestic glass industry, and advanced technologies which have not yet been commercialized. In general, the technologies which are being utilized to the greatest extent are those which increase output (e.g., electric boosting). Various glass industry personnel indicated that the key criteria the glass industry considers in the adoption of any technology are payback (generally 1 to 2 years) and equipment reliability. In addition, any furnace modifications that are made must be accomplished while the furnace is being rebuilt which occurs at about 6 - to 8 -year intervals. This tends to pace the rate of implementation of new technology.

\subsubsection{Advanced Melting Concepts}

Advanced melting concepts are under investigation which represent a radical departure from the conventional regenerative furnace which was first introduced in the last century. The approach taken in developing advanced melting concepts, in general, involves separating the operations which have traditionally all occurred in the conventional furnace melt tank: batch liquefaction, batch grain dissolution, melt homogenization and glass refining. The majority of this work is of a proprietary nature. Three concepts for which some information is available are described below. These include PPG, Industries, Inc. patents on glass batch liquefaction, the Gas Research Institute (GRI) advanced melter development program, and the Battelle Sonic Refining Technology. 
The PPG Industries, Inc, batch liquefaction concept would use the glass batch materials as the support upon which liquefaction of the batch takes place. A layer of batch is maintained as a lining in the liquefaction vessel and provides protection against thermal degradation or corrosion of the vessel structure. This permits the use of economic refractory materials. The liquefaction process is carried out at a lower temperature than conventional furnace operation. A proposed modification (Demerest 1985) would preheat batch materials using the exhaust gas from the liquefaction chamber in a rotary kiln arrangement.

Avco Research Laboratory, Inc., under contract to the Gas Research Institute, is developing the Advanced Glass Melter (AGM). In the AGM concept, glass forming materials are injected as fine particles into the high-temperature combustion air line and are transported in suspension to a high intensity gas burner. The materials are heated rapidly in suspension in the turbulent burner flow and approach the temperature of the combustion products as they pass through the burner. A converging nozzle at the burner exit accelerates the two-phase flow and directs it to a melt separation and refining chamber. The hot materials are separated inertially from the combustion gas and are deposited on a collecting surface where melting reactions, homogenization, and refining are completed. The thin glass layer flows from the collecting surface to a melt reservoir at the bottom of the chamber and from there through forehearth channels to the forming equipment. The combustion gases fiow through ports in the sidewalls of the melt reservoir and are ducted to downstream heat recovery equipment (Westra and Donaldson 1986).

Preliminary proof -of-concept tests have been conducted which demonstrated that cullet could be uniformly dispersed in the high-temperature air entering the gas-fired combustion chamber, melted in suspension during the short combustor residence time, and then inertially separated from the combustion products (Westra and Donaldson 1986).

The use of sound waves has been proposed by Battelle as a means of agitat ing the melt in the fining end of the furnace. The ultrasonic bath agitation method is expected to promote the removal of gas bubbles from the molten glass. It is estimated that this could increase the productivity of glass furnaces by 
5 to $10 \%$ by increasing the yield of defect-free glass. Another benefit is reduced stack emissions in proportion to the decrease in the amount of primary fuel burned. However, it is likely that a large energy source would be required to yield sonic waves of sufficient intensity to promote refining, since sound attenuation in glass is high. (a)

\section{Energy-Savings Potential}

It is estimated that the specific energy required in batch liquefaction to convert the liquid completely to glass would be on the order of 4.5 million Btu/ton of glass without heat recovery (Kunkle and Matesa 1983). The use of heat recovery would result in a lower specific energy use.

The performance goal established for the Avco/GRI concept is a specific melting energy use no higher than 3.2 million Btu/ton of glass (Westra and Donaldson 1986). This would represent about a $47 \%$ improvement over a typical glass container furnace, or a $20 \%$ improvement over best-available container furnace technology. If an advanced furnace concept can achieve these goals, we project an industry energy savings potential of 50-75 trillion Btu/year at 1985 production levels.

\section{Possible Barriers}

These concepts are still in the very early stages of development. Further proof-of -concept experiments will be needed to evaluate the AGM system performance using normal glass batch materials. Engineering studies are underway to determine the most desirable heat recovery system and other plant components to optimize the performance of a complete AGM production facility. A field demonstration of the system is scheduled to begin early in 1987 with completion anticipated by the end of 1988 .

\subsubsection{Chemical Boosting}

The addition of between 0.05 and 0.15 wt $\%$ of lithium to the glass formulation has been shown to reduce energy consumption, increase furnace pull capacity, and increase product quality and productivity (Carroll 1983). Lithium is

(a) Personal Communication, Associated Technical Consultants, Toledo, Ohio. 
usually added as lithium carbonate or in the form of a lithium-bearing ore such as spodumene. Lithium acts as a flux to reduce batch melting temperature (Foote Mineral Company).

\section{Energy-Saving Potential}

Glass Containers Corporation in conjunction with Lithium Corporation of America ran a 72 day test on a 220 - 230 ton per day flint glass furnace and found that the bridgewa? 1 temperature was reduced by 30 to $60^{\circ} \mathrm{F}$, and energy consumption was reduced an average of $6 \%$ from a median of about 5.3 million Btu per ton to a median of about 5.0 million Btu per ton. The pull rate increased by $1.7 \%$ during a 23 day period when the lithium concentration was between 0.12 and $0.14 \mathrm{wt} \%$.

Another test was run on an electrically boosted 280-ton-per-day furnace producing champagne green glass. The objective of this test was to determine the amount of electric boost that could be eliminated. It was found that an average of $300 \mathrm{kilowatts}$ could be conserved while maintaining the same pull rate as before the test.

Other results included improved chemical durability of the glass, increased surface brilliance, decreased batch carry-over, a decrease in mold swabbing and improved forehearth and feeder control.

We do not expect the use of lithium in glass formulations to increase significantly since lithium is relatively more costly than the fuel it saves. Any energy savings associated with lithium addition will likely be negligible on an industry-wide basis.

\section{Possible Barriers}

Lithium carbonate costs $\$ 1.54$ per pound and is only $40 \%$ lithium oxide (Chemical Marketing Reporter July 1985). Adding 0.15\% lithium oxide to 100 tons of glass would cost on the order of $\$ 460$. This ignores the added cost of storage, handing and mixing. The estimated energy savings associated with the lithium addition would amount to about 30 million Btu per 100 tons of glass. At a cost of $\$ 5.50$ per million Btu for natural gas, the energy cost savings of $\$ 165$ per 100 tons of glass does not cover the cost of the lithium. The electrical energy savings in the second example amount to about $\$ 360$ per 
day assuming an electricity cost of $\$ 0.05$ per kilowatt-hour. The economics could be improved if a low-cost lithium-bearing ore were available near a glass plant.

\subsubsection{Chemical Processing}

A chemical approach to glassmaking (sol-gel process) has been under development at more than 40 laboratories in the United States, Japan, France, Britain, and West Germany for a number of years. The sol-gel process forms glass shapes at room temperature, thus eliminating the energy-intensive melting operation. Until recently, however, sol-gel structures had a tendency to crack easily and to become granular. Recently, Or. Larry Hench at the University of Florida has developed an additive which reportedly mitigates these problems. (Gavagham Apri1 1985, Chemical Week March 1985).

A flowsheet of the sol-gel process developed at the University of Florida is shown in Figure 4.1. A solution consisting of tetramethoxysilane (TMS), an organic acid and water is prepared in a heated vessel (75 to $175^{\circ} \mathrm{F}$ ). During mixing, both hydrolysis and condensation polymerization reactions occur. First, the silicon and water form silicon hydroxide molecules, with each silicon molecule bound to four hydroxyl molecules. Then, during condensation, the

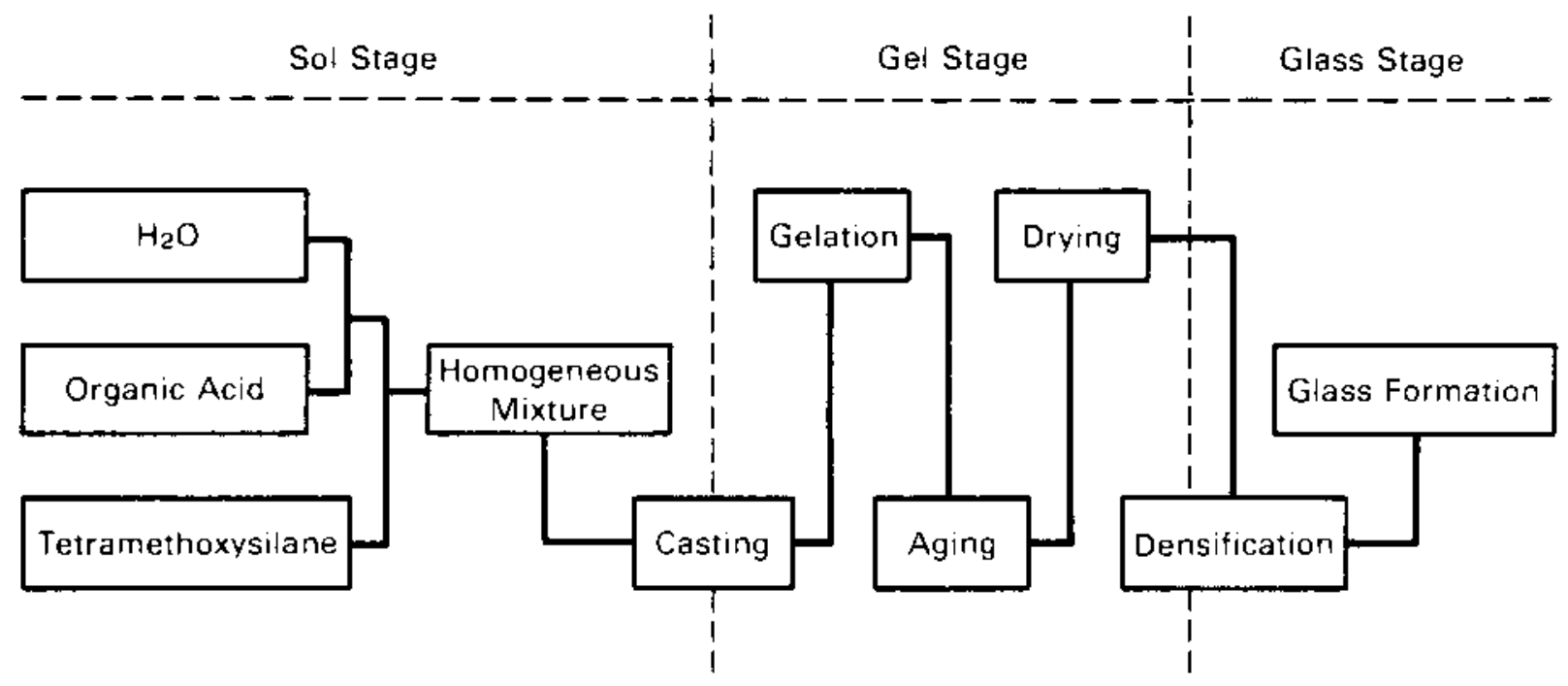

FIGURE 4.1. Sol-Gel Process (Hench 1985) 
silicon/hydroxide bonds are broken forming water and silicon oxide polymer solution. The solution is then poured into molds at room temperature. During the gelation step, the solution in the mold is held at about $160^{\circ} \mathrm{F}$ for 2 minutes to 6 hours. The solidified gel is aged in an oven at temperatures between about $70^{\circ} \mathrm{F}$ and $300^{\circ} \mathrm{F}$ from 1 to 15 hours. During the aging step, the gel densifies without drying. The residual liquid is removed by evaporation at temperatures ranging from $160^{\circ} \mathrm{F}$ to $400^{\circ} \mathrm{F}$ for 18 to 96 hours, depending on the size of the cast component. The densification stage involves holding the component at temperatures ranging from 300 to $2375^{\circ} \mathrm{F}$ for 1 to 3 days, depending on the desired density. (Hench, Wang and Park 1985).

\section{Energy-Savings Potential}

The sol-gel process may offer the opportunity for fuel savings through the use of lower temperatures during the preparation process and for electricity savings through the production of near-net-shape components. Near-term applications of the process will not likely replace conventional melting in the flat glass, container glass or fiber glass industries. Most likely, in the near term the process will be used to produce special optical glasses and new noncrystalline solids that are outside the range of normal glass formation processes.

The sol-gel process still faces many technical hurdles before it could be used for high-volume glass applications such as containers or flat glass. However, if a chemical approach to glass is perfected, the effect on the industry could be revolutionary. We estimate that a viable chemical approach might save 20 to 30 trillion Btu/year in the long-term if successfully developed for hightonnage glass production. Achieving these savings would require a $10 n g$-term research effort. While the risk would be high, the long-term return could be large with the possibility of short-term side benefits such as improved laser mirrors.

\section{Possible Barriers}

The sol-gel process in still in the developmental stage. The technical and economic issues associated with commercial-scale production need to be fully investigated. A net energy balance of the process, including raw 
material preparation should be prepared for comparison with conventional glassmaking processes. The net energy savings must be balanced against any additional costs for raw materials.

The raw materials used in the sol-gel process are toxic and must be handled in a controlled environment to ensure safety (McGinty 1985).

\subsubsection{Raw Material Purification (Rhone-Poulenc Process)}

A French firm, Rhone-Poulenc, has developed a new chemical process to produce purified raw materials for glass production. The company claims that the process offers major energy savings and higher productivity relative to conventional glass-making processes. In addition, the company says that the RhonePoulenc process uses raw materials that are 10 to 40 times less expensive than those used in the sol-gel process. Rhone-Poulenc is currently operating a 2-metric-ton/day pilot plant in central France which produces purified raw materials for lead glass production (Hunter 1985).

The Rhone-Poulenc process reacts potassium silicate $\left[6 \mathrm{SiO}_{2} \cdot 2 \mathrm{~K}_{2} 0.2 \mathrm{H}_{2} \mathrm{O}\right]$ with lead nitrate $\left[\mathrm{Pb}\left(\mathrm{NO}_{3}\right)_{2}\right]$ in an aqueous or organic solvent at room temperature. A precipitate of inorganic oxides that constitute lead crystal glass $\left[6 \mathrm{SiO}_{2} \cdot \mathrm{K}_{2} \mathrm{O} .2 \mathrm{PbO} \cdot 2 \mathrm{H}_{2} \mathrm{O}\right]$ is separated from the byproduct potassium nitrate through filtration. The precipitate, trademarked Crisver, is ready for vitrification in a conventional glass furnace (Hunter 1985).

\section{Energy-Savings Potential}

Because the Crisver is homogeneous and of high purity, it is believed that the time and temperature needed for vitrification can be reduced. RhonePoulenc claims that the high-purity material considerably reduces the lengthy fining stage required in glass manufacture. Crisver can be melted in an ordinary glass furnace at $1200^{\circ} \mathrm{C}\left(2192^{\circ} \mathrm{F}\right)$, which is below the $1400^{\circ} \mathrm{C}\left(2552^{\circ} \mathrm{F}\right)$ temperature required with conventional raw materials. (Chemical Week April 1985).

We estimate that this process may have the potential of saving 5 to $10 \%$ of the energy used by $10 \%$ of the pressed and blown glass industry. This amounts to approximately 0.2 to 0.3 trillion Btu/year at 1985 production levels, which is a negligible percentage of total glass industry energy use. 


\section{Possible Barriers}

The Rhone-Poulenc process is applicable only to highly-leaded glasses, which account for less than $10 \%$ of the production of the Pressed and Blown Glass segment. The economics of the process have yet to be demonstrated. Since the cost of materials represent the major production cost in glass manufacture, an increase in the raw materials costs would have to be offset by clear savings in energy costs to be attractive to the industry.

\subsubsection{Burner Systems}

The main areas where improved burner systems can save energy in glass furnaces are in flame shape control and elimination of cold inspirated or atomizing air. In many gas-fired glass furnaces, the "burner" consists of a steel pipe that conveys the gas at a specified angle through the bottom or sides of the regenerator port and into the furnace. In many cases there is an open area between the burner tube and the refractory wall where cool air is drawn into the furnace. This cool air affects the temperature distribution of the flame and reduces the efficiency of the furnace. Cold air inspiration can be eliminated by sealing the burner to the refractory. The cold inspirated air is then replaced with $2000+^{\circ} \mathrm{F}$ air from the regenerators. This preheated combustion air contributes 40 Btu per standard cubic foot to the melting process (Neff 1985).

0il-fired burners face a slightly different problem. Compressed air is used to atomize the $0 i 1$ and control the shape of the flame. Low-pressure oil atomizing burners typically use up to $15 \%$ of the stoichiometric combustion air at pressures between 16 and 32 psig. Combustion Tec Corporation of 0rlando, Florida and other manufacturers offer a medium pressure oil atomizing burner that uses a smaller volume of air at 40 psig to atomize the oil. The medium pressure burner typically uses two to $4 \%$ of the stoichiometric combustion air.

Atomizing air can be eliminated through the use of mechanical oil atomizing burners where the oil is atomized by passing it through small openings at high pressure (400 psig). Maintenance on this type of burner is quite high. Burners on regenerative furnaces are located in a hot and difficult-to-reach place between the regenerators and the melter. This type of burner is better suited to a unit melter where it would be easily accessible. 
Submerged burners were developed and tested as early as 1959. Submerged burners could potentially enhance heat transfer by firing directiy into the me1t. Since the flame and combustion products are contained within the molten glass, heat transfer is direct and heat losses to refractories are reduced. As the combustion gases flow upward through the glass they enhance mixing. To our knowledge, research in this area is not currently being actively pursued and no commercial facility uses this technique. Some contacts in the container segment indicated that this concept was not of interest because of potential product quality (color control) problems.

\section{Energy-Savings Potential}

There is an approximate ratio of 2.5 mole\% of cold air introduced into the furnace to $1 \%$ of additional fuel use (Neff 1985). It is difficult to predict the energy savings associated with sealing in a gas burner untess the volume of inspirated air is known. Furnaces vary widely in the amount of inspirated air due to differences in burner block openings, burner firing positions, furnace pressure, and fuel-firing rates. Experience indicates that the amount of inspirated air ranges from about $5 \%$ to $15 \%$ of the stoichiometric combustion air (Neff 1985).

In the case of converting a low-pressure air atomizing oil burner to a medium-pressure air atomizing burner, 11 to $13 \%$ of the cold air can be eliminated. This would result in about a $5 \%$ fuel savings in the melting process.

In most glass furnaces burners are not the problem, it is the infiltration of cold air. Burner technology is fairly well known to the glass industry and advanced burners have been installed in most of the places where they are economically justified. We estimate that further application of improved burners in the near-term could save about 3 to $5 \%$ of the energy in roughly $10 \%$ of all glass furnaces. This amounts to about 0.5 to 0.9 trillion Btu/year at 1985 production levels.

\section{Possible Barriers}

The main barrier with the use of the medium-pressure air oil atomizing burner is one of installation cost versus cost recovery through energy savings. The potential barriers for the sealed-in gas burners are more involved. 
The installation cost of sealing in the burner would be very small. However, some furnace operators are concerned about overheating of the burner tube and the refractory burner block. The concern is that the higher temperatures will lead to premature failure of these critical components. In fact, some furnace operators have tried sealing in gas burners and then have unsealed them later when they experienced problems. (a) This is offset by the fact that many manufacturers operate sealed-in burners with no apparent problems.

\subsubsection{Oxygen Enrichment}

Although oxygen enrichment of combustion air is a recognized energy-saving technology, the U.S. glass industry primarily considers it a means of extending the life of an ailing furnace rather than a means of conserving energy. Used in this respect, it has the opposite effect if it prolongs the life of an energy-inefficient furnace. Conventional methods of producing oxygen-enriched air (pressure-swing adsorption (PSA) and cryogenics) are energy-intensive and expensive for the small user. However, the U.S. Department of Energy and the Gas Research Institute are currently funding separate programs to develop lowcost oxygen generation systems that can be installed on site.

The U.S. Department of Energy is funding A/G Technology to develop a hollow fiber membrane cartridge which is designed to increase the oxygen content of air to about $35 \%$. The membrane system can be operated in a vacuum or a pressurized mode. However, the vacuum mode is preferred because it requires significantly less power and because its capital and operating costs are lower. In the vacuum mode (shown in Figure 4.2), a centrifugal blower pressurizes the feed air to 1 to 2 psig. The feed air passes through prefilters and enters the membrane unit. Oxygen preferentially permeates the membrane into the hollow center of the fibers. The oxygen enriched air leaves the cartridge and enters the combustion chamber. The oxygen-depleted (nitrogen-rich) air leaves the cartridge as the reject stream. Table 4.3 compares the energy requirements, the operating costs, and the capital costs of hollow fiber, PSA, and cryogenic oxygen enrichment systems.

(a) Personal communication with S. E. Fuller, Process Development Superintendent, PPG Industries, Meadville, Pennsylvania. 

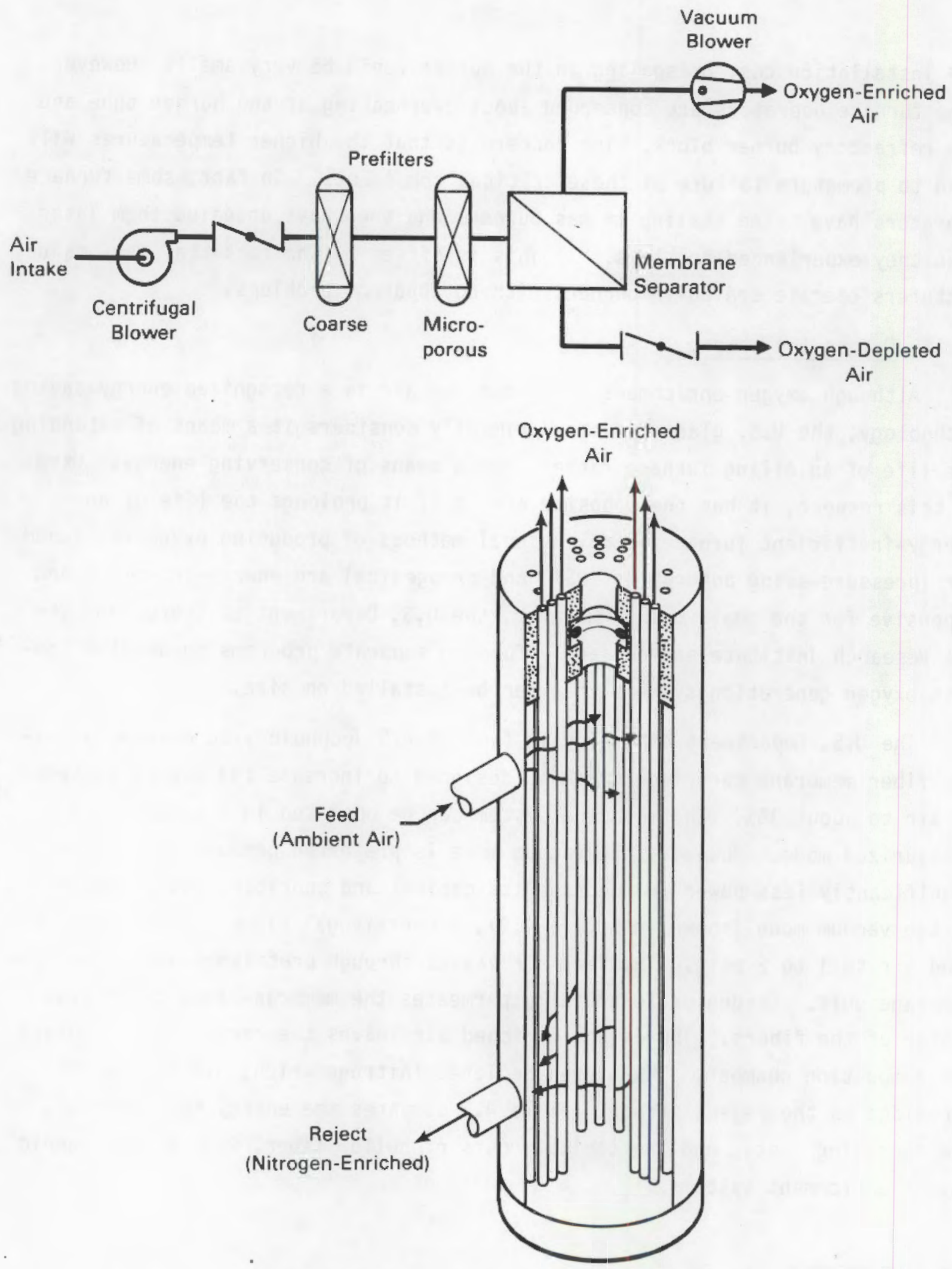

FIGURE 4.2. Hollow Fiber Oxygen Enrichment System (Gollan and Kleper 1984a) 
TABLE 4.3. Comparison of PSA, Cryogenics and Hollow Fiber Oxygen Enrichment (Gollan and Kleper 1984) ${ }^{(a)}$

\begin{tabular}{|c|c|c|c|}
\hline & PSA & Cryogenics & Hollow Fiber \\
\hline $\begin{array}{l}\text { Power Requi rements } \\
\text { (kWh/ton) }\end{array}$ & 290 & 390 & 175 \\
\hline $\begin{array}{l}\text { Operating Costs } \\
\text { (\$/ton) }\end{array}$ & 32 & 48 & 25 \\
\hline $\begin{array}{l}\text { Capital Costs } \\
\text { ( } \$ 1000 / \text { ton) }\end{array}$ & $25-70$ & (b) & $16-27$ \\
\hline
\end{tabular}

(a) Figures are based on a system producing 10 tons/day of air enriched to $35 \%$ oxygen.

(b) Capital costs for cryogenics are available only beyond a production capacity of 100 tons/day. It is estimated that in the 1 to 20 ton/day range that the capital costs of cryogenics would equal or exceed the capital cost of PSA.

Xorbox Corporation, with support from GRI, has developed a low-cost oxygen generation system which is based on an adaptation of a pressure-swing adsorption process. Air is introduced under pressure to a packed bed of synthetic zeolite. The zeolite adsorbent removes most of the oxygen and produces an oxygen-rich stream of up to $95 \%$ purity. The Xorbox process is less expensive than the conventional PSA process because it:

- uses less zeolite adsorbent by operating with a single absorbent bed and surge tank rather than multiple beds

- uses a blower rather than a compressor to achieve the required bed pressure (Glass Industry December 1984).

Energy-Saving Potential

0xygen enrichment increases the flame temperature of natural gas, thereby improving effective heat transfer to the glass batch and cutting down on energy rejected in the flue gas. Figure 4.3 shows the percent fuel savings as a function of the percentage of oxygen in the combustion air.

In the last few years Liquid Air Corporation has installed 50 oxygenenrichment facilities on glass plants. Most of these glass melters have been 


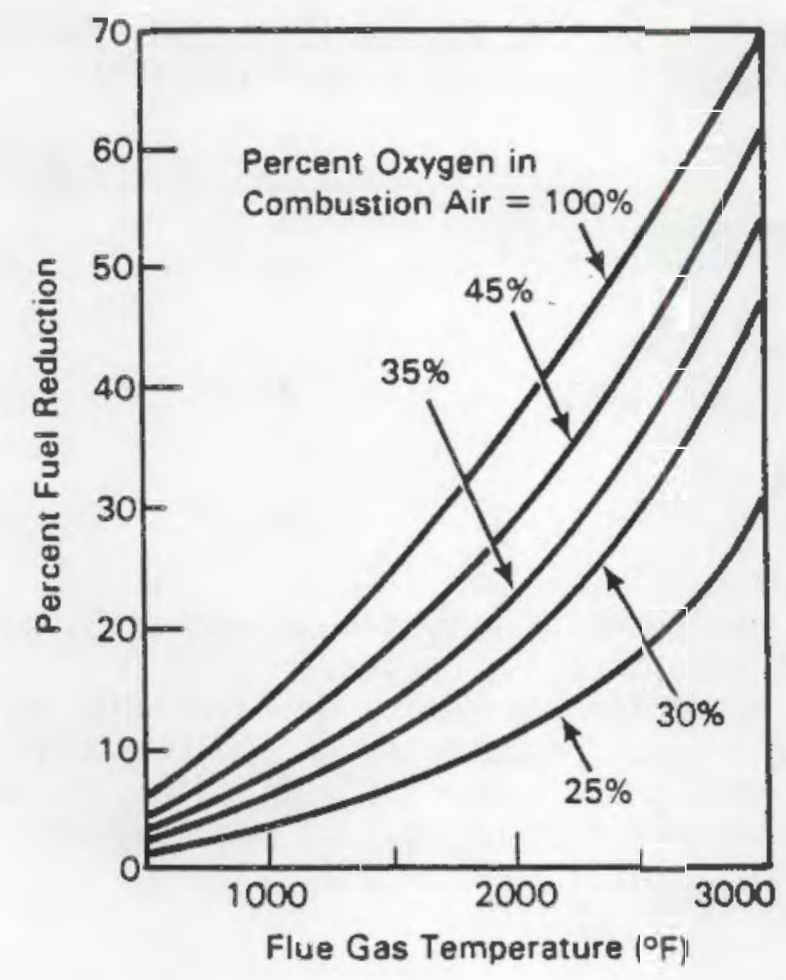

FIGURE 4.3. Natural Gas Savings Versus

Percentage of Oxygen in

Combustion Air (Gollan

and Kleper 1984b)

small pot furnaces. However, one facility was a 330-ton-per-day regenerative container furnace. On this furnace the pull was increased to 373 tons per day and the specific energy use decreased $7 \%$ from 5.2 million Btu per ton to 4.8 million Btu per ton. 0xygen consumption amounted to 780 cubic feet per ton.

The Xorbox system is currently being tested at Ford Motor Company's Glass Division in Nashville, Tennessee. It is expected to increase melting energy efficiency by up to $20 \%$ and increase output by as much as $40 \%$ (Glass Industry December 1984).

This technique is used in Europe with some success. However, in the U.S. it is primarily used to extend the life of old furnaces. We expect that nearterm application of oxygen enrichment may save 1 to 2 trillion 8 tu/year through increased pull rates. If ongoing efforts to develop low-cost, oxygen-enriched 
air sources are successful, the results in the glass industry would be dramatic. We estimate that on the order of $10 \%$ to $15 \%$ of the melting energy in the entire industry could be conserved. This would save 20 to 30 trillion Btu/year at 1985 production levels.

\section{Possible Barriers}

The high cost of oxygen to the small-volume user and uncertainty regarding the actual effects of oxygen enrichment on process parameters and equipment have limited industry adoption of the practice.

\subsubsection{Fue? -Switching}

Low-Btu synthesis gas produced from gasifying coal was used to fire the first regenerative furnace developed in 1856. Since that time, as supplies of natural gas became more abundant and less expensive, the industry has come to rely primarily on natural gas. Most glass producers in the U.S. have the capability of switching from gas to oil, and during shortages in the early seventies low-sulfur oil was often substituted for gas. Today, natural gas remains the fuel of choice because of its clean-burning characteristics.

Fuel-switching alternatives that have been investigated include: direct firing, coal-fired hot gas generation, coal gasification, either on site or at a central utility (Oak Ridge 1980, Harper et al. 1982) and coal-0il slurries. None of these has seen commercial application in the U.S. The primary barrier appears to be cost. In addition, direct firing is considered undesirable because the fly ash and other contaminants associated with coal combustion could impact glass quality. With the cost of pollution control and the availability of electric melting technology, it appears unlikely that conversion to coal will be considered as a viable alternative by the glass industry.

\subsubsection{Electric Melting}

All-electric glass melting has found its most significant use in the fiberglass sector of the glass industry. Electric melters are used to a $1 \mathrm{im}-$ ited extent by the container and pressed and blown glass segments and not at all by the flat glass segment. Many glass furnace engineering firms have developed experience in designing and building all-electric glass furnaces (Burwell 1983). 
Although there are no technical limitations on size, the largest allelectric furnace to date is a 240 -metric ton/day furnace operated by Certainteed in Athens, Georgia. (a) Penberthy (1984) reports the following advantages of electric furnaces over combustion furnaces:

- reduced emissions

- reduced loss of volatile constituents

- improved glass uniformity

- reduced product loss due to stones

- greater tolerance to batch errors

- easier to return to efficient production after holiday turndown

- faster furnace rebuilds

- maintenance of full-rated furnace output throughout the campaign

- small space requirement

- potential for recovery of a relatively pure carbon dioxide byproduct. Energy-Savings Potential

Electric furnaces are upwards of $65 \%$ thermally efficient compared to an average thermal efficiency of about $35 \%$ for regenerative, fossil-fired glass furnaces (Berg 1982, Penberthy 1984). Thus, while there is a clear opportunity for direct energy savings at the manufacturing facility, all-electric melting may result in a net increase in fuel use once the conversion efficiency of the utility is taken into account. Thus, it is difficult to consider this an energy-conservation technology. It is more of a fuel-switching and pollutionreduction technology.

\section{Possible Barriers}

The major barriers to the widespread adoption of all-electric melting are: 1) reduced refractory life, 2) the higher installed cost of electric melters relative to gas-fired melters, and 3 ) the price of electricity. Electric melting cannot be used with glass formations which which are oxidizing and contain metals that attack the molybdenum electrodes. Tin oxide electrodes, used for highly oxidizing glasses, are very expensive. While some members of the glass industry advocate the widespread use of all-electric melting, others

(a) Personal communication, Carl Hibscher, Toledo Engineering, Toledo, Ohio. 
appear to have three basic reservations: 1) electric furnaces cannot provide large capacity, 2) electric furnaces are less flexible with respect to rate of production, and 3 ) electric furnaces are inflexible in changing composition and color of the glass produced (Berg 1982). The first two reservations have been contradicted by field experience and, while all-electric melting at high capacity has not been demonstrated, no technical barriers appear to limit capacity increases. The adoption of all-electric melters by the flat glass industry is further impeded by the fact that the current production equipment in this industry is relatively new and is not likely to be replaced in the near term.

Other developments that can improve the performance of all electric glass melting are discussed below.

\section{Corning's Molybdenum-Lined Melter}

Corning Engineering has developed a molybdenum-lined electric melter that is expected to have a service life comparable to a gas melter. A 10-ton-perday molybdenum-lined melter has realized a thermal efficiency of $75 \%$ with a clear opal borosilicate glass. Melting of lowexpansion borosilicate glass requires temperatures of up to $1800^{\circ} \mathrm{C}\left(3240^{\circ} \mathrm{F}\right)$. It is difficult to achieve these temperatures at high efficiency with a long furnace life in an oil-or gas-fired melter. Electric melting is capable of attaining these high melting temperatures. Corning is upgrading existing Vermel furnaces where applicable. The molybdenum-lined melter is not compatible with lead glasses or glasses containing arsenic or antimony or any other oxiding glass because these materials attack the molybdenum liner (Palmquist 1984).

\section{Energy-Savings Potential}

Table 4.4 shows the energy consumption data for the small developmental molybdenum-lined melter with three types of glass. The projected energy savings of the 42-ton-per-day molybdenum-lined melter over the 30-ton-per-day Vermel melter it will replace is significant. This melter is expected to consume an estimated average $650 \mathrm{kWh} /$ ton over its six-year life compared to 885 $\mathrm{kWh} / \mathrm{t}$ on consumed by the Vermel furnace. This represents a savings of about $27 \%$. Another advantage is the exceptionally low corrosion rate of the furnace. 
TABLE 4.4. Melting Experience with the Molybdenum-Lined Melter (Palmquist 1984)

\begin{tabular}{|c|c|c|}
\hline Glass & $\begin{array}{c}\text { Rate } \\
\text { Tons/Day } \\
\text { (ft }{ }^{2} / \text { ton) } \\
\end{array}$ & $\begin{array}{r}\text { Energy } \\
\mathrm{kWh} / \text { ton } \\
\end{array}$ \\
\hline $\begin{array}{l}\text { Borosilicate } \\
\quad\left(55 \times 10^{-} \text {Exp }\right)\end{array}$ & $\begin{array}{l}10 \\
(1.4)\end{array}$ & 762 \\
\hline $\begin{array}{l}\text { Borosilicate } \\
\quad\left(32 \times 10^{-} \text {Exp }\right)\end{array}$ & $\begin{array}{r}8.75 \\
(1.6)\end{array}$ & 820 \\
\hline Wool Fiber & $\begin{array}{l}11.2 \\
(1.25)\end{array}$ & $750-795$ \\
\hline $\begin{array}{l}\text { Al umino-Silicate } \\
\text { CGW Code } 1720\end{array}$ & $\begin{array}{l}8.75 \\
(1.6)\end{array}$ & 785 \\
\hline
\end{tabular}

\section{Possible Barriers}

The major technical barrier is that the furnace cannot be used with glass formulations containing metals and oxides that attack the molybdenum liner. Other barriers include the lack of widespread experience with the melter and its cost over existing technologies. The full-scale demonstration now underway should answer many questions regarding actual furnace life and energy performance. The cost factor remains a potential barrier on a plant-by-plant basis.

\section{Automatic Tap Changing Transformers for Electric Melters}

The development of electric power supply systems for glass melters has evolved from the early tapped transformers to automatic tap changing transformers with SCR power control. The early systems were difficult to control and were used mainly for boost. The new auto-tap systems with SCR control provide accurate proportional control of power and temperature and a high power factor (Wetzel 1983).

\section{Energy-Savings Potential}

There are no direct energy savings in terms of kilowatt-hours of energy. However, because the actual power (KVA) measured by the utility is reduced, significant cost savings can accrue. These savings may provide additional incentive to glass manufacturers to adopt electric melters. Most utilities 
charge their industrial customers for both the energy used and the rate at which it is used (demand charge). As an example, if a furnace is using $1000 \mathrm{~kW}$ at a power factor of 0.80 ; the actual power will be $1000 / 0.80=1250 \mathrm{kVA}$. At a power factor of 0.94 the actual power is $1000 / 0.94=1064 \mathrm{kVA}$. The difference in the actual power between these two power factors in this case would be 186 kVA.

\section{Potential Barriers}

Magnetics Company of Sandy Lake, Pennsylvania has installed on the order of 10 to 20 auto-tap transformers for the major glass companies. Interest in the auto-tap system is growing and they expect more sales in the future. The payback of an auto-tap transformer based on a reduction of demand charges alone is between two to five years depending on the specific application. The improved control of power output and glass temperature is valuable but is not included in the above payback calculation. The major barrier will likely remain cost versus return considerations and the fact that the replacement of an existing system will be done only during a rebuild. (a)

\subsubsection{Dual-Depth Melter Design}

The dual-depth melter modification is shown in Figure 4.4. The purpose of the modification was to increase the capacity of a 693-square foot furnace from 255 tons per day to 275 tons per day without the requirement for additional electric boost. The Kerr Glass Corporation's Millville "C" plant was modified through consultation with Sorg Engineering of West Germany. The melter's holding capacity was increased from 200 to 241 tons. The intent of the design is to reduce bottom "short-circuiting" and to allow more efficient heat transfer in both fossil-fuel and electric heat inputs.

\section{Energy-Savings Potential}

Significant productivity and energy efficiency gains were realized by the modified melters. For the same gas and electric boost input as the previous campaign, $18 \%$ more tonnage could be pulled with no loss of product quality.

(a) Personal communication with Fred Wetzel, Magnetics Company, Sandy Lake, Pennsylvania. 


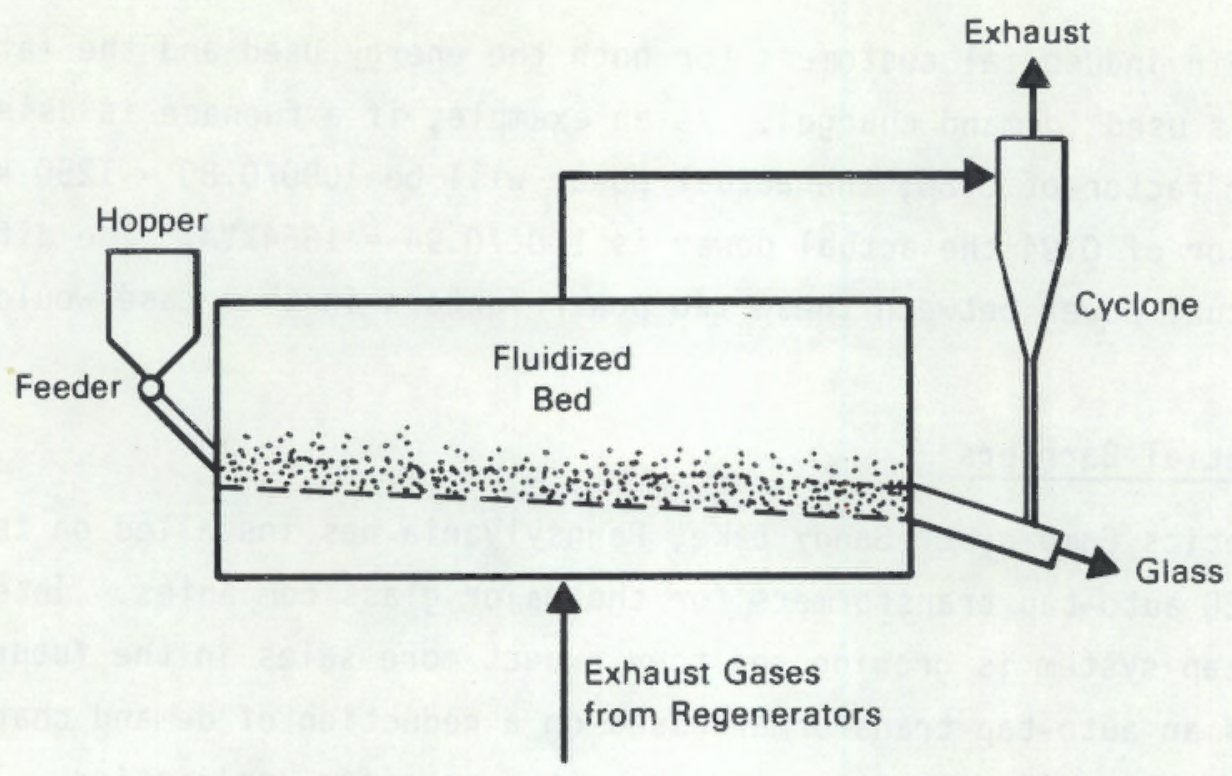

FIGURE 4.4. Dual-Depth Melter (Ross 1984)

For the same bridgewall temperature and boost level (conditions which would duplicate melter life), $10 \%$ more tonnage could be pulled. At lower tonnages with no electric boost, $30 \%$ more tonnage could be pulled at the same bridgewall temperature (Ross 1982).

The dual-depth melter design is primarily a method of increasing the melter capacity without increasing electric boost. Although the main purpose is not energy conservation, the design achieves that end. The dual depth melting technique is essentially a combination fossil-fired and electric melter. In that sense, the actual energy savings on a global sense cannot be quantified.

\section{Possible Barriers}

The dual-depth modification is costly and is considered to be of questionable value for new furnace construction. However, the glass container industry is contracting and there is no new furnace construction at present. This technique may be a way to retire inefficient furnaces at a given bottle plant and make up some of the lost capacity by increasing the capacity of one of the larger and better-designed furnaces. Another problem was that there were a number of complicating factors associated with the installation of the 
dual-depth designs. An improved control system with an in-glass thermocouple was installed along with the dual-depth system. However, the extent to which this control system contributed to the energy savings apart from the dual-depth design was not determined.

\subsubsection{Improved Refractories}

Many of the advances in the glass industry can be linked to the development of advanced refractories. Improved refractories allow a wider range of glass formulations, higher temperatures and better glass quality. The glasscontact refractories of a glass furnace slowly dissolve into the glass over time. As long as they dissolve and go into solution, there are few defect problems. Sometimes the localized chemistry difference can result in the formation of a bubble or seed. Chemistry differences also can result in localized differences in the index of refraction (cord). Cord is particularly unacceptable for flat glass. When refractory particles remain undissolved a stone in the final product results.

In addition to the different formulations for refractories, there are different ways to manufacture the blocks. High-temperature glass contact refractories are electrically fused and cast. Upon cooling, the block will shrink by as much as 9 to $11 \%$. This leaves voids in the block that can be opened as the block is corroded away by the glass. A number of techniques have been developed to minimize the voids in the refractory block. Essentially void-free blocks can be manufactured out of any refractory material. The void-free blocks are more costly and are usually used only in critical high-wear furnace areas. These high-wear areas include the doghouse corners, throat, port floors, electrode blocks and sidewalls (Sohio Engineered Materials Company 1973).

The use of a metal lining in glass melting furnaces, while not commonplace, does exist. The Moly-Melter represents the latest development in furnace lining. It is a significant departure from traditional furnace engineering. Platinum is used to line small electric melters designed to produce ultra-pure optical fibers, optical glass and other specialty glasses. While these successful applications exist, they are specialized in nature and do not apply to the entire glass industry at this time (Glass Industry April 1985). 
Further improvements in refractories are likely to allow increased energy and capital savings with improvement or no loss of product quality. Hightemperature, high-performance ceramics are currently the subject of great world-wide attention. The improvement in refractories affects energy conservation in three ways. Improved refractories can be run hotter and thus be more heavily insulated. Improved refractories minimize glass quality problems and allow enhanced quality at existing energy levels. Improved refractories mean longer furnace campaigns. The longer the campaign the more important the energy consumption over the campaign becomes. Thus, the furnace must be built to last and to operate efficiently for a long time (Darbon 1983).

\section{Energy-Saving Potential}

The better the refractories, the better the potential energy performance of the furnace over its life. We estimate that the widespread use of high-quality refractories could result in savings of about 5 to $10 \%$ of the melting energy used in the glass industry. In the near-term, savings are estimated to range from 5 to 10 trillion Btu/year. As further improvements and cost reductions occur, allowing more widespread application, savings on the order of 10 to 20 trillion Btu/year are estimated.

\section{Possible Barriers}

U.S. industry is now able to make very-high-quality refractories. The main barrier to their widespread use is the cost. Research to reduce the manufacturing costs of high-quality refractories could lead to more widespread use.

\subsubsection{Melt Homogenization}

Energy savings, boosted capacity, and improved product quality result from improved mixing within the glass melt. Many methods are currently being used to enhance the natural convection resulting from the temperature gradient established along the melter.

Compressed air is bubbled up from the bottom of the melter in order to enhance convection flow within the glass melt. Bubbling causes the cold glass to rise to the surface where it can absorb heat from the flame. These systems are installed such that the bubbling enhances the main convection current in the melter and increases local turbulence in the glass flow. Both of these 
mechanisms improve the homogeneity of the glass and reduce fuel consumption. The use of pulsed, rather than continuous, bubbling can space the bubbles far enough apart vertically to prevent bubble coalescence which can create seeds in the glass.

Although electric boosting is primarily seen as a means of increasing the maximum tonnage output of a melter, it also has the advantage of reducing fossil fuel use and the stack emissions associated with fossil fuel combustion. Electric-boosting systems can be retrofitted without shutting down the furnace.

Electrodes can be placed in such a way as to alter or enhance the convection currents that would occur with fossil-fired heating alone. This can improve heat transfer and product quality. The best opportunity for influencing glass flow control occurs when the electrodes are inserted through the bottom of the melter. However, this is more difficult than side wall insertion.

\subsection{WASTE-HEAT RECOVERY}

Despite the fact that a majority of glass melting furnaces are regenerative or recuperative, between 1.0 to 1.4 quads of unrecovered energy are lost from glass melting operations each year (Wilfert 1984). About half of this amount is rejected in melter exhausts while the other half is due largely to radiant heat losses. Glass batch preheating, improved regenerators, recuperators and secondary recovery from regenerator exhausts are technologies designed to recover some of this wasted heat.

The glass industry has a great deal of experience in regenerator operation. Potential improvements include the Veitscher and Cruciform packings, and high-temperature silicone elastomer sealing of regenerator walls. These improvements will likely make gradual inroads into glass industry practice. We estimate that about 5 to $10 \%$ of the melting energy used in regenerative furnaces could be conserved in the near-term and perhaps 10 to $20 \%$, with continued development, in the long-term. 


\subsubsection{Glass Batch Preheater}

Glass batch preheating has undergone extensive study by the glass industry. The basic technological approaches to batch preheating include: 1) preheating batch by direct contact with the flue gas, or 2) indirect preheating.

The major benefits associated with direct-contact preheating include high rates of heat transfer and an ability to capture particulate matter in flue gases. Direct contact preheating can occur with loose batch materials or the batch materials can be densified (pellets or briquettes are formed from the loose batch material) prior to preheating. At present, direct-contact preheating technologies are limited to batch materials. Cullet is not heated in this approach because of the vast differences in particle size and density between the cullet and the batch.

With indirect preheating, batch flowing on the tube side of a heat exchanger is preheated by flue gases flowing on the shell side. This technology can accommodate loose batch and cullet in any ratio. However, the heat transfer effectiveness is below that of direct-contact preheating.

Thermo Electron Corporation of Waltham, Massachusetts, in conjunction with Holcroft-Loftus and Toledo Engineering Co. Inc., has developed a system utilizing a fluidized bed to preheat glass batch with furnace exhaust gases. Research and development on this system, sponsored by the Gas Research Institute and the Southern California Gas Company, has been underway since 1978.

A conceptual design of a fluidized-bed glass batch preheater installed on a regenerative end-port furnace is shown in Figure 4.5. Mixed glass batch is introduced to the preheater where it is fluidized by furnace exhaust gas. The batch is preheated to between 700 and $900^{\circ} \mathrm{F}$ as it passes through the fluidized bed. It flows across the bed and over a weir to a standpipe with a special screw feeder that meters the preheated batch into the batch charger. The fluidization of the batch promotes mixing and homogenization of the batch and exhaust gas particulate capture.

\section{Energy-Savings Potential}

Testing to date indicates that the direct-contact Thermo Electron system can save up to $20 \%$ of the energy used to melt glass batch (Cole 1984). As 


\section{Before Modification}

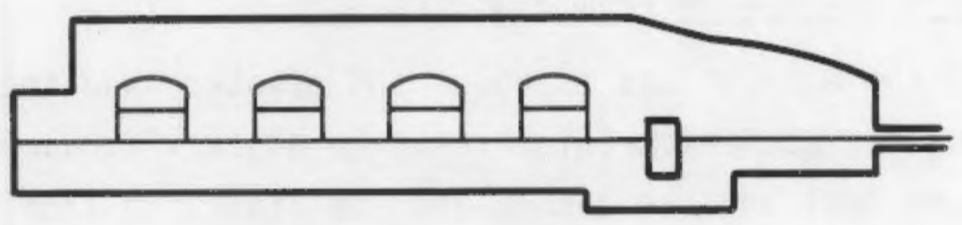

After Modification

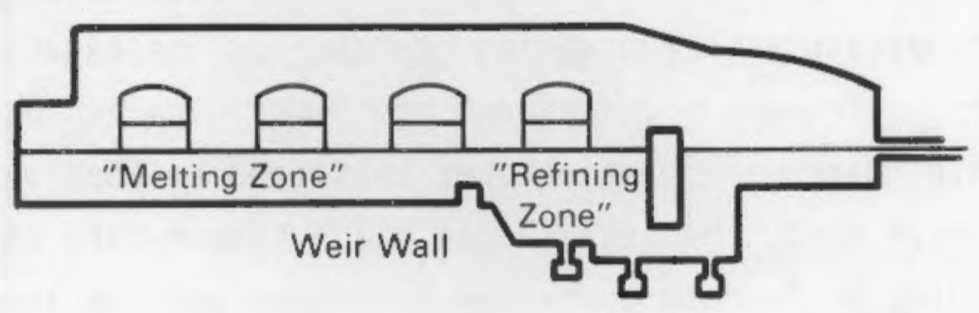

FIGURE 4.5. Fluidized-Bed Glass Batch Preheater Concept (Doyle and Donaldson 1984)

cullet loads increase, (as is the case with most container industry applications) the energy savings from preheating loose batch contributes less to the furnace energy balance.

It is estimated that indirect preheating systems may save 10 to $15 \%$ if both batch and cullet are preheated. (a) We estimate energy savings could range from 20 to 30 trillion Btu/year.

\section{Potential Barriers}

The economics of retrofitting batch preheating systems into existing plants could be somewhat of a barrier to their widespread use. However, preliminary economic analyses by Cole (1983) indicates that a 2-year payback may be achieved in some locations. Space limitations in some plants may preclude their use. The results of the Thermo Electron tests will indicate whether or not plugging of the small holes in the grating over which the batch flows by dirty furnace gases occurs.

(a) Personal communication, Associated Technical Consultants, Toledo, Ohio. 


\subsubsection{Excess Heat Extraction From Regenerators}

The mass of the exhaust gas is about $18 \%$ greater than the mass of combustion air required for stoichiometric firing in a glass furnace. The additional gas comes from the fuel and the carbon dioxide liberated from the glass batch. Thus the mass of exhaust heating the regenerators is always more than the mass of combustion air removing heat from the regenerators. Due to this imbalance plus the higher heat capacity of the exhaust, the flue gas exhaust leaves the stack at high temperatures. Recovering energy from the exhaust after it leaves the regenerators is fraught with several problems. The exhaust gas is very dirty and contains corrosive particulates that tend to foul and corrode heatexchange surfaces. Also, the exhaust gas has a temperature on the order of 600 to $1200^{\circ} \mathrm{F}$ depending on furnace operation. Further cooling in a heat-recovery device could reduce the temperature below the acid dew point and further increase corrosion.

Nelson (1985) describes a method to balance the mass flow rates of the combustion air and exhaust gas and then extract the excess high temperature combustion air from the top of the regenerator. This heated combustion air has a temperature on the order of $2000^{\circ} \mathrm{F}$ and is a relatively clean gas stream. Patent 4,516,934 describes how this hot clean gas stream can be continuously extracted from a regenerative furnace without the use of high temperature valves.

\section{Energy-Savings Potential}

There are no estimates of the energy savings that would accrue from the use of this technique in the literature. If this system were adapted with an elaborate control system, we estimate that the energy recovery/regenerator efficiency could be improved by up to $10 \%$. This would not be a direct savings. The high-temperature air stream would have to be utilized to realize the savings.

\section{Possible Barriers}

The main barriers facing this system are that its capital cost and efficacy are unproven. If the high-temperature air stream could be recovered without significant impact on furnace operation, there is still the question of its 
use. If the air could be used directly in an annealing or tempering lehr, additional capital costs could be minimized. However, if the high-temperature air stream were too dirty for direct application, additional energy-recovery equipment would be needed.

\subsubsection{Reduction of Regenerator Air Leakage}

Air leakage into a regenerator reduces the performance of the regenerator and increases the energy consumption of the furnace. However, the regenerator wall leakage has the most significant adverse effect on fuel consumption. Llewellyn and Wei (1982) compiled the data in Table 4.5 showing typical values of air leakage in regenerative glass furnaces. The effect of air leakage on regenerator performance is shown in Figure 4.6. This figure was generated by the Air Research computer model GFURN (Llewellyn and Wei 1982).

The principal sources of air leakage are the reversing valve, the flue wall and the regenerator wall. The reversing valve leaks due to incomplete closure due to warpage, obstruction or refractory wear. The flue wall and regenerators develop leaks as a result of the thermal expansion and contraction of the walls and regenerator packing. The use of ceramic mortars and pastes to repair these cracks is not always satisfactory because the mortars are often air permeable and they also crack after a time. Richards (1984) describes a method of applying a silicone elastomer dispersed in water over the outer surface of a well insulated regenerator to reduce air leakage. The method is especially good for sealing around regenerator cleanout plugs. A silicone elastomer is applied in successive coats over the surface of the regenerator. Since sealing regenerator cracks must be done continuously, a major advantage is that the sealant can be applied to the hot surface of the regenerator during furnace operation. Three coats of the sealant reduce leakage by a factor of 8 to 10 .

\section{Energy-Savings Potential}

For every $4 \%$ reduction in air leakage there is approximately a $1 \%$ savings in fuel consumption (Llewellyn 1982). Thus, for the furnaces represented in Table 4.5, an energy savings of 2 to $10 \%$ could be realized. 
TABLE 4.5. Typical Air Leakage in Regenerators

(Llewellyn and Wei 1982)

$\mathrm{O}_{2}$ Content (\%)

\begin{tabular}{|c|c|c|c|}
\hline Source & Top of Regenerator & Bottom of Regenerator & $(q)$ \\
\hline Company A & $1.5-4$ & $4-101$ & $3-35$ \\
\hline Company B & 2.0 & $6^{(a)}$ & $12-30^{(a)}$ \\
\hline Company C & & & $15-20$ \\
\hline Company $D$ & 2.0 & 4 & 10 \\
\hline Company $\mathrm{E}$ & $2.0-3.0$ & $5-8$ & $28(b)$ \\
\hline Company $F$ & $1.0-3.0$ & 5 & 11 \\
\hline (c) & & & $35-45$ \\
\hline (d) & 3.0 & 6 & 20 \\
\hline (e) & & & 25 \\
\hline Company $\mathrm{G}$ & & & 25 \\
\hline & & & $14(g)$ \\
\hline & & & $3^{(h)}$ \\
\hline
\end{tabular}

(a) Downstream of reversing valve.

(b) Two-thirds of air leakage was from valve and flue wall.

(c) F. J. Nelson and J. D. Novak, "Data Requirements for Quantitative Analyses of Commercial Glass Melting System Energy Performance," Am. Ceram. Soc. Bul1. 59(11), 1141-44 (November 1980).

(d) S. Lutskanov, "Increasing the Efficiency of Glass Tank Furnaces by Making the Regenerative System Airtight," Glastek. Tidskr. 29(2), 39-42 (1974).

(e) J. Waitkus, "Rotary regenerative waste Heat Recovery for the Glass Industry," J. Can. Ceram. Soc. 33, 107-21 (1964).

(f) Brayt on Cycle Heat Recovery System Characterization Program Monthly Report No. 14, Report 80-16897(14), AiResearch Manufacturing Company of California, Torrance, April 1981, pp. 2-6.

(g) In regenerator.

(h) In reversing valve.

\section{Possible Barriers}

The application of silicone sealant to glass furnace regenerator walls as a method of reducing air leakage has been patented and the rights have been assigned to Owens-Illinois, Incorporated of Toledo, Ohio. There are no foreseeable barriers preventing Owens-Illinois from using this technique. Other firms would have to obtain the right to use this technique from Owens-Illinois. 


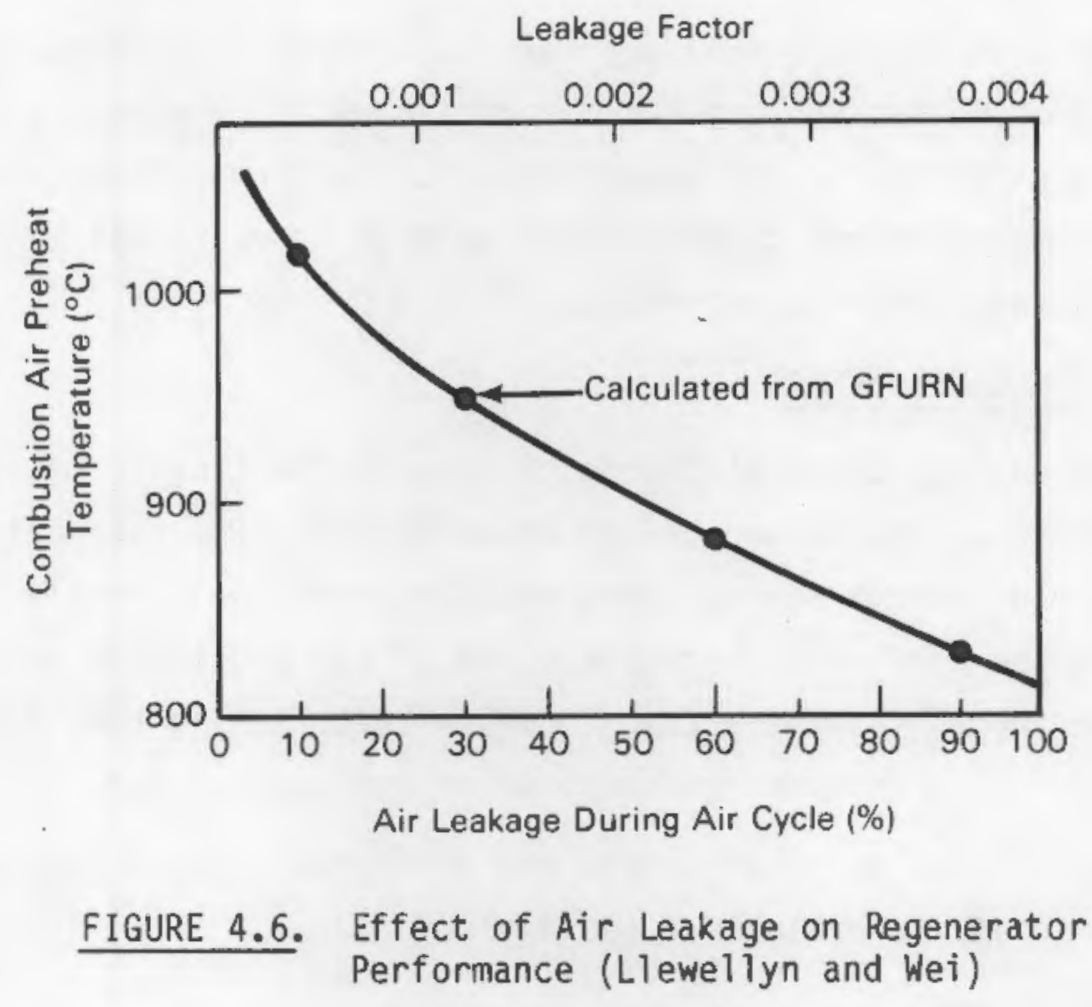

The silicone elastomer does have temperature limitations that restrict its use to we1l-insulated regenerators where the wall temperatures do not exceed $500^{\circ} \mathrm{F}$, the elastomer's temperature limit.

\subsubsection{Chimney Block Regenerator Refractories}

In 1972, Societe Europeenne des Produits Refractaires (SEPR) introduced the Cruciform (a) regenerator packing. The Cruciform is an " $X$ "-shaped fuse cast refractory block. The $X$-shaped blocks are stacked to form vertical channels or chimneys. Since 1972, Cruciform refractories have been installed in over 350 furnaces and some of the bricks have accumulated a total running time of over 10 years. One of the main advantages of the chimney-type packings over the conventional packings is their higher surface area per unit heat capacity. Conventional brick packings often have a dead zone in the center of the brick that does not contribute significantly to energy recovery. The chimney packings generally minimize this problem. The Cruciform block is made out of fuse

(a) Cruciform is a registered trademark of Societe Europeenne des Produits Refractaires, Paris, France. 
cast AZS (Alumina Zirconia Silica) whereas traditional regenerator packing is made out of magnesite for the upper checker reaches, chrome-magnesite for the mid-reaches and chromite for the lower reaches. Veitscher Magnesitwerke of Vienna, Austria manufactures chimney block made of conventional magnesite, chrome-magnesite and chromite materials.

Energy-Savings Potential

The energy savings associated with the use of the Cruciform packing in a new furnace and in a rebuild are on the order of 5 to $12 \%$, respectively (Moreau 1984). The rate of energy savings does not diminish significantly during the campaign due to the good wear characteristics of the Cruciform refractories. One of the other benefits of the Cruciform refractories is that they can extend the useful life or campaign duration of a glass furnace.

The energy savings associated with the Veitscher chimney packings is on the order of 3 to $7 \%$ (Scheiblechner 1984).

Possible Barriers

The fuse-cast Cruciform refractories have met with resistance in the United States due to their high capital cost. Their performance has been well established in European furnaces under a variety of conditions over the last 13 years, since fuel costs are higher and European glass manufacturers can obtain a reasonable return on investment.

The Veitscher refractories have been installed in four furnaces in North America to date. Due to their less costly materials of construction, there is less of a cost barrier. The veitscher refractories do not yet have great depth of testing on which to base firm cost/benefit estimates. However, this base of information is presently being developed.

\subsubsection{Recuperators}

Commercially available recuperators provide air preheat temperatures of about 1000 to $1400^{\circ} \mathrm{F}$. Expensive alloys, such as Inconel, must be used to withstand the high-temperature, corrosive exhausts. Even with these alloys, recuperators installed on insulation glass furnaces have experienced failures as a result of plastic deformation of the inner liner in the highly corrosive, 
high-temperature environment. Recuperators on low-alkali glass fiber (E glass) furnaces have exhibited longer lives than those on glass furnaces making glass fiber insulation because these exhausts are not nearly as corrosive as those from insulation glass melters.

Several firms are developing advanced recuperators with the goal of achieving higher effectiveness (higher preheat temperatures), better resistance to fouling and corrosion, or lower cost than current designs. Both metallic and ceramic configurations are under development. In addition, a moving granular bed recuperator has been examined in which ceramic marbles are used as a heat transfer medium between the flue gas and the air. If a large enough heat sink is available, the recuperator can cool flue gases below the dew point. This concept has the potential to reduce pollutants as well. (a)

\section{Energy-Savings Potential}

Figure 4.7 shows the fuel savings potential of recuperators as a function of the furnace exhaust gas temperature and the air preheat temperature available at the burner. The curves are based on natural-gas firing with $10 \%$ excess air. State-of-the-art recuperators can provide air preheat temperatures between about $1000^{\circ} \mathrm{F}$ and $1400^{\circ} \mathrm{F}$ from furnace exhausts ranging from about $1800^{\circ} \mathrm{F}$ to $2600^{\circ} \mathrm{F}$. Fuel savings of 20 to $30 \%$ have been reported with state-of-the-art recuperators installed on unit melters (Stark 1985). The improved materials and designs of advanced recuperator concepts offer the opportunity to increase air preheat temperatures above those achieved with current technologies. Higher preheat temperatures may make recuperation an attractive option for applications other than unit melters. We estimate that advanced recuperators may save 20 to $40 \%$ over current practice. We estimate an annual savings potential of 30 to 70 trillion Btu at 1985 production levels.

(a) Personal communication, Associated Technical Consultants, Toledo, Ohio. 


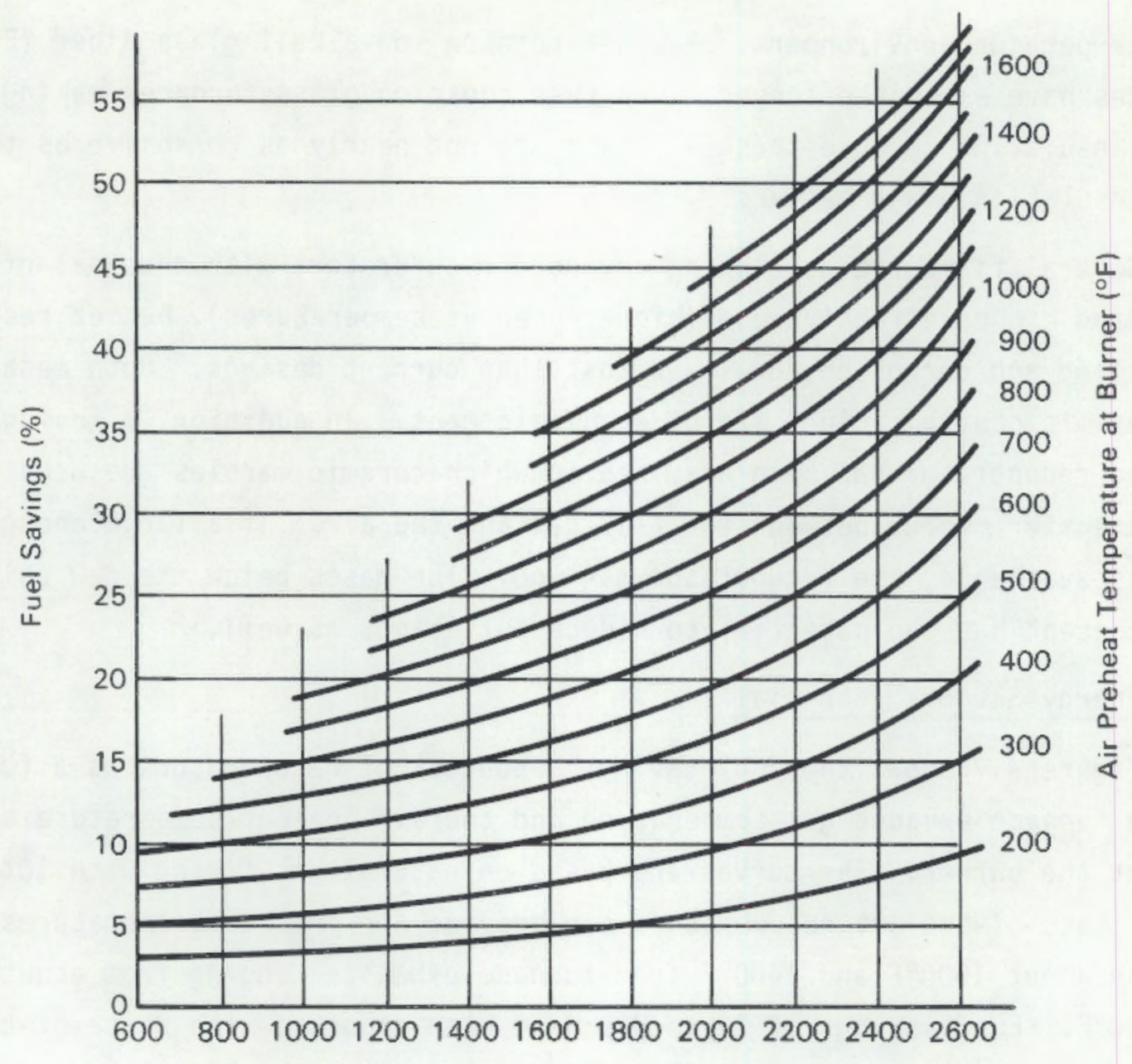

Flue Gas Temperature $\left({ }^{\circ} \mathrm{F}\right)$

FIGURE 4.7. Fuel Savings Potential of Recuperators (Courtesy of Energy Conversion Technology, Inc.)

\section{Possible Barriers}

Because of the direct contact between the combustion gases and the glass batch, the furnace exhausts are laden with particles and volatilized species from the glass. The particles consist primarily of sodium sulfate, sodium oxide, silicon dioxide, calcium oxide and unmelted cullet. The primarily liquid constituents are sodium sulfate and sodium trioxide (AiResearch 1982). The gas-phase constituents consist primarily of $\mathrm{NO}_{x}$ and $\mathrm{SO}_{2}$ ( $\mathrm{Sittig} 1977$, AiResearch 1982). 
These particles tend to collect on the hot face of the recuperator liner. The ultimate effect of the high temperature combined with the corrosive nature of the particles may include: 1) loss of recuperator effectiveness due to condensate buildup, 2) complete plugging, or 3) failure of the liner through corrosion (pitting or cracking). One company. reported that the use of a recuperator has cooled the exhaust gases to the point at which they become visible to the eye upon release to the atmosphere. Although emissions (both gas volume and total particulate) are lower than an unrecuperated furnace, the opacity of the exhaust from the recuperator is not in compliance with state standards. This may require the added expense of installing an electrostatic precipitator to achieve compliance.

To a certain extent, energy conservation and the continued use of unit melters is inconsistent. Beyond the application of recuperators and good housekeeping, the next step to improve energy performance is to change to a different type of furnace. The economic barrier for installation of recuperators is lessening as the industry gains experience. However, recuperators are an interim solution for an existing unit melter. Manville, Northwestern Glass and others are looking at installing electric melters to replace the unit melters.

\subsubsection{Thermochemical Recuperator}

The thermochemical recuperator (TCR), proposed by the Institute of Gas Technology (IGT), uses waste heat to increase the chemical energy of the fuel rather than to preheat combustion air as in conventional recuperator technology. In this concept, the exhausts exiting the melter at $2700^{\circ} \mathrm{F}$ are used to drive the reforming reaction in the thermochemical recuperator, in which methane and steam are converted to carbon monoxide and hydrogen. The $1850^{\circ} \mathrm{F}$ exhaust from the TCR is used to preheat furnace combustion air to about $1500^{\circ} \mathrm{F}$. The residual heat from the conventional recuperator $\left(1050^{\circ} \mathrm{F}\right)$ is used to generate steam in a waste heat boiler for use in the reformer (Haggin 1985). 


\section{Energy-Savings Potential}

The products of reforming (carbon dioxide and hydrogen) have a heating value $26 \%$ higher than that of methane (Haggin 1985). IGT estimates that the TCR system is potentially $40 \%$ more efficient than conventional recuperators, $30 \%$ more than efficient than state-of-the-art commercial recuperation, and $16 \%$ development.

The annual energy-sayings potential of the TCR is estimated to be about 35 to 70 trillion Btu/year at 1985 production levels.

\section{Possible Barriers}

No TCR has actually been built. Many technical issues need to be addressed through proof-of-concept studies. These issues include investigating the impact of the following on the ultimate heating value of the product:

1. the water-gas shift reaction ( $\mathrm{CO}$ and water react to form $\mathrm{CO}_{2}$ and hydrogen)

2. soot formation

3. other side reactions.

\subsubsection{Cogeneration}

Several approaches to cogeneration appear to have potential for saving energy when used with glass melting furnaces. These include steam Rankine bottoming cycles, Brayton cycles, and direct thermal-to-electrical conversion.

Steam Rankine Bottoming Systems

The steam Rankine system uses the waste heat rejected in furnace exhausts to generate steam in waste heat boilers. An example of a commercial steam Rankine system is shown in Figure 4.8. This system, developed by Heye Glass, a major West German container producer, uses unit melters in conjunction with an extensive energy-recovery system. The large vertical radiant recuperators are used to preheat combustion air. The convective recuperators downstream are used to generate steam. The steam is used for motive power and to drive a generator for electricity production. There are no facilities of this design operating in the U.S. However, Heye has been very successful in selling this 


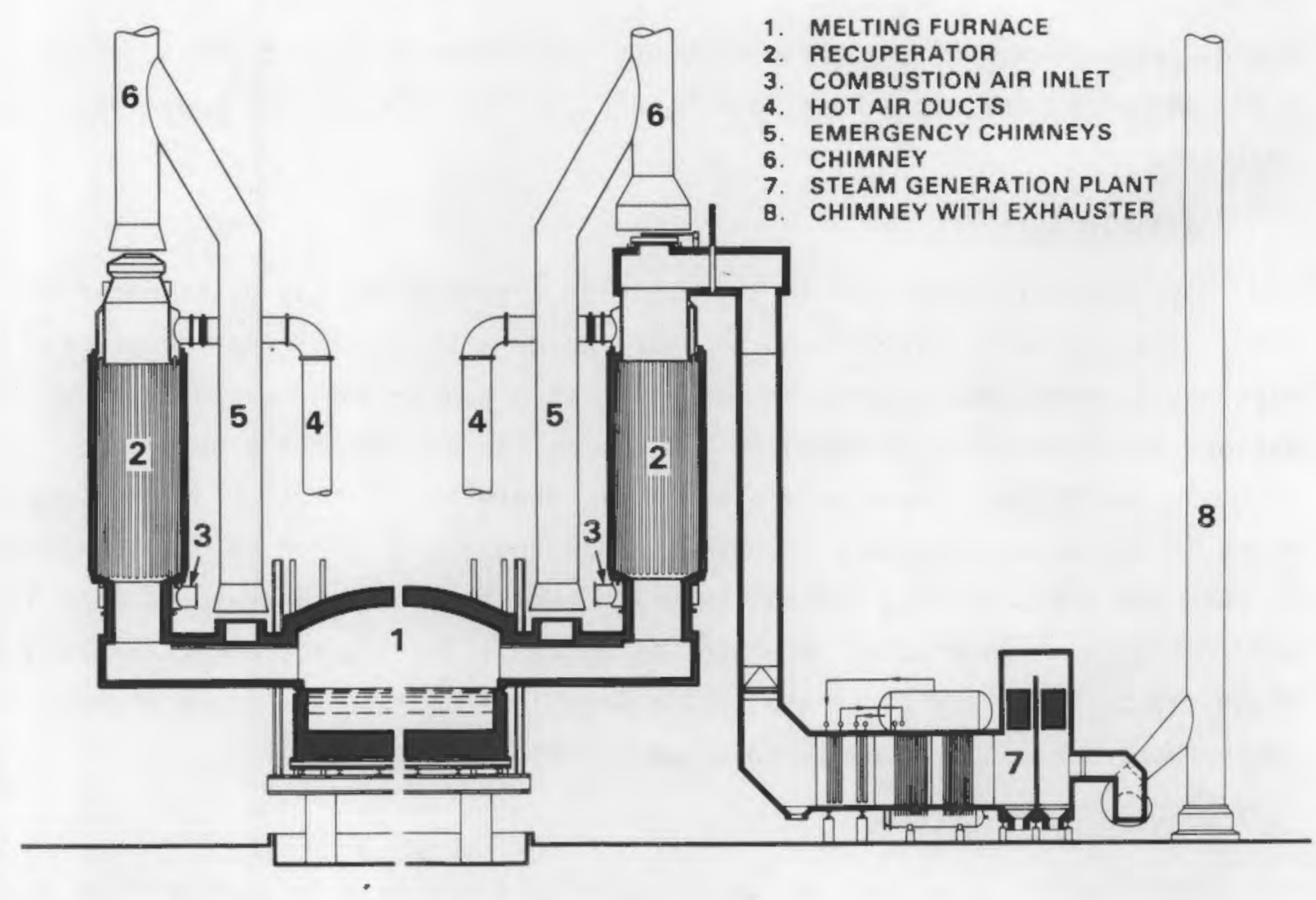

FIGURE 4.8. Heye Glass Melter

design in other parts of the world, particularly the third world. One of the reasons for this success has been the integrated cogeneration aspect of the glass plant. In many third world countries, electric power supply is often interrupted. This can be disastrous for a glass plant, so onsite cogeneration is an attractive aspect of the Heye design. The Heye design is also more popular in third world countries because it is less capital intensive than a regenerative furnace.

\section{Energy-Savings Potential}

The Heye glass melters will virtually always use more fuel per ton of glass produced. However, the process also produces steam and/or electricity. Heye has reported their net energy use--after subtracting the energy in the steam and electricity--to be on the order of 3.5 to 3.7 million Btu per ton of glass produced. This would represent about a 25 to $35 \%$ improvement in the 
energy productivity of a state-of-the-art container plant in the U.S. Assuming a $25 \%$ adoption rate, an annual savings of 10 to 15 trillion Btu could be realized.

\section{Possible Barriers}

Heye Glass leads the world in combining cogeneration and glass manufacture. They use unit melters and recover energy with metallic recuperators. Heye has enjoyed good success in marketing this approach in less-developed nations where electricity supplies are not reliable. Despite a number of attempts to interest American glass makers, there are no similar systems operating in the U.S. The basic problem in applying cogeneration to glass melting is that the glass melting process requires very high temperatures and that usually relegates cogeneration to bottoming cycles. The exhaust from typical U.S. glass plants is fairly dirty and cyclic both in flow rate and temperature. These factors are not amenable to an efficient bottoming cycle.

Brayton Cycle Systems

Both positive pressure and subatmospheric Brayton cycle cogeneration systems have been investigated for glass furnace application. In the subatmospheric Brayton cycle, the flue gases exiting the furnace regenerators are expanded through a radial inflow turbine to generate power. The turbine exhaust gases are then passed through a metallic, plate-fin heat exchanger at subatmospheric pressure to preheat the furnace combustion air. In the positive pressure Brayton cycle, the regenerator exhausts first pass through a ceramic tube heat exchanger to transfer heat to compressed air. The heated, compressed air is then expanded in a gas turbine and the turbine exhaust is used as supplementary combustion air in the furnace (Wei, Williams and Llewellyn 1981 and Hnat and Coles 1984).

\section{Energy-Savings Potential}

A feasibility study of a positive pressure Brayton cycle system on a small side-port soda-lime glass furnace indicated that a net power output of about $140 \mathrm{~kW}$ and a fuel savings of about $2.6 \%$ from supplemental air preheat was 
achievable (Hnat and Coles 1984). The furnace regenerators in this case were exhausting between 733,000 and $1,107,000 \mathrm{scfh}$ at temperatures between 750 and $850^{\circ} \mathrm{F}$ (Hnat and Coles 1984).

\section{Possible Barriers}

AiResearch tests of a subatmospheric Brayton cycle system indicated that serious deposition and erosion problems occur in the turbine and the secondary heat exchanger. However, Mitre Corporation has suggested that using magnesium additives to raise the melting point of the particulate in the exhaust may make any subsequent deposits dry and friable (Boyum 1982). The positive pressure Brayton cycle system is not considered a viable option in the near-term because the ceramic industry would have to develop the capability of providing the necessary heat exchanger tubing and the projected cost of this tubing is thought to make the concept uneconomical (Boyum 1982).

Direct Thermal-to-Electrical Conversion

Thermionics and the sodium heat engine are advanced concepts which offer the opportunity to produce direct current from high-temperature heat sources. Thermionic diodes accept heat at high temperatures in the furnace combustion chamber. The heat liberates a flow of electrons at the cathode. The sodium heat pump utilizes the heat in furnace exhausts. The heat raises the temperature and pressure of the sodium working fluid. As sodium ions enter the solid Beta"-Alumina electrolyte a flow of electron (direct current) is produced. A 55 watt prototype sodium heat engine has been developed and a 100 watt engine is currentiy under construction. (a) Preliminary cost estimates indicate that the sodium heat engine could be mass produced at a cost of about $\$ 100 / \mathrm{kWe}$. (b)

Energy-Savings Potential

Thermionic devices operate with normal efficiencies in the 8 to $11 \%$ range

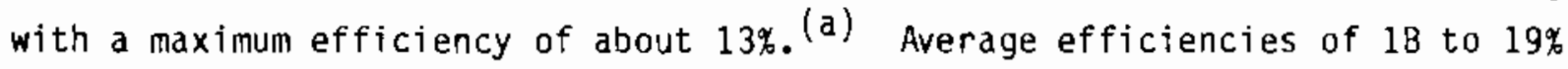

(a) Personal communication, John Eustis, U.S. Department of Energy, Washington, D.C.

(b) Personal communication, Dr. Thomas Hunt, Ford Motor Company, Dearborn, Michigan. 
have been demonstrated with the prototype sodium heat engines; near-term efficiencies of $30 \%$ and long-term efficiencies of $42 \%$ are expected to be achievable (hunt and Weber 1982).

\section{Possible Barriers}

The engineering hardware for direct thermal-to-electrical conversion technologies are still in the early stages of development. Considerable development will be required to prove the operating performance, reliability and economics of these systems for commercial application.

\subsection{FORMING AND POST-FORMING}

State-of-the-art technologies are available to the container, flat and pressed and blown segments of the glass industry which can significantly reduce the energy consumption of forming and post-forming operations. However, because the energy use of these operations is small relative to overall plant energy use, the impact of the widespread adoption of these technologies is sma11. We estimate that the industry-wide adoption of state-of-the-art forehearths, lehrs, tempering furnaces, curing/baking ovens, and variable-speed controls may result in an annual energy savings of about $3 \%$.

Energy improvements in forming and post-forming operations tend to occur as byproducts of productivity improvements. The most significant opportunities for saving energy in forming processes are in increased productivity and in product lightweighting where practical.

The opportunity for direct energy savings in the textile and insulation fiber forming operations appears to be significant. Fiber formation consumes 20 to $40 \%$ of the total energy use of these processes. A large part of this energy is for remelting marbles prior to fiberizing. However, while conversion to direct fiberizing may result in energy savings in the glass fiber industry, it would likely be at the expense of increased energy use in the transportation sector since the final product is more bulky to ship than marbles. New fiber attenuation processes have been patented, but their energy savings potential 
has not been determined. We estimate that new fiberizing processes could save 2 to 5 trillion Btu/year in the long-term.

\subsubsection{Lightweighting}

Lightweighting refers to the use of progressively less-molten glass to produce a container having adequate strength characteristics. Lightweighting of glass containers has been underway since the 1950s (Southwick 1985). Most recently, interest in lightweighting has been in direct response to a desire to reduce process energy requirements and costs. Achievements in lightweighting have occurred through: 1) modification of the existing individual section (IS) machine and 2) the development of completely new forming machine concepts. Additionally, lightweighting progress has resulted from improvements in container design, glass surface chemical strengthening and glass surface protection via sprays and labels.

Adaptions to the current IS machine technology involve mainly the ability to produce beverage containers by the press-and-blow narrow neck process (NNPB) versus the traditional blow-and-blow method. The NNPB process adaptation has been developed by glass forming machine manufacturers such as Veba Glass (West Germany), Owens-Illinois, Hartford Empire, and Heye (Tooley 1984). The new IS machine developments are based on the concept of using two blow molds for every blank mold.

The only machine using this concept to reach semicomercial production is the Heye $\mathrm{Hl}-2$ machine. Weight reductions up to $30 \%$ are claimed as well as improved container strength and increased production efficiency (pack ratios). This machine produces both narrow neck and wide mouth containers.

The Heye process has already been licensed in 11 countries and the company has now decided to make its technology available to the entire international hollow glassware industry (Glass industry June, 1985). The pressure of increased energy and labor costs and the required productivity increases necessary to remain competitive in the container/packaging industry have all required development and adoption of such new lightweighting technology in the hollow ware industry. 
Another proposed method of container lightweighting is the laminated container process. In the process, a glass ribbon is fed into a machine together with special adhesives to form the container. The laminated container is stronger than containers formed by conventional means and therefore it offers an opportunity for lightweighting. Another advantage of this process is that the glass ribbons could be manufactured at a centrai facility and shipped to forming machines located at the point of use. This would avoid the transportation of empty containers (Berg 1982).

In general, bottles of the same capacity and shape that are produced by the same method decrease in strength as the amount of glass per unit is reduced (Osborne 1982). Chemical-strengthening technology and container surface protection techniques play an important role in maintaining container strength with lighter-weight containers.

A mixture of potassium salts sprayed on the interior and exterior surfaces of the container after annealing provides surface protection. Labels and protective wraps can reduce or eliminate glass surface damage. Specially designed low-friction contact materials can be used in the conveyance lines of the postforming operation to reduce initial surface damage and to maintain the initial high strength of a newiy formed container (Southwick 1985).

There has also been a trend toward the production of thinner tempered flat glass products. The production of thinner tempered glass tends to increase power consumption in the quenching process. Greater volumes of air are required with thinner products. For example, blower-powered systems for $3.2 \mathrm{~mm}$ glass require 1.9 times as much pressure, 1.4 times as much airflow and 2.6 times as much power as a system for $4.0 \mathrm{~mm} \mathrm{glass}$ of the same length and width (McMaster 1984). Variable-speed fan drives used in place of the inlet vanes used with standard quench systems can reduce blower system power consumption by 45 to $50 \%$ (Cuffle and Hammond 1985). 
Energy-Savings Potential

Weight reductions of up to $30 \%$ are reported for the commercialized Heye H1-2 forming process (Heather 1982, Tooley 1984). This percentage weight reduction results in a similar percentage reduction in melting energy use per unit of production.

The Iaminated container process is not commercially available. No estimates of its energy-savings potential have been made. EPRI (1982) estimated that the weight of larger volume beverage containers could be reduced by as much as $75 \%$ using this process. However, the specific energy savings resulting from this process would not be proportional to the decrease in container weight. This decrease would be mitigated by the need for higher melting temperatures to produce the high-quality ribbon needed in the process.

Protective coatings reduce energy consumption indirectly by allowing lightweight containers to be manufactured and by increasing the productivity of the process (reducing wasted product). Lightweighting has been shown to save melting energy by reducing the amount of glass required per container.

We estimate near-term savings of 4 to 6 trillion Btu/year, with long-term savings of 9 to 18 trillion Btu/year.

\section{Possible Barriers}

Adequate investment capital and a sufficient return on investment are required to implement the new Is technology. Barriers to the laminated container process include: 1) Stricter product quality requirements may exceed the limits of conventional glass melting practice, and 2) It is unlikeiy that the cullet from laminated containers could be recycled due to the presence of adhesives and resins.

The capital and operating costs of thin glass air quenching systems are higher than those for thicker glass products. Noise problems also increase with increased air blowing. The advantages of a variable-speed fan drive are more easily justified in a new tempering system rather than a retrofit. 


\subsection{PROCESS CONTROL}

Process control consists of three basic elements: 1) sensing and detecting equipment, 2) signal transmission and conditioning equipment, and 3) actuators and controllers (Energetics 1985). This section discusses the state of the art of each of these elements in a generic sense and provides a discussion of specific process control applications that save energy.

\subsubsection{Direct Digital Control}

Process control systems vary widely in the glass industry. In general, prior to the introduction of computer control, the glass industry relied on analog instrumentation and strip recorders. Furnace temperature readings were taken manually using optical pyrometers and thermocouple data. The air-to-fuel ratio was adjusted on the basis of exhaust gas samples taken about every two days. Because of the lag time inherent in manual sampling and control techniques, furnaces were run hotter than required to maintain a margin of safety in the operation (Nixon 1982). Excess fuel beyond what is theoretically required for melting was combusted to provide this conservative safety margin.

The first computer control systems used analog instrumentation and centralized control. Since the adoption of these first computer control systems, many process control technology improvements have occurred. The most dramatic improvements have been in signal transmission and conditioning equipment, which modifies the signal from the sensing equipment into a form usable by the controller, and in actuators and controllers, which receive the signals and use them to adjust process parameters. Currently state-of-the-art control systems use direct digital control (DDC) and distributed mini- or micro-processors.

The fiberglass industry was the first to adopt digital control and the float glass industry followed closely behind. The container glass industry has lagged behind these two in adoption of digital control due to the unsteady conditions caused by alternating regenerative furnace firing and intermittent job changes (Finger 1978) and because of investment payback policy.

Energy-Savings Potential

Direct digital control offers significant energy savings opportunities, particularly when applied to fossil-fired or electric melting. It is reported 
that based on previous experience, digital control of various aspects of glass melting can potentially save the following (Finger 1978):

1. glass temperature control (2-7\% fuel savings)

2. air/fuel ratio control (1-3\% fuel savings)

3. regenerator temperature control (1-2\% fuel savings).

\subsubsection{Oxygen Monitoring}

The development of the high-temperature oxygen sensor in the 1970 s has allowed furnace operators to more closely monitor the combustion process and excess air levels in their furnaces. Hoskins (1981) and Peckingham (1985) describe the use and advantages of oxygen monitoring and process control. 0xygen monitoring equipment in conjunction with automatic control is only useful if the sensors are placed in a location where meaningful oxygen readings can be obtained. These areas are high-temperature, corrosive environments.

\section{Energy-Savings Potential}

The actual energy savings depends on the performance of the furnace to be instrumented. However, Hoskins (1981) reported an average of $7 \%$ energy savings on Corning's large furnaces.

\section{Possible Barriers}

The rigorous environment in which the sensor must operate leads to high failure rates. Corning found the payback to be acceptable, despite the fact that the sensors have to be replaced about once every six months. Some companies have not installed them because they are waiting for a more reliable sensor to be developed or they are considering switching to an electric furnace. In any case, the installation of the oxygen monitoring system would probably have to wait for a rebuild.

\subsubsection{The Superflue (a) Regenerator Flow Controller}

Most of the conventional regenerators in the United States are not compartmented and the combustion air and exhaust gas flows through the regenerator

(a) Superflue is a registered trademark and patented system of Toledo Engineering Co. Inc., Toledo, Ohio. 
are uneven. Figure 4.9 shows the flow pattern in a conventional regenerator. This leads to local overheating of one part of the regenerator along with under-utilization of another part of the regenerator. The Superflue system consists of a series of manually positioned control dampers that produce an even flow of both exhaust and combustion air through the regenerator. The result is better overall performance and life of the regenerator. The Superflue shown schematically in Figure 4.10 , is a development of Toledo Engineering Company of Toledo, Ohio.

\section{Energy-Savings Potential}

Toledo Engineering has reported $12 \%$ melter energy savings on retrofit applications and $17 \%$ energy savings have been achieved in new Superflue ${ }^{\circledR}$ applications (Naveaux 1982).

\section{Possible Barriers}

The Superflue system can only be installed during a furnace rebuild or on new furnaces. While no general cost data for the Superflue are available, the payback of the system will have to meet industry requirements.

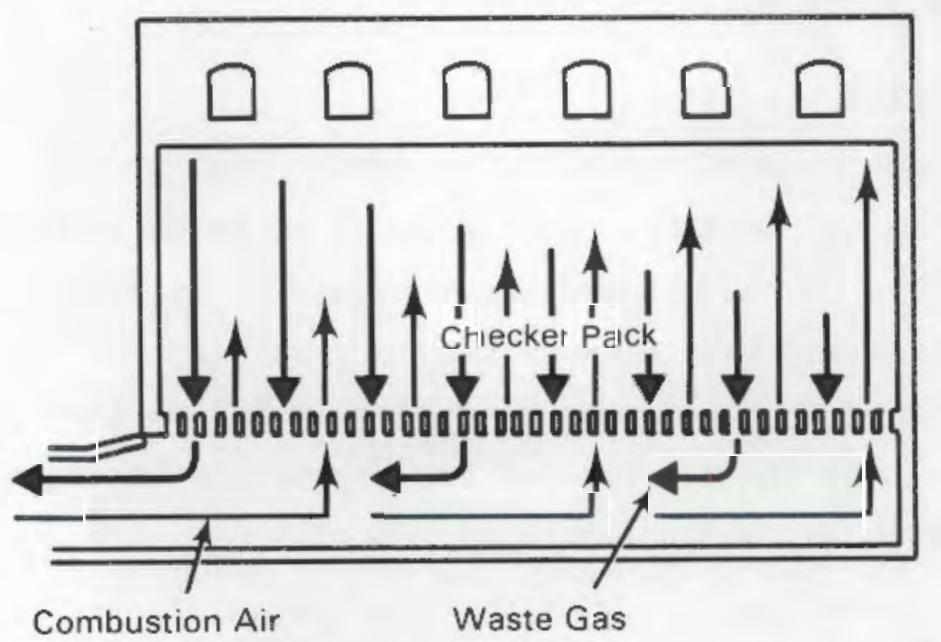

FIGURE 4.9. Flow Pattern in a Conventional Regenerator (Toledo Engineering Company) 


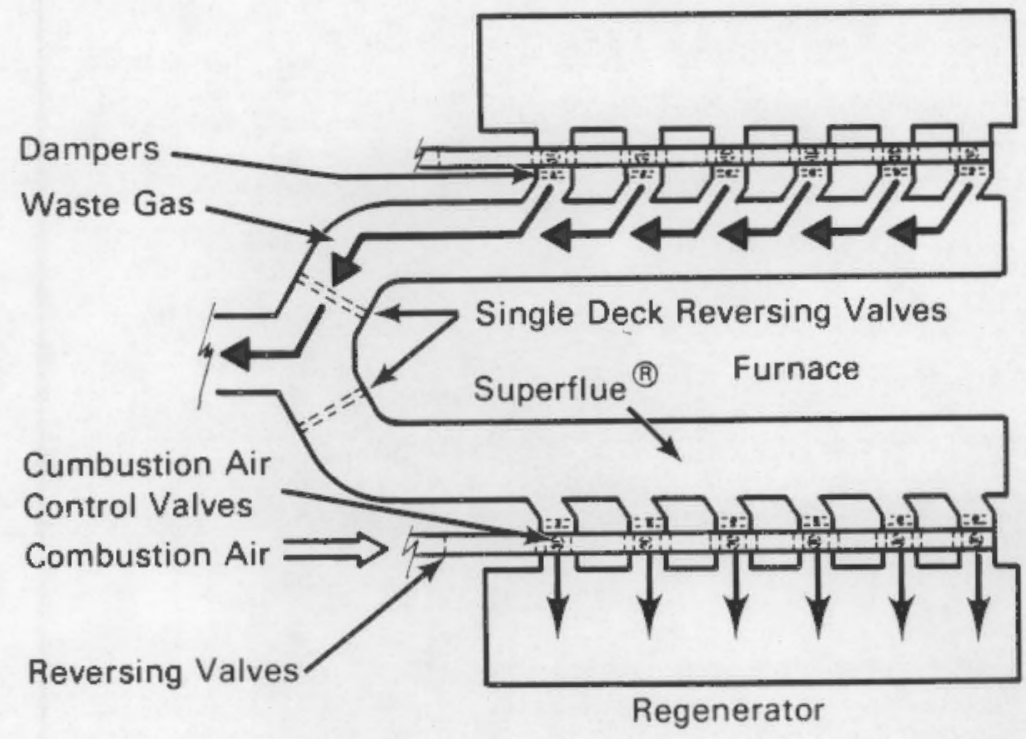
FIGURE 4.10. Superflue System (Toledo 
. 


\subsection{RESEARCH AND DEVELOPMENT OPPORTUNITIES}

This chapter provides a discussion of research and development (R\&D) opportunities which are thought to have the greatest potential to reduce the energy consumption of the glass industry.

Because meiting is the most energy-intensive unit operation in glass production and because some furnaces use as much as four times the energy theoretically required, the most significant opportunities to reduce energy consumption are related to melting.

\subsection{PRIVATE SECTOR RESEARCH}

A] though the most significant opportunities for reducing energy consumption are related to melting, glass manufacturers are unlikely to undertake long-term technical efforts in basic technology development which would lead to energy savings alone. Energy conservation will most likely occur as a secondary benefit of a technology developed to improve productivity.

Equipment manufacturers and glass producers have ongoing research programs which directly address the productivity of forming processes and product weight because these two areas impact not only energy costs, but the costs of labor and raw materials as well. The latter two may account for as much as $85 \%$ of a plant's direct costs (Edgington 1984).

Glass manufacturers and equipment developers have directed their research efforts in forming technology toward 1) development of new high-speed forming processes, 2) mold design and mold cooling system development, 3) wearresistant materials for metal components, 4) improvements in gob feeding, shearing, shaping, and weight control, and 5) computer control of forming processes.

International Partners in Glass Research (IPGR), which consists of a U.S. container glass manufacturer (Brockway, Inc.), a U.S. supplier of glass forming equipment (Emhart Corp.), and five foreign glass manufacturers, has undertaken a $\$ 5$ million, three-phase R\&D project aimed at developing a container that is 10 times stronger and half the weight of current designs. Phase 1 is to 
conduct basic research at leading universities (MIT, University of Florida, Case Western Reserve and Aifred University in the U.S.). This research includes investigating materials (including sol-gel coatings and glass-ceramic composites), modeling glass-forming processes, developing techniques to improve surface characteristics during forming, and investigating techniques to protect glass container surfaces during post-forming operations. Phase 2 will test the economic and technical feasibility of any developments emanating from Phase 1. Phase 3 will involve product and process development. It is expected that any new technology developed in this program will be made available to other manufacturers under a licensing agreement (Glass Industry Apri1 1985).

\subsection{RESEARCH AND DEVELOPMENT OPPORTUNITIES}

In general, advanced technologies that appear to have the greatest nearterm energy-savings potential are oxygen enrichment, glass batch preheating, improved refractories, improved regenerators, and computerized control systems.

\subsubsection{Incremental Opportunities}

The major barrier to the widespread adoption of these technologies is cost. Since the cost of energy is relatively small in comparison to material and labor costs, energy savings alone are not always a sufficient incentive for investment. Those technologies which also save labor or improve the productivity of the process stand a greater chance of implementation when evaluated against the industry's investment criteria (i.e., usually a one to two year payback). Further technology development to achieve cost reductions would greatly speed the deployment of these technologies.

\subsubsection{Dxygen Enrichment}

Oxygen enrichment of combustion air is a recognized means of saving energy and of extending the life of old furnaces. The major barrier to its widespread adoption is the cost of currently available oxygen generation equipment. Continuing current efforts to develop low-cost oxygen enrichment technologies appears to have great potential for overcoming this barrier. The impact of higher combustion temperatures on furnace refractories will need to be investigated. 


\subsubsection{Batch Preheating}

Further investigation of both direct and indirect batch preheating technology is needed. Specifically, systems which can accommodate preheating both loose batch and cullet together need to be developed to take full advantage of the energy-savings potential associated with this practice. Efforts to reduce the cost of the equipment must be undertaken to encourage adoption of this technology. In addition, system analys is of this technology in combination with other technologies such as cogeneration should be undertaken.

\subsubsection{Improved Refractories}

U.S. industries have developed high-quality refractories. However, these high-quality refractories are costly for widespread application. R\&D aimed at reducing the costs of refractories to make them economically feasible in more applications is regarded as a major opportunity for energy savings. Hightemperature refractories allow the use of greater amounts of insulation without the problem of refractory wear and associated glass quality degradation. In addition, the availability of low-cost, high-quality refractories will be necessary to allow widespread use of oxygen enrichment and electric furnaces.

\subsubsection{Revolutionary Opportunities}

Technologies which represent a radical departure from current glass production technology could have a significant impact on the industry's energy productivity. These technologies are typically in the conceptual or early development stages. Realizing the long-term conservation potential will require basic and applied basic research to determine the technical and economic feasibility of various technologies.

Revolutionary technologies which are identified as having significant potential include successful development of an advanced glass making and advanced recuperators. In addition, development of recuperators, cogeneration systems, and automatic control systems, which are considered state of the art in other industries, is impeded by a lack of materials capable of withstanding the highly corrosive, high-temperature glass furnace environment. 


\subsubsection{Advanced Melting Concepts}

Advanced melting concepts, which address the separate rate-limiting operations that occur in the conventional glass furnace, are in the very early research stages. Further proof-of-concept experiments are needed to verify the feasibility of suspension melting, batch liquefaction and sonic refining. In addition to the concepts currently proposed, other potential concepts should be developed and tested for performing batch liquefaction, batch grain dissolution, melt homogenization and glass refining. Proof-of-concept experiments must be followed by development and testing of pilot-scale prototypes. Attention must be given to both the capital and operating costs of advanced melting systems in order to make the concept acceptable to the industry.

\subsubsection{Chemical Processing}

Forming glass via a predominately chemical process rather than a thermal process represents a radical departure from conventional glass making practice. The sol-gel process has been under investigation for the past 25 years in more than 40 laboratories in the United States, Japan, France, and West Germany. Scientists have been attempting to develop techniques to avoid the cracking and granulation problems associated with glass formed by this process. Researchers at the University of Florida, Gainesville have recently reported success with a drying control chemical additive in laboratory tests.

Much development work is needed before a chemical process could be used to form common commercial glasses. The successes at laboratory scale must be demonstrated at a larger scale and the energy balance of the process and the economics need to be assessed. At this point, it appears that the energy required to refine the chemicals needed for the sol-gel process may offset any energy savings that may accrue from the process. The first applications of this technology will likely be for specialty glasses and new glass formulations that cannot be produced with current technology. Developing this technology for large-scale production of common glass products represents a long-term, high-risk opportunity. 


\subsubsection{Advanced Recuperators}

The glass industry exhausts between 1.0 and 1.4 quads of waste heat in flue gases each year (Wilfert 1984). Thus, the potential energy savings from a sustained recuperator R\&D program could have a large impact on this wasted resource. Both advanced thermal and thermochemical recuperators offer potential savings above current technologies. To improve the state of the art of recuperator technology, a long-term R\&D effort is needed to:

1. develop and test new recuperator designs with the goal of improving effectiveness over current technologies

2. identify and test materiats for high-temperature, corrosive service which will lengthen the useful life of recuperators and allow higher preheat temperatures to be achieved

3. andyze fouling and corrosion mechanisms and develop practical solutions to mitigate these problems.

Basic technical issues which need to be addressed with respect to thermochemical recuperator technology include the effect of the water/gas shift reaction, soot formation, and other side reactions on the ultimate heating value of the product fuel. At this point, only feasibility studies have been conducted. A proof-of-concept thermochenical recuperator should be developed and tested.

Systems studies are needed to analyze the impact of this technology on glass furnace operation and to analyze its operation in combination with cogeneration or other heat recovery technologies.

\subsubsection{Cogeneration}

The exhausts from typical U.S. glass plants are highly corrosive, and laden with particulate. As with recuperators, this acts as a barrier to the implementation of waste heat boilers for steam generation. Research is needed to understand fouling and corrosion mechanisms experienced in this type of equipment in order to develop appropriate means of mitigating these problems. In addition, exhausts from regenerators are cyclic in both temperature and flow 
rate, which is not amenable to the efficient use of current bottoming cycle technology. R\&D could be undertaken to develop a system that could operate efficiently in a cyclic environment.

\subsubsection{Advanced Sensors And Process Control}

The glass industry has been adopting computerized control, particularly in batch preparation, forming and post-forming, and product handling operations. Computerized control of the melting process is advancing more slowly due to the relatively short life of sensors in the severe operating environments associated with the furnaces. R\&D is needed to develop highly reliable temperature and oxygen sensors that can withstand this high-temperature, corrosive atmosphere.

An underlying factor contributing to the lack of quantitative understanding of the melting process is the inability to obtain reliable, quantitative measurements within the melter system. Sensor development would be a valuable component in mathematical modeling of melter behavior. In the long-term, reliable sensors could contribute to meaningful control systems for comercial melters.

\subsubsection{Mathematical Modeling}

A11 of the energy-conserving technologies interact directly or indirectly with the melting process. Their adoption may change the time, temperature, or shear history of the melt. While it is recognized that certain process variables (e.g., combustion temperature, natural convection currents in the glass, and batch blanket coverage) have a significant effect on glass quality and process energy use, they are only understood in a qualitative sense. To support technology development, research is needed to develop mathematical models of the melt space and the combustion space and of the complex interactions between the two. In the near-term, modeling of the combustion space and of energy recovery technologies could be combined to predict system behavior and to optimize technology combinations. In the long-term, melt space modeling could provide a predictive tool for analyzing the impact of technology change on glass quality. 


\section{REFERENCES}

Ahmed, A. A. and A. F. Abbas. December 1984. "Does Blast Furnace Slag Improve Glassmaking?" Glass Industry. 65(12):15-18. Ashlee Publishing Company Incorporated, New York, New York.

Anon. February 1985. "New Forehearth Design Reduces Energy Usage." Ceramic Industry. 124 (2). Cahners Publishing Co.

Anon. February 1985. "World's Most Prolific Bottle Former." Glass Industry. 65(2). Ashlee Publishing Company, Inc., New York, New York.

-..-. April 1985. "New Bushing Helps Improve Glass Microfiber Production Efficiency." Glass Industry. 66(4). Ashlee Publishing Company, Inc., New York, New York.

Arrandale, R. 1984. "Furnaces, Furnace Design and Related Topics." In The Handbook of Glass Manufacture. F. V. Tooley (ed), Ashlee Publishing Company, Inc., New York, New York.

Battelle Columbus Laboratories and Pacific Northwest Laboratories. 1977 . Survey of the Applications of Solar Thermal Energy Systems to Industrial Process Heat, Volume 2 - Industrial Process Heat Survey. Columbus, Ohio.

Berg, C. A. 1982. Industrial Electrification Potential: Case Studies of the Primary Metals and Glass Industries. EPRI-EA-2761. Prepared for the Electric Power Research Institute, Palo Alto, California.

Bony, P. November 1983. "Flue Gas Heat Recovery in Glass Furnaces." Glass. Societe Europeenne des Produits Refractaires (SEPR), Paris, France.

Bony, P. and P. Dreno. March 1983. "Heterogeneity in the Distribution of Gases in Regenerator Packings." G1ass International. SEPR, Paris, France.

Bowman, E.W., Inc. 1985. "Lehrs by Bowman." (Brochure) Uniontown, Pennsylvania.

Bowman, E. W., Inc. 1985. "The Bowman Bonus: Optimum Energy Efficiency." (Brochure). Uniontown, Pennsylvania.

Boyum, W. B. August 1982. The Brayton Cycle Gas Turbine for Industrial Furnace Waste Heat Recovery Applications. MITRE Corporation, McLean, Virginia.

Brown, J.R. November 1982. "Batch Briqueting - A Production Trial." $43 r d$ Conference on Glass Problems. Ohio State University, Columbus, Ohio.

Bureau of the Census. 1982. Fibrous G1ass. MA32J(82)-1. U.S. Department of Commerce, Washington, D.C. 
Bureau of the Census. 1983. Consumer, Scientific, Technical and Industrial Glassware. MA32E(83)-1. U.S. Department of Commerce, Washington, $0 . C$.

Bureau of the Census. December 1984. Flat Glass, Current Industrial Report. MQ32A(84)-3. U.S. Department of Commerce, Washington, D.C.

Bureau of Industrial Economics. 1984. 1984 U.S. Industrial Outlook. U.S. Department of Commerce, Washington, D. C.

Burwe11, C. C. September 1983. "Going the Electric Route in Glassmaking." Glass Industry. 64(9). Ashlee Publishing Company, Inc., New York, New York.

Carroll, H. R. and J. J. Ange10. November 1983. "Adding Lithium Can Improve Melting Performance." Glass Industry. 64(11). Ashlee Publishing Company, Inc., New York, New York.

Census of Manufactures. 1982. Fuels and Electric Energy Consumed. MC82-S-4. U.S. Department of Commerce, Washington, J.C.

Census of Manufactures. May 1984. Minera1 Wool, Preliminary Report Industry Series. MC82-1-32E-5(P). U.S. Department of Commerce, Washington, D.C.

Census of Manufactures. July 1984. Glass Containers, Preliminary Report Industry Series. MC82-I-32A-2(P). U.S. Department of Commerce, Washington, D.C.

Census of Manufactures. July 1984. Flat Glass, Preliminary Report Industry Series. MC82-I-32A-1(P). U.S. Department of Commerce, Washington, D.C.

Census of Manufactures. August 1984. Pressed and Blown Glass, N.E.C. Preliminary Report Industry Series. MC82-I-32A-3(P). U.S. Department of Commerce, Washington, D.C.

Census of Manufactures. 1985. Giass Products. U.S. Department of Commerce, Washington, D.C.

Clark-Monks, C. and M. C. Reynolds. December 1980. "The Electric Forehearth and its Energy Requirements." Glass Technology. 21(12) King, Taudevin \& Gregson Ltd., Great Britain.

Cole, W. E., C. Joshi and J. Griffith. February 1983. Glass Batch Preheater, Final Report Phase III, Gas Research Institute, Available NTIS, ThermoElectron Corporation GRI-82/0001.3

Cozzi, C., P. Blanchet and J. Segond. March 1980. "The Furnace Throat and Its Functions." Glass International. SEPR, Paris, France.

Cuffle, S. S. and P. W. Hammond. June 1985. "Variable Speed Blowers Improve Operating Efficiency." Glass Industry. 66(\&):30-32, 36. 
Darbon, M., R. Laffont and R. Moreau. September 1983. "Contribution of Cruciforms to the Improved Performance of a Container Glass Furnace." Glass International. B. N. Emballage.

Davis, D. H. and D. H. Davies. February 1983. "Solving The End-Port Charging Problem." Glass Industry. 66(4). Ashlee Publishing Co., Inc., New York, New York.

Delrieux, J. August 1980. "The Influence of the Thermal Properties of Refractories and Their Mode of Utilization of the Heat Balance in Regenerators." Giass Technology. 21(4). SEPR, Paris, France.

Demarest, Jr., H. M. May 28, 1985. Two Stage Batch Liquefaction Process and Apparatus, U.S. Patent 4,519,814.

Denniston, D. W. 1985. "Waste Heat Recovery in the Glass Industry." Industrial Heat Exchangers. American Society for Metals Conference Proceedings, Pittsburgh, Pennsyivania.

Douglas, R. J. July 1983. "Improving Glass Container-Manufacturing Productivity." Glass Industry. 64(7). Ashlee Publishing Company, Inc., New York, New York.

Doyle, E. F. and L. W. Donaldson, Jr. 1984. "Glass Batch Preheating Utilizing Fiuidized Bed Technology." 1984 International Gas Research Conference Proceedings, Gas Research Institute, Thermo-Electron Corporation.

Doyle, E. F. and L. W. Donaldson, Jr. 1985. "Batch Preheating Via Fluidized Bed Offers Improved Melter Operation." Glass Industry. 66(8):18,23-25,35. Ashlee Publishing Company, Inc., New York, New York.

Edgington, J. H. 1984. "How the Glass Container Industry Can Improve Its Profitability." Glass Industry. 65(4):14-20.

Elder, H. April 1985. "Glass Makers Look to Fibers to Reinforce Their Future." Chemical Business. 7(4). Schnell Publications.

Energetics, Incorporated. May 1985. Industrial Process Control R\&D Needs Assessment. Prepared for the U.S. Department of Energy, Washington, D.C.

Finger, T. H. October 1978. "Digital Control - Mini and Micro Computers in Glass Melting." IEEE-IAS 13th Annual Meeting. New York, New York.

Foley, P., H. Cox and W. Word. March 1984. "How Electric Melting Affects Glass Chemistry." Glass Industry. 65(3). Ashlee Publishing Company, Inc., New York, New York.

Foster, T. V. December 1983. "Efficient Blow Mould Cooling." Glass International. Emhart, United Kingdom. 
Fuller, R. A. 1975. "Lehr Design for Energy Conservation." Ceramic Bullet in. $54(3): 277-279$.

Gavaghan, H. April 1985. "Taking the Heat Out Of Glass Making." New Scientist.

Glass Industry. January 1985. "Flat Glass Industry Outlook." 66(1):14-15. Ashlee Publishing Company, Inc., New York, New York.

Glass Industry. Apri1 1985. "International Consortium Attacks the LightWeighting Problem." 66(5):23. Ashlee Publishing Company, Inc., New York, New York.

Glass Industry Directory Issue. 1985. 66(3). Ashlee Publishing Co., Inc. New York, New York.

Glass Reflections. March 1985. "AFG's Cunningham Foresees 'Softer Landing, Firmer Ground'." Monthly News Service of the Flat Glass Marketing Association, Topeka, Kansas.

Haggin, J. July 22 1985. "Alternative Heat Recovery Based on Methane Reforming." Chemical and Engineering News. p. 26-27.

Haines, D. M. February 1977. The Use And Conservation of Natural Gas in the Glass Industry. Prepared for American Gas Association by Dynatech R/D Company.

Harper, (INITIALS), et al. February 1982. "The Economics and Practicality of a Change to Coal as an Energy Source for Glass Making." Glass Technology. 23(1): $44-51$.

Hench, L. L., S. H. Wang, and S. C. Park. 1985. Si0, Gel Glasses. Department of Materials Science and Engineering, University of Florida, Gainesville, Florida.

Heather, R. P. January 1982. "Glass Container Manufacturing Technology Developed to Provide Cost Reduction and Energy Conservation." Journal of Non-Crystalline Solids. 52. North Holland Publishing Company, Heye Glass.

Heye, I. A. June 1977. "A Proportional Burner for Firing Gas and 0il Glass." Glass. 54(6):216-217. Fuels and Metallurgical Journals Ltd., Surrey, England.

Hibscher, C. 1982. "The First Campaign of a Cold Top Electric Furnace." 43 rd Conference on Glass Problems. Ohio State University, Columbus, Ohio.

Hnat, J. G. and W. F. Coles. March 1984. "Will Cogeneration Work on a Regenerative Furnace?" Glass Industry. 65(3). Ashlee Publishing Company Inc., New York, New York. 
Hoskins, J. W. and A. M. Chirino. March 1981. "Controlling Excess Oxygen in Glass Furnaces for Energy Conservation." IEEE Transactions of Industry Applications. IA-17(2). IEEEPID 80-81.

Howard, R. December 1983. "Trends in Domestic Pressware Forming." Glass International. Lynch Machinery Division, Anderson, Indiana.

Hunt, T. K., and N. Weber. February 1982. "The Sodium Heat Engine: A New Approach to Direct Thermal-to-Electricity Conversion." Proceedings of the 9 th Energy Technology Conference and Exposition. Washington, D.C.

Hunter, D. and X. Brooks. April 1985. "A New French Route to Glass Production." Chemical Week. Vol. 136. McGraw-Hi11, Rhone-Poulenc.

Jeanvoine, P. and P. Bony. March 1984. "Vanadium in Heavy Fuel 0ils Used For Glass Furnaces: Influence On The Durability of Regenerator Packing." Glass International. SEPR, Paris, France.

Kirk-0thmer Encyclopedia of Chemical Technology. Third Edition. Wiley, New York, New York.

Klepper, M. May 1984. "Capturing Energy Savings Without any Capital Investment." Glass Industry. 65(5). Ashlee Publishing Company Inc., New York, New York.

Kunkle, G. E. and J. M. Matesa. May 3, 1983. Glass Batch Liquefaction. U.S. Patent $4,381,934$.

Llewellyn, G. and G. C. Wei. November 1982. Thermal Analysis and Air Leakage Evaluation of a Typical Container-Glass Furnace with a Brayton Cycle Heat Recovery System. ORNL/TM-8429. Oak Ridge National Laboratory, Oak Ridge, Tennessee.

Lofquist, W. 1984. "The Outlook for Glass Containers." Glass Industry. 65(1):16-18,30. Ashlee Publishing Company, Inc. New York, New York.

McGinty, R. F. 1985. "Molding Instant' Glass with a Sol-Gel Mixture." Chemical Week. March 20, 1985.

Mclellan G. W. and E. B. Shand. 1984. Glass Engineering Handbook. McGrawHi11 Book Company, New York, New York.

McMaster, R. A. 1984. "How Glass Tempering Practices Affect Product Quality." Glass Industry. $65(6)$.

McMaster, R. A. 1985. "Electrically Heated Furnaces Used in Glass Tempering Systems." Industrial Heating. LII(4):46-48.

Miller, R. K. 1982. Energy Conservation and Utilization in the Glass Industry. The Fairmont Press, Inc. 
Moreau, J.C., C. Cozzi and P. Bony. December 1984. "Behavior of Cruciform Regenerator Packing In An End-Fired Furnace: Practical Results After One Campaign." Glass International. Tourres et Co.

Moreau, R., P. Jeanvoine and A. Westgate. June 1981. "Fused-Cast Refractories and Campaign Duration of Hollow Ware Glass Furnaces." Glass International. SEPR, Paris, France.

Muschalla, B. P. April 1985. "The Distribution Chamber Concept." Glass Industry. 66(5). Ashlee Publishing Co., Inc., New York, New York.

Naveaux, R. J. and J. J. Shea. February 1982. "A Method For Improving Regenerative Furnace Efficiency." The Glass Industry. Toledo Engineering, Toledo, Ohio.

Neff, G. Jr. January 1985. "Fuel Saving Burner Practices for a Regenerative Glass Furnace." Proceedings 87 th Meeting of the American Ceramic Society. American Ceramic Society, New York, New York.

Nelson, F. J., and R. S. Richards. May 1985. Waste Heat Recovery From Regenerative Furnaces. U.S. Patent $4,516,934$.

Nixon, S. S. 1982. "Recent Experience with Digital Process Control for a Glass Furnace and Forehearths." American Ceramic Society Bulletin. 61(12): 1290-1291.

Oak Ridge Associated Universities. 1980. Industrial Energy Use Data Book. ORAU-160. Oak Ridge, Tennessee.

Office of Industrial Programs. April 1985. Annual Report to Congress and the President on Industrial Energy Efficiency Improvement 1983. DOE/CE-0015/4. U.S. Departiment of Energy, Washington, D.C.

Osborne, D. G. 1982. "The Relationship Between Melting Energy and Glass Container Design." Glass Technology. 23(5):230-234.

Palnquist, R. W. July 1984. "Corning Develops a Moly-Lined Melter." Glass Industry. 65(7). Ashlee Publishing Co. Inc., New York, New York.

Penberthy, L. 1984. "Electric Melting of Glass." In The Handbook of Glass Manufacture. F. V. Tooley (ed.), Ashlee Publishing Co., Inc., New York, New York.

Perry, R. C. February 1984. "The Float Glass Process: A New Method or an Extension of Previous Ones." Glass Industry. 65(2). Ashlee Publishing Co. Inc., New York, New York.

Pollock, K. A. 1984. "A Revolution in Glass Making - A Unit Operations Approach." PPG Industries, Inc., Pittsburgh, Pennsylvania. 
Power, D. 1980. Ceramic Materials Selection for a Glass Furnace Recuperator. 0096-736x/80/8801-0860. Society of Automotive Engineers, Inc.

Richards, R. S. December 1984. Method of Sealing Glass Furnaces to Prevent Air Leakage. U.S. Patent 4,487,621.

Ross, C. P, 1982. "Operational Evaluation of the Dual-Glass-Depth Melting Concept." 43rd Conference on Glass Problems, Ohio State University.

Scheiblechner, G. October 1982. "Veitscher Chimney Type Checker Block Packing Method for Glass Tank Regenerators." Glass Technology. 23(5). Veitscher Magnesitwerke A. G.

Scheiblechner, G. August 1984. "The Case for Chimney Block Packing." Glass Industry. 65(8). Ashlee Publishing Company Inc., New York, New York.

Schorr, J. R. and G. A. Anderson. 1975. Industrial Energy Study of the Glass Industry. PB-242 832. Battelle Columbus Laboratories, Columbus, Ohio.

Schorr, J. R., et al. March 1977. Development and Establishment of an Energy Efficiency Improvement Target for SIC 32: Stone, CTay and Glass Products. Battelle Columbus Laboratories, Columbus, Ohio.

Seehausen, J. W. January 1984. "Radiation Recuperators - High Temperature Heat Recovery Units that Advance Thermal Processes." Industrial Heating.

Segond J. and G. Duvierre. April 1981. "Refractories and Glass Quality." Glass. SEPR, Paris, France.

Sohio Engineered Materials Co. October 1983. Monofrax Refractory Systems for Glass Furnaces. Form A-2668. Carborundum, Niagara Falls, New York.

Southwick, R. D. June 1985. "A Super-Light Bottle is Feasible." Glass Industry. $66(\&): 14-17$.

St. Clair, J. R. November 1984. "How High Quality Laminated Glass is Made." Glass Industry. 65(11). Ashlee Publishing Company Inc., New York, New York.

Stark, T. F. March 1985. "Recuperators on Unit Melters." Glass Industry. 66(4). Ashlee Publishing Co., Inc., New York, New York.

Steitz, W. R. and C. W. Hibscher. November 1980. "Design Considerations For Ali-Electric Melters." 41st Conference of Glass Problems Proceedings. Ohio State University, Columbus, Ohio.

Tooley, F. V. 1984. The Handbook of Glass Manufacture. Third Edition. Ashiee Publishing Company, Inc., New York, New York.

Ulmer, J. July 1982. "A Consideration of Annealing, Decorating and Multipurpose Lehrs." Glass International. E. W. Bowman Inc, Uniontown, Pennsylvania. 
Utsler, R. E. and C. P. Ross. April 1980. "Improving Giassmeiting Efficiency by Furnace Design and Operating Practices." Ceramics. 59(11). American Ceramic Society, New York, New York.

Van der Sijs, J. 1973. "Giass Heat Treatment Processing Equipment." Holectechniek. 3(3):121-127.

Vilk, P. March 1985. "Forehearth Field Performance." Glass Industry. 66(4). Ashlee Publishing Co., Inc., New York, New York.

Walker, G. E. July 1982. "Annealing Lehrs for Glass Containers." Glass International. Cobelconex, United Kingdom.

Webb, R. L. and A. K. Kulkarni. July 1982. Heat Exchanger Needs for Recovering Waste Heat in the Glass Making Industry. D0E/ID/12225-T1. Prepared for U.S. Department of Energy, Washington, D.C.

Wei, G. C., R. 0. Williams and G. H. Llewellyn. 1981. "Brayton Cycle Heat Recovery for Container-Glass Melting Furnace." Proceedings of the 16th Intersociety Energy Conversion Engineering Conference. American Society of Mechanical Engineers, New York, New York.

Westra, L. F. and L. W. Donaldson, Jr. 1986. "Development of an Advanced Gasfired Glass Melting System." Presented at the International Energy Technology Conference, March 1986, Washington, D.C.

Wetzel, F. R. October 1983. "Glass Melting the Auto-Tap Way." Glass Industry. 64(10). Ashlee Publishing Company, Inc., New York, New York.

White, J. B. January 1984. "Producing Flat Glass in the 21 st Century." Glass Industry. 65(1):20-21.

Wilfert, G. L., et al. May 1984. Characterization of Industrial Process Waste Heat and Input Heat Streams. PNL-4912. Prepared for U.S. Department of Energy, Washington, D.C.

Wood, A. S. July 1985. "Fine-Tuned Technology, Novel Whiskers, Fresh Commitments." Modern Plastics. 62(7). McGraw Hil1, New York, New York.

Wood, R. P. April 1985. "Improvement in Glass Melting Efficiency." Glass Technology. 22.

Yunker, R. W. 1984. "Flat Glass Manufacturing Processes." In The Handbook of Glass Manufacture. F. V. Tootey (ed), Ashlee Publishing Co., Inc., New York, New York. 
APPENDIX A

ASSUMPTIONS FOR ENERGY-SAVINGS CALCULATIONS 
APPENDIX A

ASSUMPTIONS FOR ENERGY-SAVINGS CALCULATIONS

\begin{tabular}{|c|c|c|c|c|c|}
\hline Technology & $\begin{array}{c}\text { Applicable } \\
\text { Sectors }\end{array}$ & $\begin{array}{c}\text { Applicable } \\
\text { Tonnage } \\
(\%) \\
\end{array}$ & $\begin{array}{c}\% \\
\text { Savings }\end{array}$ & $\begin{array}{c}\text { Annual } \\
\text { Savings } \\
\left(10^{12} \text { Btu/yr) }\right. \\
\end{array}$ & $\begin{array}{c}\% \text { of } \\
1985 \text { Use }\end{array}$ \\
\hline \multicolumn{6}{|l|}{ Chemical Boosting } \\
\hline near-term & a11 & 25 & $I-3$ & $0.1-0.3$ & $<1$ \\
\hline \multicolumn{6}{|l|}{ Chemical Processing } \\
\hline long-term & all & 50 & $20-30$ & $20-30$ & $5-8$ \\
\hline \multicolumn{6}{|l|}{ Purified Raw Materials } \\
\hline near-term & 3229 & 10 & $5-10$ & $0.2-0.3$ & $<1$ \\
\hline \multicolumn{6}{|l|}{ Advanced Burners } \\
\hline near-term & all & 10 & $3-5$ & $0.6-1$ & $<1$ \\
\hline \multicolumn{6}{|l|}{ Oxygen Enrichment } \\
\hline near-term & all & 100 & $10-15$ & $20-30$ & $5-8$ \\
\hline \multicolumn{6}{|l|}{ rilass Batch Preheating } \\
\hline \multicolumn{6}{|l|}{ Advanced Refining } \\
\hline long-term & a 11 & 50 & $5-10$ & $5-10$ & $1-2.5$ \\
\hline \multicolumn{6}{|l|}{ Improved Refractories } \\
\hline near-term & a!l & 50 & $5-10$ & $5-10$ & $1-2.5$ \\
\hline long-term & al1 & 100 & $5-10$ & $10-20$ & $2.5-5$ \\
\hline \multicolumn{6}{|l|}{ Advanced Regenerators } \\
\hline near-term & $3211,3221,3229$ & 75 & $3-7$ & $5-10$ & $1-2.5$ \\
\hline \multicolumn{6}{|l|}{ Arvanced Recuperators } \\
\hline \multirow{2}{*}{\multicolumn{6}{|c|}{ Cogeneration }} \\
\hline & & & & & \\
\hline long-term & a 11 & 25 & $20-30$ & $13-18$ & $3-5$ \\
\hline \multicolumn{6}{|l|}{ Lightweight ing } \\
\hline near-term & $3211,3221,3229$ & 15 & $10-15$ & $3-5$ & $1-1.5$ \\
\hline Tong-term & $3211,3221,3229$ & 30 & $15-30$ & $9-18$ & $2.5-4.5$ \\
\hline \multicolumn{6}{|l|}{ Advanced Fiherizing } \\
\hline long-term & 3229,3296 & 12.5 & $5-10$ & $2-5$ & $1-1.5$ \\
\hline \multicolumn{6}{|l|}{ Advanced Sensors/Controls } \\
\hline near-term & all & 100 & $3-7$ & $6-14$ & $1.5-4$ \\
\hline long-term & all & 100 & $5-10$ & $10-20$ & $2.5-5$ \\
\hline \multicolumn{6}{|l|}{ Advanced Melting Concepts } \\
\hline long-term & a 11 & 80 & $20-47$ & $50-75$ & $13-19$ \\
\hline
\end{tabular}




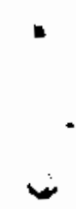

3 
No. of

Copies

OFFSITE

Mr. John Rossmeiss 1

U.S. Department of Energy

Office of Industrial Programs

Forrestal Building

1000 Independence Avenue, S.W.

Washington, D.C. 20585

Mr. Matthew J. McMonigle

U.S. Department of Energy

Office of Industrial Programs

Forrestal Building

1000 Independence Avenue, S.W.

Washington, D.C. 20585

30 DOE Technical Information Center

$\mathrm{Mr}$. Angelo Barberic

Xorbox Corporation

290 Creekside Drive

Tonawanda, NY 14150

Mr. Robert J. Cunningham

1487 Elmwood Drive

Lancaster, $\mathrm{OH} 43130$

Mr. Leslie Donaldson, Jr.

Project Manager, Nonmetals

Industrial Processes

Industrial Utilization Research

Gas Research Institute

860D West Bryn Mawr Avenue

chicago, IL 60631

Mr. Dean S. Doren

Chief, Furnace Design and

Development

LOF Glass

1701 East Broadway

Toledo, $\mathrm{OH} 43605$
No. of

Copies

Mr. Samuel E. Fuller

Process Development

Superintendent

PPG Industries Inc.

P.0. Box 800

Meadville, PA 16335

Mr. Albert F. Garrone, P.E.

Vice President

Henry F. Teichmann, Inc.

P.0. Box 11667

Pittsburgh, PA 15228

Mr. Terry E. Hartman

Design Engineering Supervisor

Libbey Glass

940 Ash Street

Toledo, $0 \mathrm{H} 43611$

Or. Bruce Hedman

Gas Research Institute

8600 West Bryn Mawr Avenue

Chicago, IL 60631

Mr. Carl Hibscher, P.E.

Manager of Commercial

Development

Toledo Engineering

3400 Executive Parkway

Toledo, $\mathrm{OH} 43606$

Mr. Anthony J. Masella

Technical Manager, Combustion

Liquid Air Corporation

$5230 \mathrm{~S}$. East Avenue

Countryside, IL 60525

Mr. Robert Meachem

Manager, Engineering and Electronics

Maul Technology

111 South 15th Street

Millville, NJ 08332 
No. of .

Copies

Dr. E. Kears Pollock

Di rector of Research, Glass

PPG Industries

Glass Research Laboratories

P.0. Box 11472

Harmar Twp.

Pittsburgh, PA 15238

Mr. H. Oavid Sigmund

Furnace Engineer

Anchor Hocking

2980 West Fair Avenue

Lancaster, $\mathrm{OH} 43130$

Mr. Charles M. Smith

Manager

Anchor Hocking

2980 West Fair Avenue

Lancaster, OH 43130

Mr. Thomas Stark MS/204

Manager Furnace Engineering

Building Materials Division

Manville Service Corporation

P.0. Box 5108

Ken-Karyl Ranch

Denver, C0 80217

Dr. William H. Thielbahr, Manager

Energy Conservation Branch

Energy and Technology

Division

U.S. Department of Energy

Idaho Operations of $f$ ice

550 Second Street

Idaho Falls, ID 83401
No. of

Copies

Mr. James Ulmer

President

E. W. Bowman, Inc.

P.0. Box 849

Uniontown, PA 15401

Mr. Morris E. Van Vooren

Chief, Furnace Engineering

Owens-Ill inois

P.0. Box 919

Toledo, $\mathrm{OH} 43693$

Mr. Ronald 0. Walton

Senior Furnace Engineer

LOF Glass

1701 East Broadway

Toledo, OH 43605

ONSITE

DOE Richland Operations Office

J. J. Sutey

39 Pacific Northwest Laboratory

W. B. Adams

M. Clement

J. H. Currie

A. G. Fassbender (10)

B. A. Garrett-Price (16)

N. L. Moore

R. W. Reilly

J. M. Roop

Technical Information Files (5)

Publishing Coordination (2) $\mathrm{MH}$ 